\title{
ALLOCATION OF LOSSES FROM CHECK FORGERIES UNDER THE LAW OF NEGOTIABLE INSTRUMENTS AND THE UNIFORM COMMERCIAL CODE*
}

THE allocation of forgery losses arising from the use of checks presents a difficult task for the courts. While the number of forged checks ${ }^{1}$ is small in relation to the total number of valid checks, ${ }^{2}$ the loss to the community is nevertheless substantial. The exact figures have never been authoritatively itemized, but the scope of loss is indicated by estimates that as much as $\$ 400,000,000$ annually is obtained by fraudulent check artists. ${ }^{3}$ Since funds which have been paid out to a forger frequently cannot be recouped, some legitimate member of the commercial community must bear the loss. The law of negotiable instruments determines who that member shall be.

Procedurally, the way in which the law allocates losses frequently involves a chain of recoveries among the parties associated with the check. Of course, the forger is always liable for the loss he causes. But where a forger is absent or unable to pay, innocent parties will bear the loss. The party who has taken the instrument from the forger, for example, may find that he is unable to cash the check because the forgery has since been discovered. ${ }^{4}$ Then

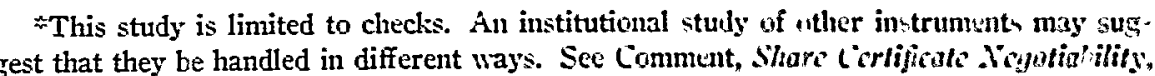
7 U. of CHI. L. Rev. 497 (1940).

1. Forgery as herein used includes the making of a false endorsement or drawer's signature, raising the face amount of the check, altering the named payee, or any combination of these.

2. Mrore than ninety-nine percent of checks circulating through the bank collecting system are finally paid. Asrerrcan LAw Instrtute \& Nat. Conf. of Cosinssioners 0: Uniform State Laws, Uniforar Conarercial Code, Official Draft 479 (tent and comments ed. 1952) (hereinafter cited as U.C.C.).

3. Reports on total losses vary considerably. Estimates uf $\$ 400,000,000$ are reported by Lloyd Wendt, Check Carefslly on that Check, Chicago Sunday Tribune Mlagzzine, IFarch 19, 1950, p. 5, and by Communication to Yule Law Jourane from George Adlam, Manager, Insurance Department, The Todd Co., dated Mfarch 27, 1952, on file in tite Yale Law Library. Other authorities set loss at $\$ 20,000,000$ annually-James E. Baum, The Big Plumin in Forgery, American Bankers Association Prutective Bulletin, Sept, 1950, p. 3-; or $\$ 500,000$ to $\$ 800,000$ annually-Note, 14 U. of Cur. L. REv. 705,709 (1947). In 1951 the Secret Service investigated 35,957 forged chcels worth $\$ 2,679,593.40$ and arrested 2,304 check and bond forgers. Communication to the Yale Law JoLroint from U. E. Baughman, Chief, U.S. Secret Service, dated Feb. 23, 1952, on file in the Yale Law Library.

4. "When a signature is forged or made without the authority of the persen whose signature it purports to be, it is wholly inoperative, and no right to retain the instrument, or to give a discharge therefor, or to enforce payment thereof against any party thereto, can be acquired through or under such signature, unless the party against whom it is sought to enforce such right is precluded from setting up the forgery or want of authority." Negortable Instruments LAw \$23. Edgington v. Security-First Nat. Banl: of Los 
he is left with a worthless piece of paper. However, he may have deposited the check for collection in a bank before the forgery was unearthed. If the collecting bank finds that it is unable to cash the check it will attempt to fall back for recovery upon the party who deposited the check. The collecting bank, however, may have already obtained payment from the bank on whom the check was drawn, i.e., the drawee bank. The drawee bank will try to debit the account of the person who drew the check, i.e., the drawer. ${ }^{0}$ When it is successful, loss shifts to the drawer. But if it cannot debit the account, the drawee may either be left with the worthless check $^{7}$ or it may have an action against the collecting bank. ${ }^{8}$ When the collecting bank must repay funds to the drawee, it can in turn fall back upon the party who negotiated the check

Angeles, 78 Cal. App. 2d 849, 179 P.2d 640 (1947) (forgery a defense against liability on check under NIL \& 23); Elyria Savings \& Banking Co. v. Walker Bin Co., 92 Ohio St. 406, 111 N.E. 147 (1915) (forged endorsement); Cowan v. Thompson, 25 Tenn. App. 130, 152 S.W.2d 1036 (1941) (forged drawer's signature).

5. The bank, if it has given cash or allowed the party to withdraw funds against the check, will have an action on the warranty accompanying negotiation "That the itstrument is genuine and in all respects what it purports to be; That he [the person negotiating the instrument] has a good title to it." NIL $\$ \S 65,66$. Frequently, however, the bank has an agreement with the depositor that checks are credited subject to final payment. Then when a check is returned unpaid, the bank has a right to charge back the item against the depositor's account. See cases cited notes 9 and 22 infra.

6. The drawee bank has a contractual relationship with the depositor to pay funds out of his account only according to his order. This may be an implied contract. Denbigh v. First Nat. Bank of Seattle, 102 Wash. 546, 174 Pac. 475 (1918). But many banlss have the following clause on the Depositor's Contract for checking accounts: "To (Name of Batuk). You are authorized to recognize any of the signatures subscribed below in the payment of funds or the transaction of any business for this account." Thus the bank would be able to debit the depositor's account only if the depositor were precluded from denying the forgery. See United States v. National City Bank of N.Y., 28 F. Supp. 144 (S.D.N.Y. 1939); Magid v. Drexel Nat. Bank, 330 Ill. App. 486, 71 N.E.2d 898 (1947); Connors v. Old Forge Discount \& Deposit Bank, 245 Pa. 97, 91 Atl. 210 (1914) : cases cited notes 16, 20, 40-3a infra.

7. This would occur, for example, when the drawee bank had taken the chcck from the forger, Hays v. Lowndes Savings Bank \& Trust Co., $11 \mathrm{~S}$ W. Va. 360, 190 S.E. 543 (1937) ; or was denied recovery from prior parties, see notes 17, 98 infra.

8. Recovery on check with forged indorsement: e.g., Farmers' Bank \& Trust Co. v. Farmers' State Bank of Brookport, 148 Ark. 599, 231 S.W. 7 (1921) ; Hartford-Connceticut Trust Co. v. Riverside Trust Co., 123 Conn. 616, 197 At1. 766 (1938) ; Furlong v. Manufacturers' Nat. Bank of Detroit, 285 Mich. 517, 281 N.W. 309 (1938); and cases cited note 21 infra. Recovery on check with forged drawer's signature: $c . g$, First Nat. Bank of Danvers v. First Nat. Bank of Salem, 151 Mass. 280, 24 N.E. 44 (1890); People's Bank v. Franklin Bank, 88 Tenn. 299, 12 S.W. 716 (1889); Canadian Bank of Commerce v. Bingham, 30 Wash. 484, 71 Pac. 43 (1902); cases cited notes 45, 142 infra. Recovery on altered check: e.g., Union Tool Co. v. Farmers' \& Merchants' Nat. Bank, 192 Cal. 40, 218 Pac. 424 (1923); Andrews v. Sibley, 220 Mass. 10, 107 N.E. 395 (1914) ; Trustees of German Evangelical Lutheran St. John's Congregation v. Merchants' Nat. Bank, 139 Minn. 80, 165 N.W. 491 (1917); and cases cited notes 32, 35 infra. 
to it. ${ }^{9}$ In some instances the check may have been stolen from its true owner. The true owner will usually have an action against the drawer of the checl: on any underlying obligation for which the check was given, ${ }^{10}$ or an action against any of the other parties associated with the instrument ${ }^{11}$ Occasionally the true owner will have no possibility of recovery and will bear the loss. ${ }^{12}$ Thus the law of negotiable instruments may ultimately place forgery losses on any of five parties: the taker from the forger, the collecting bank, the drawee bank, the drawer, or the true owner. ${ }^{13}$

\section{How the Law Allocates Losses}

The allocation of losses resulting from check forgeries stems from a comple: and interrelated body of statutory and case law. Basically, the law allocates losses among parties according to a set of mechanical doctrines that differ according to the type of forgery which prompted the loss. ${ }^{14}$ However, the introduction of negligence concepts to avoid placing loss on parties who exercised care, while others did not, frequently alters the allocation based on types of forgery. ${ }^{15}$ And the peculiar variance in the availability of some defenses in actions founded on check forgeries further changes the incidence of loss.

9. See National Bank of Detroit v. Fidelity \& Deposit Co. of Mrd., 391 Mich. 36,233 N.W. 325 (1939); Williams v. Tishomingo Savings Institution, 57 Miss. 633 (1830); Liberty MIutual Ins. Co. v. First Nat. Bank in Dallas, — Tex. —, 245 S.W.2. 237 (1951). For discussion of basis of recovery see note 5 stpro.

10. Shephard \& Morse Lumber Co. v. Eldridge, 171 MIass. 516, 51 X.E 9 (1893); Rettinghouse v. Krey Packing Co., 200 S.W.2d 5S4 (Mo. App. 1947); Falconi v. Magee, $47 \mathrm{~Pa}$. Super. 560 (1911) ; cases cited note 23 infra. But cf. note 30 infra.

11. Suit against drawee bank: c.g., Tarrant American Savings Bank v. Smolscless Fuel Co., 232 Ala. 507, 172 So. 603 (1937) ; cases cited note 24 infra. Suit against collecting bank: c.g., Universal Carloading \& Distributing Co. v. South Side Bank, 234 Mlo. App. 876, 27 S.W.2d 768 (1930) ; cases cited note 25 infro. Suit against an indorser subsequent to theft: e.g., Blum v. Whipple, 194 Mfass. 253, 80 X.E. 501 (1907); cases cited note 26 infra.

12. Louisville \& Nashville Ry. v. Citizens' \& People's Nat. Banls of Pensacola, 74 Fla. 385, 77 So. 104 (1917) (agent of payee who had authority to receive but not to cash checks obtained check); Brown v. People's Xat. Banl; 170 Mich. 416, 136 N.W. 5.13 (1912) (payee's delay in notification of drawee estonned recovery). And see notes 23,30 , 62 infra.

13. A random survey of 75 cases decided since 1930 shows the following results: Taker: won 6, lost 6; Collecting Bank: won 12, lost 5; Drawice Banl: : won 30, lost 31; Drawer: won 23, lost 30; True Ounter: won 7, lost 5. (The total is more than 75 since several cases involved more than one set of parties.)

14. Of the $\mathbf{7 5}$ cases, 21 involved forged checks, $\mathbf{5 0}$ involved forged endorsements, and four involved altered checks.

15. The extent to which negligence ductrines effect the allocation is indieated by the following breakdown of the 75 cases: 


\section{Allocation by Type of Forgery}

Traditionally, courts have attempted to place liability on different parties depending upon the type of forgery which gave rise to the loss. Thus different rules are applied to adjudicate the rights of parties under forged checks (i.c., where the drawer's signature is forged), forged endorsements, or materially altered checks.

Forged check. If a forged check is the cause of loss, application of standard doctrine will usually place liability on the drawee who pays out funds on the instrument. A typical situation occurs when a forger forges the name of a drawer of a check and uses the check to purchase goods at a store. The store endorses the check and deposits it at its bank for collection. The check is sent through banking channels and the bank on whom the check is drawn ultimately pays on the check and debits the account of the purported drawer. When the forgery is discovered, the law permits the purported drawer to force the drawee bank to recredit his account. ${ }^{16}$ But the drawee generally cannot recover from the collecting bank, ${ }^{17}$ and so the drawee is left with what is ustrally an

\begin{tabular}{lcccc} 
& If determined without & \multicolumn{2}{c}{ Considering } \\
& regard to & negligence & \multicolumn{2}{c}{ Negligence } \\
& Won & Lost & Won & Lost \\
Taker & 0 & 7 & 6 & 6 \\
Collecting Bank & 8 & 10 & 12 & 5 \\
Drawee Bank & 4 & 57 & 30 & 31 \\
Drawer & 55 & 4 & 23 & 30 \\
True Owner & 11 & 0 & 7 & 5
\end{tabular}

16. Federal Deposit Ins. Corp. v. Thompson, 54 Ga. App. 611, 188 S.E. 737 (1936); Couvilion v. Whitney Nat. Bank of New Orleans, 218 La. 1096, 51 So.2d 798 (1951); Barmley v. Merrimack Co-op Bank, 285 Mass. 37, 188 N.E. 378 (1933). See discussion note 6 supra, and additional cases cited notes 116, 124 infra. For negligence exceptions to the rule, see notes $39-43 a, 149,150$ infra.

17. This is usually considered an exception to the rule that money paid under mistake can be recovered. The leading cases are: Price v. Neal, 3 Burr. 1354, 97 Eng. Rep. 871 (K.B. 1762) ; Levy v. Bank of the United States, 1 Binn. 27 (Pa. 1802) ; Bank of United States v. Bank of Georgia, 10 Wheat. 333 (U.S. 1825). Contra: First Nat. Bank of Lisbon v. Wyndemere, 15 N.D. 299, 108 N.W. 546 (1906); cf. Union Nat. Bank v. Franklin Nat. Bank, 249 Pa. 375, 94 Atl. 1085 (1915). Diverse justifications are offered for the rule: (1) the drawee is conclusively presumed to know the signature of the drawer, First Nat. Bank of Quincy v. Ricker, 71 IIl. 439 (1874) ; Ellis \& Morton v. Ohio Life Ins. \& Trust Co., 4 Ohio St. 628 (1855); (2) the drawee is negligent in not detecting the forgery, Bank of Williamson v. McDowell County Bank, 66 W. Va. 545, 66 S.E. 761 (1909); (3) as between two innocent people who must suffer, he who has legal title must prevail, sec Ames, The Doctrine of Price v. Ncal, 4 HARv. L. Rev. 297, 299, (1891) ; (4) maintain confidence in negotiable paper, see Woodward, Tue LAw of QuAsi-ConTructs $\$ \$ 80-87$ (1913); (5) commercial convenience, see Justice Holmes in Dedham Nat. Bank v. Everett Nat. Bank, 177 Mass. 392, 59 N.E. 62 (1901). The rule has been incorporated in the NIL under expansion of $\S 62$, which provides that acceptor engages to pay instruments and admits the existence of the drawer and the genuineness of his signature. Cherokee Nat. Bank v. Union Trust Co., 33 Okla. 342, 125 Pac. 464 (1912) ; Fidelity \& Casual ty Co. v. Planenscheck, 200 Wis. 304, 227 N.W. 387 (1929); it may similarly be incor- 
empty right to recover from the forger. However, in the few situations where the drawee bank may discover the forgery before it pays on the check, it can return the check to the collecting bank without payment.18 The collecting bank will then recover from the store any funds it has advanced on the checl, 10 and thus the store that took the check from the forger will bear the risls of failure to apprehend the forger and recover the funds from him.

Forged Endorsement. When the loss is produced by a forged endorsement of an order instrument, the burden usually falls upon the party who talies the check from the forger. The forged endorsement cases arise, for example. when a forger steals or finds a genuine check which is an order instrument. He then forges the name of the payee, negotiates the check at a store, and the instrument follows the same course as the forged check previously discussed. The drawer of the check is generally protected, as.is the purported drawer in the case of a forged check, since he has a right to have his account recredited if the drawee bank has paid the check and debited his account. ${ }^{29}$ But

porated by inclusion in the law of merchants in NIL $\S 19 \mathrm{t}$. Sce Suuth Buston Trust Co. v. Levin, 249 Mass. 45,143 N.E. $\$ 16$ (1924).

Recovery is permitted, however, where no value has been paid for the check. First State Bank \& Trust Co. v. First Nat. Bank of Canton, 314 III. 269, 145 N.E. 382 (1924); American Surety Co. of New York v. Industrial Savings Bank, 242 Mich. 581,219 N.W. $6 S 9$ (1928), 27 MrCH. L. REv. 100 (1928); or if the recipient was not a holder in due course, Iron City Nat. Bank r. Peyton, 15 Tex. Civ. App. 184, 39 S.W. 223 (1897) ; or if presenter had or should have had knowledse of forgery. Banca Cumnercials Italianss Trust Co. v. Clarkson, 274 N.Y. 69, 8 N.E.2d 281 (1937). For negligence excegtions see cases cited notes 45,142 infra. For additional cases involing the main rule, sce notes 98 , 109, 117, 143 infra.

18. See cases cited note 4 supra. Acts which constitute irrerocable payment by the drawee bank vary. "Payment of cash for the check is final pasment. Fidelity \& Casualty Co. of New York v. Planenscheck, 200 Wis. 304, 309, 237 N.WY. 387, 359 (1929). Where a check is received through the collection system payment is full when pasting is completed. N.Y. NEg. INST. Law, Art. 19-A, \$ 351-b, as amended by N.Y. Law s of 1950, c. 153, $\$ 1$; but of. Cohen v. First Nat. Bank of Nogales, 22 Ariz. 392, 4 $111,1 \% \$$ Fae. 122, 124 (1921) (receipting for item or entry of provisional crcdit). Under the Asenucu:: Ba:inens Association Moder Deferred Postric Statute a drawee bank is allowed a full day aiter receipt of an item to determine whether or not to pay it, and may revole fayment until midnight of the day following receipt. Such statutes are in furce in must states.

19. See notes 5 and 9 supro.

20. Calaway v. Hamilton Nat. Bank, 195 F.2d 556 (D.C. Cir. 1952), 40 GEo. L.J. 626 (1952) ; National Bank of Detroit v. Fidelity \& Deposit Cu. of MId, 291 Mrich. 3t. 288 N.W. 325 (1939) ; Commonwealth v. Globe Indemnity Co., 323 Pa. 261, 185 Atl. 796 (1936) ; Shorti v. Industrial Trust Co., 75 R.I. 482, 67 A.2d 697 (1949); Guaranty State Bank \& Trust Co. v. Lively, 108 Tex. 393, 194 S.W. 937 (1917); and see nute 6 sugro. But a drawer is denied recovery if the forgery has not caused him loss bacause he received the proceeds of the forgery. National Surety Corp. v. City Eanls \& Trust $C_{0 .}$, 248 Wis. 32, 20 N.W.2d 559 (1945) ; Andrews v. Northwestern Nat. Bank, 167 MLinn. 196, 117 N.W. 621 (190S), aff'd on relearing, 122 N.W. 499 (1909). But cf. Life In Co. of Virginia v. Edisto Nat. Bank of Orangeburg, 166 S.L. 505, 165 S.E. 173 (1932). For negligence exceptions, see notes $48-59$ infra. 
contrary to the forged check rule, the drawee bank is entitled to reimbursement from the collecting bank for any funds paid on the check. ${ }^{21}$ The collecting bank can in turn fall back for recovery upon the store. ${ }^{22}$ Thus the store sustains the risk of loss contingent on recovery from the forger. The genuine payee, i.e., the true owner of the check, whose endorsement was forget is not deprived of his interest in the check, but has alternatives of recovering from the drawer, ${ }^{23}$ the drawee bank, ${ }^{24}$ the collecting bank, ${ }^{25}$ or the taker from the forger. ${ }^{26}$

21. Recovery has been permitted on theories of an implied warranty of title accompanying presentment for payment-United States v. National Exchange Bank, 45 Fcd. 163 (1891) ; money paid under mistake of fact-La Fayette \& Brothers v. Mlcrchants Bank of Ft. Smith, 73 Ark. 561, 84 S.W. 700 (1905) ; First Nat. Bank of Minnesota v. City Nat. Bank of Holyoke, 182 Mass. 130, 64 N.E. 24 (1902); Canal Bank v. Bank of Albany, 1 Hill. 287 (N.Y. 1841) ; or on basis of warranty as indorser under NIL $\$ \S 65$, 66-American Exchange Nat. Bank v. Yorkville Bank of N.Y., 122 Misc. 616, 204 N.Y. Supp. 621 (Sup. Ct. 1924) ; Kleinman v. Chase Nat. Bank, 124 Misc. 173, 207 N.Y. Supp. 191 (Sup. Ct. 1924). This latter ground is criticized since warranties are supposed to run only to holders not to the drawee. American Hominy Co. v. Millikin Nat. Bank, 273 Fed. 550 (S.D. Ill. 1920) ; First Nat. Bank v. United States Nat. Bank, 100 Orc. 264, 197 Pac. 547 (1921). The action may be defeated if the collecting bank is only a collecting agent under a restrictive endorsement and has turned proceeds over to the indorser. Cf. National City Bank v. Wescott, 118 N.Y. 468, 23 N.E. 900 (1890) ; Crocker Wool* worth Nat. Bank v. Nevada Bank, 139 Cal. 564, 73 Pac. 456 (1903). Similarly, where the bank has paid the true owner and thus has title. Talbot v. Bank of Rochester, 1 Hill. 295 (N.Y. 1841). In this latter case the instrument is discharged and the drawee cun credit drawer's account. For additional cases allowing recovery see note 8 supra.

22. See Aircraft Trading Co. v. Manufacturers' Trust Co., 297 N.Y. 285, 79 N.E. 2d 249 (1948); cases cited note 9 supra; discussion note 5 supra.

23. Hart v. Moore, 171 Miss. 838, 158 So. 490 (1935); Thomson v. Bank of British North America, 82 N.Y. 1 (1880) ; Siegel v. Kovensky, 93 Misc. 541, 157 N.Y. Supp. 340 (Sup. Ct. 1916); cases cited note 10 supra. The payee may lose his interest if the agent who obtained the check had authority to receive but not cash checks. Mills v, Hurley Hardware \& Furniture Co., 129 Ark. 350, 196 S.W. 121 (1917) ; Morrison v. Chapman, 155 App. Div. 509, 140 N.Y. Supp. 700 (1st Dep't 1913) ; Burnstein v. Sullivan, 134 App. Div. 623, 119 N.Y. Supp. 317 (2d Dep't 1911) ; Strickland Transport Co. v. First State Banls of Memphis, 147 Tex. 193, 214 S.W.2d 934 (1948), 11 Oн1о Sr. L.J. 112 (1950). Or he may be forced to sue some other party. McFadden v. Follrath, 114 Minn. 85, 130 N.W. 542 (1911) ; Burstein v. People's Trust Co., 143 App. Div. 165, 127 N.Y. Supp، 1092 (1911). See also note 12 supra; notes 30 and 62 infra.

24. Where a drawee formally accepts the check, the true owner may always recover. See e.g., Citizens \& Southern Nat. Bank v. Davis, 54 Ga. App. 836, 188 S.E. 589 (1936). Where there is no formal acceptance some jurisdictions permit recovery on theories of: (1) conversion-Louisville \& Nashville Ry. v. Citizens' \& People's Nat. Bank, 74 Fla. 385, 77 So. 104 (1917); Blacker \& Shepard Co. v. Granite Trust Co., 284 Mass. 9, 187 N.E. 53 (1933); Henderson v. Lincoln Rochester Trust Co., 303 N.Y. 27, 100 N.E.2d 117 (1951) (Contra: M. Feitel House Wrecking Co. v. Citizens Bank and Trust Co., 159 La. 752, 106 So. 292 (1925) ; Gordon Fireworks Co. v. Capital Nat. Bank, 236 Mich. 271, 210 N.W. 263 (1926); Strickland Transport Co. v. First State Bank of Memplis, 144 Tex. 193, 214 S.W.2d 934 (1948); Miller v. Northern Bank, 239 Wis. 12, 300 N.W. 758 
If the check is a bearer ${ }^{27}$ rather than an order instrument, a forged endorsement generally results in the drawer's sustaining the loss. A drawee banli which pays on such a check is able to debit the drawer's accuunt for funds paid out.2s And where the drawee bank has not paid, any good faith purchaser for value subsequent to the forgery will be able to compel the drawer to honor the instrument. ${ }^{29}$ The true owner, in the case of theft, will usually have an action against the drawer on any underlying debt for which the checl:

(1941)) ; (2) contract as money had and received-Independent Oil Men's Ass'n v. Fort Dearborn Nat. Bank, 311 IIl. 278, 142 N.E. 458 (1924); sie National Bank of the Republic v. Millard, 10 Wall. 152, 157-S (U.S. 1\$69) (Contra: First Nat. Banls v. Whitman, 94 U.S. 343 (1876) ; Lonier v. State Savings Bank, 149 Mich. 483, 112 N.W. 1119 (1907) ; Henderson v. Lincoin Rochester Trust Co., sufra; Baltimore \& Ohio Ry. v. First Nat. Bank, 102 Va. 753, 47 So. $\$ 37$ (1904)) : (3) constructive accertance-Chamberlain Metal Co. v. Bank of Pleasanton, 98 Kan. 611, 160 Pae. $113 S$ (1916) ; cf. Dawson v. National Bank of Greenfield, 196 N.C. 134, 144 S.E. $\$ 33$ (1923); United States Fidelity \& Guarantee Co. v. Jacobs, 287 S.W. 504 (Tex. Civ. App. 1926) (Contra: First Nat. Bank v. Whitman, 94 U.S. 343 (1876); Elyria Savings Banking Co. v. Waller Bin Co., 92 Ohio St. 406, 111 N.E. 147 (1915) ; Lone Star Trucling Co. v. City Nat. Banl: of Commerce, 240 S.W. 1000, (Tex. Civ. App. 1922)); (4) assignment of drawer's rights -Wormhoudt Lumber Co. v. Union Bank Trust Co., 231 Iowa 928, 2 N.W.2d 267 (1942). However, recovery may be denied if payee never received the checl- Jones v. Banl: of America Nat. Trust \& Savings Ass'n, 49 Cal. App.2d 115, 121 P.2d 94 (1942); but ef. Ubowich v. Northern Trust Co., 281 IIl. App. 109 (1936); or delayed without reason in pursuing his remedy-Annet v. Chase Nat. Bank, 196 App. Div. 632, 18S X.Y. Supp. 7 (1921). On the payee's right to sue drawce, sec Nots, 20 St. J.1H:s L. KEx. IUS (1951).

25. Recovery may be had in conversion: Good Roads Machinery Co. v. Broadway Bank, 267 S.W. 40 (Mo. App. 1924) ; Zidek v. Forbes National Bank, 159 Pa. Surar. 442, 48 A.2d 103 (1946) ; Evenson v. Waukesha Nat. Bank, 189 Wis. 170, 207 N.W. 415 (1926). In other jurisdictions recovery is in assumpsit: Mierchants' \& MIanufacturers" Ass'n v. First Nat. Bank, 40 Ariz. 531, 14 P.2d 717 (1932); Nationsl Union Bank of Xld. v. Miller Rubber Co., 148 MId. 449, 129 Atl. (US (1925); Kosacksr v. Cummcreial State Bank, 191 Minn 553, 254 N.W. $\$ 24$ (1934); Henderson v. Lincoln Rochester Trust Ca., 303 N.Y. 27, 100 N.E.2d 117 (1951). See also note 11 stipro.

26. The theories are the same as in suits against collecting banks; see note 25 styro. See Blacker \& Shephard Co. v. Granite Trust Co, 284 Mass. 9, 187 N.E. 53 (1933) (conversion); Universal Carloading \& Distributing Co. v. South Side Bank, 224 Mo. App. 876, 27 S.W.2d 768 (1930) (contract). Sce also note 11 stipro.

27. An instrument is payable to bearer when it is made cut "payable to bearer," or payable to a fictitious payee, or when the last indorsement is an indor:ement in blank. NIL § 9. Delivery negotiates a bearer instrument. NIL $\$ 316$.

28. Goodyear Tire \& Rubber Co. v. Wells Fargo Bank \& Trust Cu., 1 Cal. App.2d 694, 37 P.2d 483 (1934); Mueller \& Martin v. Liberty Ins. Banls, 187 Ky. 44, 218 S.W. 465 (1920); Snyder v. Corn Exchange Nat. Bank, $221 \mathrm{~Pa}$. 599, 70 Atl. 876 (190S). See also cases cited notes $51,52,115,118$ insfra.

29. Although these cases are most frequently litigated between the drawer and the drawee, the good faith purchaser has no less right to enforce payment than the drawee. See the leading cases of Tatlock v. Harris [1789] 3 T.R. 174 (K.L.); Minut v. Gibson [1789] 3 T.R. 481 (K.B.). Bearer paper can be enforced because nu endursement is necessary to transfer title. NIL $\$ 3 u$. 
was given as conditional payment. ${ }^{30}$ In the absence of an underlying debt the true owner sustains the loss.

Material Alteration. Doctrines applied when an instrument is materially altered usually place loss on the party who took the check from the forger. but the extent of loss varies depending upon the nature of the alteration. When the payee's signature is altered, the drawer is not liable on the check at all. ${ }^{31}$ When the drawee pays or certifies, in some jurisdictions the drawce sustains the loss, while in others all parties can fall back for recovery on prior parties who negotiated the check to them, ${ }^{32}$ i.e., the drawee can recover from the collecting bank and the latter can recover from the store who will then bear the loss for the full face amount of the instrument. However, if the amount of the check is altered, the drawer is usually liable for the original amount either to the drawee ${ }^{33}$ or to parties subsequent to the forgery who took the check in good faith and for value. ${ }^{34}$ As to the difference between the original and altered amounts, courts again split on whether the drawee sustains loss or whether parties may again fall back upon those who negotiated the check to them until ultimately the taker from the forger will sustain loss.

30. See cases cited notes 10,23 supra. But where the true owner recuuests that the check be mailed and the check is stolen fron the mails, he may be unable to recover from the drawer. See Graves v. American Exchange Bank, 17 N.Y. 205 (1858) ; SterFes, Casts on Conmerctal and Investanent Paper 378-9 (1939).

31. Union Tool Co. v. Farmers' \& Merchants' Nat. Bank, 192 Cal. 40, 218 Pac. 424 (1923). NIL § 124: "Where a negotiable instrument is materially altered without the assent of all parties liable thereon, it is avoided, except as against a party who has himself made, authorized or assented to the alteration and subsequent indorsers."

32. The majority view favors drawee's right to recover. Interstate Trust Co. v. U.S. National Bank, 67 Colo. 6, 185 Pac. 260 (1919); Central Nat. Bank v. F. W. Drosten Jewelry Co., 203 Mo. App. 646, 220 S.W. 511 (1920) ; Bank of Commerce v. Union Bank, 3 N.Y. 230 (1850) ; National Reserve Bank v. Corn Exchange Bank, 171 App. Div. 195, 157 N.Y. Supp. 316 (1st Dep't 1916); cases cited note 35 infra. Contra: CrockerWoolworth Nat. Bank v. Nevada Bank, 139 Cal. 564, 73 Pac. 456 (1903); National City Bank of Chicago v. National Bank of Republic, 300 Ill. 103, 132 N.E. 832 (1921), Comment, 31 Y ALE L.J. 522 (1922) ; Aetna Casualty \& Surety Co. v. Corpus Christi Nat. Bank, 186 S.W.2d 840 (Tex. Civ. App. 1944).

33. Glasscock v. First Nat. Bank of San Angelo, 114 Tex. 207, 266 S.W. 393 (1924); First State Bank of Lyford v. Parker, 27 S.W.2d 279 (Tex. Civ. App. 1930) ; 6 ZoLLINAN, BANKS \& BANRING 947-8 (1936).

34. People's Loan \& Finance Corp. v. Latimer, 183 Ga. 809, 189 S.E. 899 (1937); Smith, Kline \& French Co. v. Freeman, 93 N.J.L. 45, 106 Atl. 22 (Sup. Ct. 1919) ; Snyder v. McEwen, 148 Tenn. 423, 256 S.W. 434 (1923) ; Cooper v. Hampton, 123 S.W.2d 941 (Tex. Civ. App. 1939).

NIL $\$ 124$ provides: "But when an instrument has been materially altered and is in the hands of a holder in due course not a party to the alteration, he may enforce payment thereof according to its original tenor." Whether person is holder in due course may be a jury question. Miles City Bank v. Askin, 119 Mont. 581, 179 P.2d 750 (1947).

35. Compare McClendon v. Bank of Advance, 188 Mo. App. 417, 174 S.W. 203 (1915), New York Produce Exchange Bank v. Twelfth Ward Bank of City of New York, 144 App. Div. 896, 128 N.Y. Supp. 1136 (1st Dep't 1911), reversed on other grouths, 207 N.Y. 659, 100 N.E. 1131 (1912), with cases cited contra note 32 supra. 


\section{Allocation Modified by Negligcnce Doctrines}

Doctrines directed at placing liability on negligent parties frequently modify allocation of loss based on types of forgery. The development of these moditications has been a patchwork affair typical of the case by case development of common law. ${ }^{36}$ Some modifications, though originally based on negligence, have hardened into absolute rules of liability applied without regard to the particular conduct of the litigants. ${ }^{37}$ Elsewhere, standards of conduct, breach of which are deemed negligence, vary greatly from jurisdiction to jurisdiction and even from case to case within the same jurisdiction. ${ }^{3 \mathrm{~s}}$

While a drawee bank usually bears loss when it pays on a forged check. negligence doctrines may shift the loss to others. In some states statutes prescribe time limits, varying from one month to several years, within which the purported drawer who has his account debited for the forged check must discover and report the forgery to the drawee bank. ${ }^{30}$ Failure to do so will preclude the purported drawer from getting his account recredited; thus he, rather than the drawee, ${ }^{40}$ will sustain the loss. Jurisdictions similarly hold

36. The fictitious payee doctrine tvolves from Tatlock v. Harris, [1789] 3 T.R. 174 (K.B.) ; Minet v. Gibson, [17\$9] 3 T.R. HI (K.E.). The origins of the impostor rule are difficult to trace. The earliest case may be Elliot v. Smitherman, 19 N.C. 333 (1837). It was not applied in Tolman v. American Nat. Bank, 22 R.I. 462, 48 Atl. 480 (1901), but soon after was again used in the United States. Sherman v. Corn Exchange Banl:, 91 App. Div. 84, 86 N.Y. Supp. 341 (1st Dept 1904). The innoutor rule vas firmly ectablished by Boatsman v. Stockmen's Nat. Bank, 5u, Colo. 495, 138 Pac. 704 (1914). Conceptions of negligence of a depositor were advanced by Leather Mfanufacturers' Nat. Banls *. MLorgan, 117 U.S. 96 (18S6); Critten v. Chemical Bank, 171 N.Y. 219, 63 N.E. 969 (1902).

37. See notes $39,48-54,139140$ infra.

38. For variance in effect of leaving blank signed checls accessible to others, see note 151 infra. Variance in depositor's duty to discover forged endorsement is discussed note 56 infra, duty to supervise business is discussed note $153 \mathrm{infra}$, and duty to examine returned checks is considered note 154 infra. Varying anplication of the impostor rule is indicated at note $48 \mathrm{infra}$, and fictitious payee rule note $\mathbf{5 3} \mathbf{i n f f r a . ~ F o r ~ d i f f e r i n g ~ r e q u i r e - ~}$ ments for supervision of employees by payee, compare notes 62, 63 infra. For variance in negligence exception to forged check rule, see note $46 \mathrm{infro}$.

39. The depositor's duty to examine his returned checks in the early case of Critten v. Chemical Nat. Bank, 171 N.Y. 219, 63 N.E. 969 (1902) (where depositor eseoped liability) in some jurisdictions has become an absolute duty to report forgeries vithin a prescribed time or suffer loss. See, e.g., Greensboro Ice \& Fuel Co. v. Security Nat. Bank, 210 N.C. 244, 186 S.E. 362 (1936). Statutory time limits vary. One month limit: Ore Costr. Laws ANn. $\$ 40-1009$ (1940) ; 5 year limit: Ark. Stat. $\$ 37-209$ (1947); 10 year limit: see Selected Kentuchy Distillers v. Foloway, 124 W. Va. 72, 19 S.E.2d 94 (1942). See also Note, 139 A.L.R. 1280. Additional statutes are collected in Comment, 6 ARK. L. REv. 199, 208 n.71 (1952).

40. Atwell v. Mercantile Trust Co., 95 Cal. App. 33S, 272 Pac. 799 (1929); Wm. M. Barrett Inc. v. First Nat. Bank of Shreveport, 191 La. 945, 185 So. 741 (1939); Greensboro Ice \& Fuel Co. v. Security Nat. Bank, 210 N.C. 244, 186 S.E. 362 (1936) ; Provident Savings Bank \& Trust Co. v. Fifth-Third Union Trust Co., 43 Ohio App. 533, 183 N.E. 885 (1932). 
the purported drawer liable for failure to discover and report within a reasonable time by the use of doctrines of estoppel, ${ }^{41}$ ratification, ${ }^{42}$ breach of contractual duty, ${ }^{43}$ or account stated.43a But the negligence of the drawee may preclude it from charging a negligent drawer's account.44 In addition, many courts shift the loss on a forged check from the drawee to the collecting bank if the collecting bank has been negligent in accepting the check. ${ }^{45}$ However, the standards of negligence vary. ${ }^{46}$ Here the drawee can recover from

41. First Nat. Bank of Union Bridge v. Wolfe, 140 Md. 478, 117 At1. 898 (1922); National Production Co. v. Guardian Nat. Bank, 281 Mich. 230, 274 N.W. 774 (1937); Atlas Metal Works v. Republic Nat. Bank, 176 S.W.2d 350 (Tex. Civ. App. 1943); cf. Johnson v. First Nat. Bank of Beaver Falls, $367 \mathrm{~Pa}$. 459, 81 A.2d 95 (1951) (dictum). Contra: First Nat. Bank v. Allen, 100 Ala. 476, 14 So. 335 (1893); Housseman-Spitzley Corp. v. American State Bank, 205 Mich. 268, 171 N.W. 543 (1919).

42. Montgomery v. Crossthwait, 90 Ala. 553, 8 So. 498 (1890); De Feriet v. Bank of America, 23 La. Ann. 310 (1871) ; Coral Gables, Inc. v. Granara, 285 Mass. 565, 189 N.E. 604 (1934). Contra: First Nat. Bank v. Allen, 100 Ala. 476, 14 So. 335 (1893); Marsh v. State Bank \& Trust, 153 Tenn. 400, 284 S.W. 380 (1926). And see 1 Williston, Contracts 813 (2d ed. 1936); 1 Meecham, Agency $\$ 8360-3$ (2d ed. 1914); Note, 31 Yale L.J. 598 (1922).

43. First Nat. Bank v. Allen, 100 Ala. 476, 14 So. 335 (1893); National Dredging Co. v. President, etc., of Farmers' Bank of Delaware, 6 Pennewill 580, 69 Atl. 607 (Del. 1908). See also Neal v. First. Nat. Bank, 26 Ind. App. 503, 60 N.E. 164 (1901) ; Diamond v. Southwestern Nat. Bank, 103 Pa. Super. 589, 157 Atl. 626 (1931).

43a. See Janin v. London \& San Francisco Bank, 92 Cal. 14, 27 Pac. 1100 (1891); Pannonia Building \& Loan Ass'n v. West Side Trust Co., 93 N.J.L. 377, 108 Atl. 240 (Ct. Err. \& App. 1919). But cf. Worthen Bank \& Trust Co. v. Kelly-Nelson Construction Co., 245 S.W.2d 405 (Ark. 1952).

44. New York Produce Exchange Bank v. Houston, 169 Fed. 785 (2d Cir. 1909); Frankini v. Bank of America Nat. Trust \& Savings Ass'n, 31 Cal. App.2d 666, 88 P.2d 790 (1939) ; Gutfreund v. East River Nat. Bank, 251 N.Y. 58, 167 N.E. 171 (1929); First Nat. Bank v. Patty, 62 S.W.2d 629 (Tex. Civ. App. 1933). See also note 158 infra.

45. Hutcheson Hardware Co. v. Planters' State Bank, 26 Ga. App. 321, 105 S.E. 854 (1921); Bank of Pulaski v. Bloomfield State Bank, 226 N.W. 119, superceded by 210 Iowa 817, 232 N.W. 124 (1930) ; Ellis v. Ohio Life Ins. \& Trust Co., 4 Ohio St. 628 (1855) ; Farmers' Nat. Bank of Augusta v. Farmers' and Traders' Bank of Maysville, 159 Ky. 141, 166 S.W. 986 (1914) ; National Bank of North America v. Bangs, 106 Mass. 441 (1871) ; First Nat. Bank v. First Nat. Bank, 299 S.W. 856 (Tex. Civ. App. 1927). But if the drawee bank is also negligent it may not recover. San Francisco Nat. Bank v. American Nat. Bank of Los Angeles, 5 Cal. App. 408, 90 Pac. 558 (1907); Commercial \& Savings Bank v. City Nat. Bank of Franklin, 68 Ind. App. 417, 120 N.E. 670 (1918); First Nat. Bank of Portland v. United States Nat. Bank, 100 Ore. 264, 197 Pac. 547 (1921) ; Bank of Williamson v. McDowell County Bank, 66 W. Va. 545, 66 S.E. 761 (1909). For additional cases allowing recovery, see note 8 supra and note 142 infra. For cases contra, see note 143 infra.

46. Compare, e.g., the difficulty of satisfying the negligence standard established in Citizens' Bank of Fayette v. J. Blach \& Sons Inc., 228 Ala. 246, 153 So. 404 (1934) (identification of forger by papers including railroad passes, cards, deputation to make arrest and gold badge of railroad police; conduct bars recovery), with CommerceGuardian Bank v. Toledo Trust Co., 60 Ohio App. 337, 21 N.E.2d 173 (1938) (no identification in opening an account for forger; conduct does not bar recovery). 
the collecting bank. The latter, since it is usually the taker from the forger in these situations, is left with an empty right to recover against the forger. But the negligence of a party prior to the collecting bank will not enable the drawee bank to recover against the collecting bank even though such a recovery would ultimately shift loss to the negligent party. ${ }^{47}$

In cases involving forged endorsements, some negligence rules have been over-generalized into rules imposing absolute liability on the draver, thus relieving the party who takes from the forger. For example, when a drawer delivers a check to an impostor, courts hold that the signature by the impostor -even though a forgery-has the effect of a valid endorsement. ${ }^{45}$ Thus a drawee paying on the check can always debit the account of the drawer, and the drawer is left with the right of recovery against the forger. The frequently" inarticulate premise ${ }^{49}$ behind this "impostor rule" is the drawer's negligence

47. Germania Bank v. Boutell, 69 Minn. 189, 62 N.W. 327 (1895) (proteets talier who cashed $\$ 457$ check for a man of little means in order to settle $\$ 10$ account; purported drawer was in the same city) ; Fidelity \& Casualty Co. of N.Y. v. Planenscheck, 200 Wis. 304,227 N.W. 387 (1929) (protects taker who failed to notice that endorsement differed from payee's name); cf. First Nat. Bank of Portland v. United States Nat. Banls of Portland, 106 Ore. 264, 197 Pac. 547 (1921). But cf. Cairo Banking Co. v. West, 187 Ga. 666, 2 S.E.2d 91 (1939) (recovery by drawee permitted if any prior party negligent): Massachusetts Bonding \& Ins. Co. v. Pittsburg Pipe \& Supply Co., 135 S.W.2d 818 (Tex. Civ. App. 1940) (when all parties joined in suit drawee can sue prior parties).

48. Invacation of the impostor rule precludes the drawer from effectively asserting the forged endorsement. It is applied when an impersonator has deceived the drawer into issuing a check to him in the name of another person and then forges that name in order to transfer the check. Continental-American Bank r. United States, 161 F.2d 935, aff'd, 175 F.2d 271 (5th Cir. 1949); Schweitzer v. Bank of America Nat. Trust \& Savings Ass'n, 42 Cal. App.2d 536, 109 P.2d 441 (1941); Santz Mrria v. Industrial City Banls \& Banking Co., 326 Mass. 440, 95 N.E.2d 176 (1951) : Montgomery Garage Co. v. Manufacturers' Liability Insurance Co., 94 N.J.L. 152. 109 Atl. 296 (Sup. Ct. 1920); Halsey v. Bank of New York \& Trust Co., 270 N.Y. 134, 200 N.E. 671 (1936). Exceptions arise in which the rule may not be applied: (1) where contact is through the mails-Moore v. Moultrie Banking Co., $39 \mathrm{Ga}$ App. 687, 14 S S.E. 311 (1929); American Surety Co. v. Empire Trust Co., 262 N.Y. 181, 186 N.E. 436 (1933) (Confra: Bostsman v. Stoclsmen's National Bank, 56 Colo. 495, 13S Pac. 764 (1914); Uriola v. Twin Falls Banls \& Trust Co., 37 Idaho 332, $215 \mathrm{Pac} 1080$ (1923)) ; (2) where a confederate of the impostor mal:es the forgery-Russell v. Second Nat. Bank of Paterson, 136 N.J.L. 270, 55 A.2d 211 (1947) ; J. C. Hockett Co. v. Simmonds, \&4 Ohio App. 467, 87 N.E.2d 739 (1949); (3) when there is no intent to give the proceeds to the impersonator-International Aircraft Trading Co. v. Manufacturers' Trust Co., 297 N.Y. 285, 79 N.E.2d 249 (1948); Land Title Bank \& Trust Co. v. Cheltenham Nat. Bank, 362 Pa. 30, 66 A.2d 76S (1949) ; Storti v. Industrial Trust Co., 75 R.I. 482, 67 A.2d 697 (1949). For historial development of rule see note 36 supra.

49. The impostor rule has three justifications. The most frequently involsed rationale is that the drawer intended the impostor to have the procceds, and thus the forgery actually served to implement the drawer's intent. Ryan v. Bank of Italy National Trust \& Savings Association, $106 \mathrm{Cal}$. App. 690, 289 Pac. 863 (1930); Greenterg v. A\& D Motor Sales Inc., 341 Ill. App. 85, 19 N.E.2d 90 (1950); Robertson v. Culeman, 141 Miass. 231, 4 N.E. 619 (1886); Fiore v. Ladd, 22 Ore. 202, 29 Pac. 435 (1892). This 
in being duped by the impostor.50 Similarly, when a check is made out to a fictitious payee and is cashed by "forging" the payee's endorsement, the drawer is left in an identical situation. ${ }^{51}$ These cases arise, for example, when an employee authorized to write checks for his employer embezzles funds by making checks out to nonexistent parties and endorsing them to his own use. But aside from this situation, there is wide disagreement on the definition of a "fictitious payee" check. ${ }^{63}$ In any event the basis for imposing liability on

rationale is unsound because the drawer has actually two intents: he intends to pay the impostor, and he intends to pay the person being impersonated. The intent reasoning offers no justification for honoring the first intent over the second. See Cohen v. Lincoln Savings Bank, 275 N.Y. 399, 407-8, 10 N.E.2d 457, 461 (1937); Note, 23 IND. L.J. 484 (1948). The second basis is NIL $\S 61$, which states that the drawer "admits the existence of the payee and his then capacity to endorse; and engages that on due presentment the instrument will be accepted or paid, or both. . ." See Montgomery Garage Co. v. Manufacturers' Liability Ins. Co., 94 N.J.L. 152, 109 Atl. 296 (Sup. Ct. 1920). This rationale is inadequate since the named payee may actually exist and be able to endorse, and so forgery by an impostor of the real person should have no more effect than any other forgery under the NIL. See note 4 stipra. The third rationale is that the drawer is liable becatuse his negligence precludes asserting the forgery. See note 50 infra.

50. Cases discussing drawer's negligence include: United States v. National Exchange Bank, 45 Fed. 163 (1891) ; Central National Bank v. National Metropolitan Bank, 31 App. D.C. 391 (1908); Boatsman v. Stockmen's Nat. Bank, 56 Colo. 495, 138 Pac. 764 (1914); Cohen v. Lincoln Savings Bank, 275 N.Y. 399, 10 N.E.2d 457 (1937); Forbes v. Espy, 21 Ohio St. 474 (1871) ; Land-Title \& Trust Co. v. Northwestern Nat. Bank, $196 \mathrm{~Pa} .230,46$ Atl. 420 (1900). Note, [1950] WASH. U.L.Q. 130, 133. Unlike the situation in which an impostor receives cash, when an impostor has obtained a check the taker from the forger also has an opportunity to discover the fraud, and so the taker's negligence should also be considered before application of the negligence rule against the drawer. See Notes, 23 IND. L.J. 484 (1948), 7 WAshi. \& LEe L. Rev. 94 (1950) ; and result of decision in International Aircraft Trading Co. v. Manufacturers' Trust Co., 297 N.Y. 285, 79 N.E.2d 249 (1948), 23 ST. JoHN's L. Rev. 339 (1949).

51. Ellis Weaving Mills v. Citizens \& Southern National Bank of Spartanburg, 91 F. Supp. 943, aff'd, 184 F.2d 43 (4th Cir. 1951) ; Metropolitan Life Insurance Co. v. San Francisco Bank, 58 Cal. App.2d 528, 136 P.2d 853 (1943); Bourne v. Maryland Casualty Co., 185 S.C. 1, 192 S.E. 605 (1937); cases cited notes 52, 115, 118 infra. For historical development, see note 36 sipra.

52. Choctaw Grain Co. v. First State Bank of Jet, 175 Okla. 458, 53 P.2d 579 (1936); Litchfield Shuttle Co. v. Cumberland Valley National Bank, 134 Tenn. 379, 183 S.W. 1006 (1915) ; National Bank of Commerce v. Seattle National Bank, 109 Wash. 312, 187 Pac. 342 (1920); case cited note 118 infra. Contra: Ocean Accident \& Guaruttec Corp. v. Lincoln National Bank, 112 N.J.L. 550, 172 Atl. 45 (Sup. Ct. 1934).

53. If agent only supplies name of fictitious payee but does not sign check, check is not "fictitious payee check." Robertson Banking Co. v. Brasfield, 202 Ala. 167, 79 So. 651 (1918) ; Edgington v. Security-First National Bank of Los Angeles, 78 Cal. App.2d 849, 179 P.2d 640 (1947); Johnston v. Exchange National Bank of Tampa, 152 Fla. 228, 9 So.2d 810 (1942); American Sash \& Door Co. v. Commerce Trust Co., 332 Mo. 98, 56 S.W.2d 1034 (1932); cases cited note 116 infra. Contra: Citizens Loan and Security Co. v. Trust Co. of Georgia, 79 Ga. App. 184, 53 S.E.2d 179 (1949); Houghton-Mifflin Co. v. Continental Illinois National Bank and Trust Co., 293 Ill. App. 423 (1938); Swift 
the employer is his presumed failure to exercise adequate supervision over his employees. ${ }^{54}$

In forged endorsement cases there are also flexible negligence doctrines that shift loss to the drawer and away from the party who talies from the forger. As in the case of a forged check, failure of the drawer to discover and report a forgery to the drawee may estop him from having his account recredited. 55 However, his "duty to discover and report" is less than the duty" in forged check cases. ${ }^{50}$ Additionally, the drawer's carelessness in delivering;

and Co. v. Bankers Trust Co., 280 N.Y. 135, 19 N.E.2d 992 (1939). And see cases cited note 115 infra. Where one of two authorized signers knew fictitious nature of payce, same result. Security Savings Bank v. First National Bank, 106 F.2d 542 (Gth Cir. 1939); Board of Education v. National Union Bank of Dover, 121 N.J.L. 177, 1 A.2. $3831 \mathrm{Ct}$. Err. \& App. 1938). Contra: Goodyear Tire \& Rubber Co. v. Wells Fargo Banls \& Union Trust Co., 1 Cal. App.2d 694, 37 P.2d 483 (1934); Noel v. Security Banl: of Chicage, 163 I11. App. 82 (1911) ; Globe Indemnity Co. v. First National Banls in St. Louis, 133 S.W.2d 1066 (Mo. App. 1939); National Surety Corp. v. Federal Recerve Banli, 161 Misc. 304, 292 N.Y. Supp. 607 (Sup. Ct. 1936), aff'd, 250 Arp. Div. 754, 296 X.Y. Supp. 240 (1st Dep't 1937). See Note, 26 NEB. L. Rev. 436 (1947).

54. See American Hominy Co. v. Millikin National Banl, 273 Fed. 550 (S.D. III. 1920) ; Defiance Lùmber Co. v. Bank of California, 180 Wash. 533, 41 P.2d 135 (1935). See Comment, 1S U. of CHI. L. Rev. 281 (1921).

The fictitious payee rule originated to place the loss on the person who drew an instrument on his own funds; thus it was always the conduct of the owner of funds which caused his loss. Tatiock v. Harris, [1759] 3 T.R. 174 (K.li.). When it was early suggested in the modern check context as a device to place the loss on an owner of funds whose dishonest employee supplied fictitious names to his employer, it was denied. Shipman v. Bank of State of New York, 126 N.Y. 318, 27 N.E. 371 (1891). But when the employer had given his employee authority to sign the checks, courts applied the rule even though the signer was not owner of the funds. Suyder v. Corn Exchange Nat. Eant: $221 \mathrm{~Pa}$ 599, 70 Atl. 876 (1908). In its modern application the rule reaches even the Shipmos! facts regardless of the absence of negligence of the owner of funds. Swit $\$$. Co. v. Chemieal Bank \& Trust Co., 280 N.Y. 135, 19 N.E. 992 (1939).

55. United States v. National City Bank of X.Y., 23 F. Supr. IH IS.D.X.X. 1939, (laches); Royal Indemnity Co. v. Federal Resurve Bank, 3\$ F. Sulfu t.21 (S.D. Oni, 1939), aff'd, 119 F.2d 77S (6th Cir. 1941) (two year delay after discovery tars without showing of detriment by defendant) ; Union Trust Co. v. Soble, 6f A.2d 744 (MId. 1949) (estoppel even if no detriment to defendant although here there was some detriment); Scott v. First Nat. Bank, $3+3$ MIo. 77, 119 S.W.2d 929 (1938) (aiter lnowledge that there was shortage of $\$ 10,000$ employer estopped from recovering on subsequent forged endorsements) ; Connors v. Old Forge Discount \& Deposit Banls, 245 P3. 97, 91 Atl. 210 (1914) (43 day delay after discovering forgery bars recovery even if no prejudice to defendant).

56. No duty to examine endorsement to discover forgery: Iirst Nat. Banls wi citasit v. American Surety Co., 71 Ga App. 112, 30 S.E.2d 402 (1944); Wormhoudt Lumber Co. v. Union Bank \& Trust Co., 231 Iowa 928, 2 N.W.2d 260 (1942); Jordan Marsh Co. v. National Shawmut Bank, 210 Mfass. 397, 87 N.E. 740 (1909); National Surety Co. v. President and Directors of Mranhattan Co., 252 N.Y. 247, 169 N.E. 372 (1929). No duty even when the payees' signature is in drawer's pussession: LiLarty Mutual In:. Co. v. First Nat. Bank in Dallas, _ Tex. - 245 S.W.2d 237 (1951); Bcard oi Education v. National Union Bank of Dover, 121 N.J.L. 177, 1 A.2d $3 \times 3$ (Ct. Err. \& App. 
a check, as by improper mailing, will lead some courts to place the loss upon him rather than upon the taker from the forger. ${ }^{.7}$ And negligence in supervision of employees and agents, aside from the fictitious payee situations, may also result in the drawer's liability. ${ }^{58}$ Some courts refuse to hold the drawer liable for negligent supervision, however, on the theory that the forger's illegal action arising after the negligence is the real cause of loss. ${ }^{\text {b9 }}$ In each of the foregoing situations where negligence is considered an operative fact, the drawer is unable to compel recrediting of his account and thus generally remains with the right of action against the forger.

Losses from forged endorsements may also shift to the true owner where he is negligent. When the negligence of the true owner is considered operative, it will bar all or part of his recovery from any party except the forger. Thus a true owner who discovers but fails to give notice of a forged endorsement will bear the entire loss in some jurisdictions, ${ }^{60}$ while in others he will be held liable only for the portion of loss resulting from his failure to notify. ${ }^{11}$

1938) (some forged endorsements were of depositor's own signature). Contra: Royal Indemnity Co. v. Federal Reserve Bank, 38 F. Supp. 621 (S.D. Ohio 1939), aff'd, 11 ) F.2d 778 (6th Cir. 1941). Statutes requiring depositor to report forgery to bank within given time generally are not applicable to forged endorsements. Atwell v. Mercantile Trust Co., 95 Cal. App. 338 (1928) ; McCornack v. Central State Bank, 203 Iowa 883, 211 N.W. 542 (1926) ; Board of Education v. National Union Bank of Dover, supra; Kleinman v. Chase Nat. Bank, 124 Misc. 173, 207 N.Y. Supp. 191 (Sup. Ct. 1924).

57. Keck v. Browne, 314 Ky. 151, 234 S.W.2d 183 (1950), 39 Kx. L.J. 476 (1951); Slattery \& Co. v. National City Bank of New York, 114 Misc. 48, 186 N.Y. Supp. 679 (Sup. Ct. 1920); Weisberger Co. v. Barberton Savings Bank, 84 Ohio St. 21, 95 N.E. 379 (1911). Majority view is contra: Cochran v. Atchison, 27 Kan. 728 (1882); Beattic v. National Bank of Illinois, 174 Ill. 571, 51 N.E. 602 (1898); Thomas v. First Nat. Bank of Gulfport, 101 Miss. 500, 58 So. 478 (1912) ; Vecchia v. Fidelity Union Trust Co., 114 N.J.L. 470, 177 Atl. 429 (Sup. Ct. 1935); Market Street Title \& Trust Co. v. Chelten Trust Co., $296 \mathrm{~Pa}$. 230, 145 Atl. 848 (1929).

58. Negligent conduct barring recovery includes the rehiring of a known embezzler, De Feriet v. Bank of America, $23 \mathrm{La}$. Ann. 310 (1871); the failure to discover why costs have suddenly increased, Detroit Piston Ring Co. v. Wayne County \& Home Savings Bank, 252 Mich. 163, 233 N.W. 185 (1930); and the permitting of an agent to endorse checks in customers' names, Bartlett v. First Nat. Bank of Chicago, 247 111. 490, 93 N.E. 337 (1910).

59. Fitzgibbons Boiler Co. v. National City Bank, 287 N.Y. 326, 39 N.E.2d 897 (1942) ; Provident Savings Bank \& Trust Co. v. Western \& Southern Life Insurance Co., 41 Ohio App. 261, 179 N.E. 815 (1931) ; Land-Title Bank \& Trust Co. v. Cheltenham Nat. Bank, 362 Pa. 30, 66 A.2d 768 (1949); Glasscock v. First Nat. Bank of San Angelo, 114 Tex. 207, 266 S.W. 393 (1924). Contra: Connecticut Savings Bank of N.H. v. First Nat. Bank and Trust Co., 138 Conn. 298, 84 A.2d 267 (1951). '

60. Brown v. People's National Bank, 170 Mich. 416, 136 N.W. 506 (1912); Annet v. Chase National Bank, 196 App. Div. 632, 188 N.Y. Supp. 7 (1st Dep't 1921); Marks v. Anchor Savings Bank, 252 Pa. 304, 97 Atl. 399 (1916); State v. First National Bank of Montrose, $203 \mathrm{~Pa} .69,52$ Atl. 13 (1902). Contra: Independent Oil Men's Ass'n v. Fort Dearborn National Bank, 311 IIl. 278, 142 N.E. 458 (1924).

61. Clearfield Trust Co. v. United States, 318 U.S. 363 (1943) ; Lindenthal v. Northwest State Bank, 221 Ill. App. 145 (1921); Blum v. Whipple, 194 Mass. 253, 80 N.E. 501 (1907). 
Additionally, the true owner may sustain the entire loss when inadequate supervision of his employees and agents contributed to the successiul forgery.2 But as in the case of a drawer's negligent supervision, courts vary widely in determining the surveillance required. ${ }^{03}$

In altered check cases, loss created by the alteration may fall on a negligent drawer rather than the party taking the check from the forger. Thus, if a drawer makes alteration easy by writing his check in pencil ${ }^{\text {os }}$ or with large spaces on the line on which the amount is indicated, ${ }^{65}$ some courts will holl him liable for the changed amount.

\section{Allocation Modified by Availability of Defenses}

A generally unintended but nevertheless significant factor influencing allocation of forgery losses is the unavailability of certain defenses to some defendants. Generally, substantive issues such as the rule for a particular type of forgery or the negligence of parties may be pleaded as a defense when recovery is sought on the check. The effects of these issues on allocation of loss have already been discussed in prior sections. However, in certain situations the law will not permit some of these issues to be raised.

Waiver of a defense by one party may prevent the assertion of the defense by another party. For example, a drawer's failure to give timely notice of a forged or altered instrument to the drawee bank would bar his recovery from

62. General Cigar Co. v. First Nat. Bank of Portland, 290 Fed. 143 (9th Cir. 1923); Strickland Transportation Co. v. First State Bank of Memphis, 214 S.W. $2 d 934$ (Te: 1948). Sometimes payee's recovery is denied on rationale that his agent had apparent authority to endorse. Kansas City II. \& B.R. Co. v. Ivy Leaf Coal Co., 97 Ala 705, 12 So. 395 (1892) ; Indemnity Mutual Marine Assurance Co. v. Powell, 216 MIo. App. 673, 271 S.W. 538 (1925) ; Morris v. Hofferberth, 81 App. Div. 512, 81 N.Y. Supp. 403 (1st Dep't 1903), affd, 73 N.E. 1127 (1903). See also Fidelity \& Casualty Co. of N.Y. v. First Nat. Bank \& Trust Co. of Fargo, 71 N.D. 413, 1 N.W.2d 401 (1941) ; cases cited note 12 stspra.

63. Compare cases in note 62 supra, arith the following: Hacker \& Shephard Co. v. Granite Trust Co., 284 Mass. 9, 187 N.E. 53 (1933) (payee company's vice-president made unauthorized endorsement) ; Hart v. Moore, 171 Miss. $\$ 3 S, 15 S$ So. 490 (1935) (payee recovers despite dishonest agent); Universal Carloading \& Distributing Co. v South Side Bank, 224 Mo. App. 876, 27 S.W.2d 768 (1930) (payee recovers from one who tools from dishonest employee) ; Burstein v. People's Trust Co., 143 App. Div. 165, 127 X.Y. Sugp. 1092 (1st Dep't 1911) (payee recovers from one who tool from dishonest agent degpite inability to recover from drawer).

64. Harvey v. Smith, 55 Ill. 224 (1870); Foutch v. Alexandria Banl: \& Trust Co, 177 Tenn. 348, 149 S.W.2d 76 (1941). Contra: Walsh v. Hunt, 120 Cal. 46, 52 Pac. 115 (1S98); Commercial Bank v. Arden \& Fraley, 177 Ky. 520, 197 S.W. 951 (1917); Lanier v. Clarke, 63 Tex. Civ. App. 266, 133 S.W. 1093 (1910). Problem diseussed in Notes, 23 Col. L. Rev. 184 (1923), 32 Yale L. J. 413 (1923).

65. Young v. Grote, [1827] 4 Bing. 253; Yocum v. Smith, 63 Ill. 331 (1871); Haclictt v. First Nat. Bank, 114 Ky. 193, 70 S.W. 664 (1912); Garrard v. Haddan, 67 Pa. 82 
the bank, and place the loss on the drawer. ${ }^{66}$ But if the drawee bank chooses to waive the defense and recredit the drawer's account, in a subsequent stit by the drawee bank against a collecting bank, the drawer's delay in notification would be no defense for the collecting bank. ${ }^{67}$ Nor could the collecting bank, having refunded money on the check, recover from the drawer. ${ }^{\text {s }}$ In another situation, where a collecting bank can resist suit by a drawee bank because the latter paid a forged instrument, ${ }^{60}$ if the collecting bank chooses to refund payment to the drawee, it may successfully sue the party who presented the check for collection. ${ }^{70}$ The presenter would not be able to raise the defense that the drawee bank had paid on the check, nor could the presenter later sue the drawee.

Even when the party against whom a defense is asserted is before the court, particular defendants may be barred from raising the defense. This occurs, for example, where a drawer who failed to give timely notice to the drawee of a forged endorsement or alteration sues a collecting bank. ${ }^{71}$

(1870) ; National Bank v. Nolting, 94 Va. 263, 26 S.E. 826 (1897). Contra: The Knoxville Nat. Bank v. Clark, 51 Iowa 264 (1879); Cape Ann Nat. Bank v. Burns, 129 Mass. 596 (1880); National Exchange Bank v. Lester, 194 N.Y. 461, 87 N.E. 779 (1909); Searles v. Seipp, 6 S.D. 472, 61 N.W. 804 (1895). See Note, 31 Harv. L. Rev. 779 (1918).

66. See notes 39-43a supra.

67. Fallick v. Amalgamated Bank of N.Y., 232 App. Div. 127, 249 N.Y. Supp. 238 (1st Dep't 1931) ; National Surety Corp. v. Federal Reserve Bank, 188 Misc. 207, 70 N.Y.S.2d 636 (Sup. Ct. 1946) ; American Exchange Nat. Bank v. Yorkville Bank, 122 Misc. 616, 204 N.Y. Supp. 621 (Sup. Ct. 1924). But cf. First State Bank \& Trust Co. v. First Nat. Bank of Canton, 314 IIl. 269, 145 N.E. 382 (1924); Merchants' Nat. Bank v. Federal State Bank, 206 Mich. 8, 172 N.W. 390 (1919). An act to allow the collecting bank to avail itself of the protection was passed by the New York Legislature in 1949, but the Governor vetoed it.

68. Manufacturers' Bank of Cohoes v. Prudential Ins. Co. of America, 102 Misc. 339, 168 N.Y. Supp. 913 (Sup. Ct. 1918).

69. See discussion at note 17 supra.

70. The collecting bank's right of action is on the warranty given by the endorser. See notes 5, 9 supra. This warranty does not run to the drawce; so the latter may not be able to sue the prior party. See note 47 supra.

71. The right of drawer to sue collecting bank is based on theories of (1) conversion: Home Indemnity Co. v. State Bank of Fort Dodge, 233 Iowa 103, 8 N.W.2d 757 (1943); Decker v. Mathews, 12 N.Y. 313 (1855) ; or (2) subrogation to drawee's claim: Washington Mechanics' Savings Bank v. District Title Ins. Co., 65 F.2d 827 (D.C. Cir. 1933); Gustin-Bacon Mfg. Co. v. First Nat. Bank of Englewood, 306 Ill. 179, 137 N.E. 793 (1922), 36 Harv. L. Rev. 879 (1923) ; Life Ins. Co. of Virginia v. Edisto Nat. Bank of Orangeburg, 166 S.C. 505, 165 S.E. 178 (1932) (to avoid circuity of action); National Surety Co. v. City Bank \& Trust Co., 248 Wis. 32, 20 N.W.2d 559 (1945) (recovery denied because drawer had received proceeds of check); or (3) money had and reccived: Figuers v. Fly, 137 Tenn. 358, 193 S.W. 117 (1917); United States Fidelity \& Guaranty Co. v. First Nat. Bank of E1 Paso, 93 S.W.2d 562 (Tex. Civ. App. 1936). Suit is not permitted by some states on the theory that the collecting bank did not receive drawer's funds since drawer has right to have his account with drawee bank recredited. California Mill Supply Corp. v. Bank of America, 36 Cal.2d 334, 223 P.2d 849 (1950); Lavanier 
Though his delay would prevent recovery against the drawee bank, the defense can not be raised by the collecting bank. ${ }^{72}$ Also where a taker from the forger was negligent in taking a forged check, and then processed it through a collecting bank, the drawee cannot recover from the negligent taler even if the latter is before the court. ${ }^{33}$

\section{Evaluation of Current Methods of Allocatrong Loss}

\section{Standards for Evaluation: Objectives in Loss Allocation}

The overall goal in allocation of forgery losses is to serve the commercial community by utilizing doctrines which encourage and facilitate good business practices and which allocate losses as equitably as possible. To achieve these results, four specific objectives have been suggested by courts and commentators: promotion of transferability. ${ }^{74}$ placing loss on the best risl: bearer, ${ }^{75}$

v. Cosmopolitan Bank \& Trust Co., 36 Ohio App. 285, 173 N.E. 216 (1929) ; First Nat. Bank of Bloomingdale v. North Jersey Trust Co., 18 N.J. Misc. 449, 14 A.2d 765 (Sup Ct. 1940) ; Trojan Pub. Corp. v. Manufacturers' Trust Co., 117 N.Y.L.J. 1914 (Sup. Ct. 1947), aff'd mem., 273 App. Div. S43, 76 N.Y.S.2d S45, aff'd mem., 298 N.Y. 771, 83 N.E.2d 465 (1948). See Corker, Risk of Loss from Forged Indorsements, 4 STAx. L. REv. 24 (1951): cases cited note 178 infra.

72. National Surety Co. v. President and Directors of MIanhattan Co.n 252 N.Y. 247, 169 N.E. 372 (1929) ; Fallick v. Amalgamated Bank of N.Y., 232 App. Div. 127, 249 N.Y. Supp. 238 (1st Dep't 1931); American Exchange Nat. Bank v. Yorlville Banl:, 122 Misc. 616, 204 N.Y. Supp. 621 (Sup. Ct.), aff'd, 210 App. Div. \$\$5, 206 N.Y. Supp. 879 (1st Dep't 1924). See Note, Liability of Collecting Ranls to Drater for Paymant on Forged Indorsement, 49 IIrCH. L. Rev. 1216 (1951).

73. See cases cited note 47 supra.

74. Courts have explicitly considered the promotion of transferability: United States v. First Nat. Bank, 131 F.2d 985 (10th Cir. 1442). cort. den.. 318 U.S. 774 (1943) (subjugation of Federal Government checks to impostor rule to promote their transferability). In the leading case on the forged endorsement rule Chief Justice Kenyon spealing for the minority in opposition to the rule pointed out that "it would throw too great a burden on persons taking bills of exchange to require proof of an indorsee that the persen from whom he received the bill was the real payee:" Mfead v. Yuung, [1790] 4 T.R. 28,30 (K.B.). Recently Justice Garwood pointed out: "It is still more likely that such immunity on the part of drawee banks will result in a loss of public contidence in the present highly useful system of 'pay by check' which banks have done so much to promote." Stricliland Transp. Co. v. First State Bank of Memphis, 147 Tex. 143, 217, 214 S.W.2d 934, 948 (1948) (dissent). See discussions in Notes, 27 INv. L.J. $511,5(13$ (1952), 81 U. of FA. L. Fev. 617 (1933), [1950] WASH. U.L.Q. 130, 133 (1950).

75. For suggestions of this policy see Iidelity \& Casualty Co. v. Planencehecl, 200 Wis.

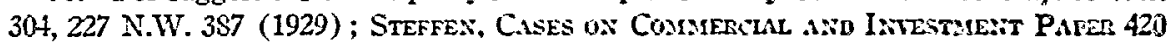
(1939) ; Beutel, The Proposed Iniform (") Commerial Code Should Not be Adosted, 61 YALE L.J. 334, 35S-9, 361 (1952); Corker. Kish of Loss from Forged Indorscmcits, 4 Stax. L. Ret. 24, 30-1 (1951) ; Kessler, Furged Endersoments, 47 Y.uLs. L.J. \$63, \$96-7 (1938) ; Note, Liability of Bank for Frands of Depositor's Employec, 14 U. of CHI. L. REr. 705 (1947); Comment, Share Certificate Negotialility, 7 U. of CHI. L. Rev. 497 (1940). 
placing loss on the negligent party, ${ }^{76}$ and uniformity of result in application of the preceding standards.77

Promoting Transferability. If checks are to serve as popular documents for both payment and circulation, parties must be able to transfer them with a minimum of formal requirements. ${ }^{78}$ For example, the check becomes a more efficient business device as formal requirements attaching to transfer decrease, for time and effort are valuable assets in the commercial world. And since most checks circulate to some extent-at least through the banking system in the collection process ${ }^{\mathbf{7 9}}$-simplicity of transfer as a catalyst in commercial transactions becomes even more significant.

The extent to which checks will be useful to the community also depends upon the protection afforded to parties who take them for value in good faith. Inevitably, parties will be more willing to accept checks if they are reasonably certain that they will not sustain either the loss of the value of the instrument or expenses of litigation. ${ }^{80}$ Similarly, from the standpoint of circulation, protection of banks dealing with checks in the collection process will expedite that process by diminishing the number of times parties must fall back on prior negotiators when they cannot obtain payment. ${ }^{81}$ In terms of

76. An early expression of the policy was made by Lord Mansfield: "Each party is innocent [of the forgery crime] ; the question is, on whom the loss must fall?-it should be on him who is most in fault." Smith v. Shepperd, Hil. Term 16 Geo. III (1776). The search for the negligent party exists in many types of forgery situations. See c.g., notes 39-45, 49-58, 60, 63 supra. For discussion, see Kessler, supra note 75, at 897 : Comment, Fictitious Payee \& the U.C.C., 18 U. of CEI. L. Rev. 281, 288 (1951).

77. Desire for uniformity suggested Clearfield Trust Co. v. United States, 318 U.S. 363 (1943). See STEFFEN, op. cit. supra note 75, at App. viii-ix; Sherman, Dratece's Liability for Retention of a Check Versis the Pennsylvania NIL, 12 U. OF PITT. L. Rev. 522 (1951).

78. Banks rely on the ready transferability of checks to promote use of checking accounts. See, e.g., The Woman AND Her Bank (1951) distributed by the Union \& New Haven Trust $\mathrm{Co}$. urging use of checks because of "the convenience of being able to pay bills by check and of exchanging checks for cash wherever you are known." See also note 74 stipra.

79. Over five billion checks circulate annually in the United States. Wood, Bank Forgery Hazard, 32 Protective Bulletin No. 8 (1940). As of $1941 \$ 537,398,000,000$ annually was debited by banks on checks written by depositors. BRITTON, BILLS AND NoTEs 1-2 (1943).

80. This has been one of the justifications for the forged instrument rule. Woodwrwu, The Law of Quasi-Contracts $\$ \S 80-7$ (1933). Justice Poffenbarger urges: "I adhere to the rule declared in Price v. Neal. . . Lack of this rule would not only impede commercial transactions, but also introduce unnecessary and grave elements of uncertainty and danger, and render the whole commercial system unstable and treacherous as well as too slow to meet ordinary business demands." Bank of Williamson v. McDowell County Bank, 66 W. Va. 545, 553-4, 66 S.E. 761,765 (1909). The impostor rule taking the loss from transferees has also been justified to reduce loss of parties taking checks. ContinentalAmerican Bank v. United States, 161 F.2d 935 (5th Cir. 1947), aff'd on rellearing, 175 F.2d 271 (5th Cir..1949).

81. Transferability is favored by closing transactions. National Bank of Sanford v. Marshburn, 229 N.C. 104, 27 S.E.2d 793 (1948). Justice Holmes regarded the forged 
allocating loss, protecting the purchaser shifts the risk of loss to the true owner, the drawee bank, or the drawer. This may create double liability for the drawer: liability on the instrument to subsequent parties, and liability to the true owner on the underlying obligation for which the draver gave the check as conditional payment. ${ }^{82}$ When the true owner cannot recoup from the drawer, the ultimate risk of loss would fall on him. ${ }^{83}$ However, while it is true that protection of the taker makes parties more willing to accept checlss, when it entails a drawer's double liability, it may hinder transferability by discouraging drawers from making payments by checl.os This suggests that the promotion of transferability may also entail some limitation of the drawer's liability.

Placing loss on the best risk bcarcr. In recent years the widespread use of insurance has led to suggestions that courts seek out the institutions which can most readily insure against forgery losses and pass the cost of insurance on to those who share in the protection. ${ }^{\text {ss }}$ Providing security against loss and equitably distributing the social cost of the check both justify such risk distribution. When loss is placed on a party who has insured against it, no one loses the total amount of the instrument. Nor do parties run the risk of sustaining loss because of the insolvency of prior parties associated with the check. It has been suggested, however, that centering loss on insured parties will lead to higher rates for insurance which the insured will be forced to pay. ${ }^{80}$

instrument rule as based on the desire to close commercial trancactions. Dedham Nat. Banl: v. Everett Nat. Bank, 177 Mass. 392, 59 N.E. 62 (1901). Transferability has also bzen offered as justification for refusing recovery by a drawee bank from prior parties on payment creating an overdraft. Spokane \& Eastern Trust Co. v. Huff, 63 Wash. 225, 115 Pac. 80 (1911).

82. This might arise, for example, where negligent mailing makes the drawer liable on the instrument. See note 57 supra. His debt to the intended payee remains undischarged. See notes 10,23 supra. Where the drawer was not negligent he may be protected against double liability. McFadden v. Follrath, $11+$ Minn. 85, 130 N.W. 542 (1911) (payee's action must be against drawee not drawer); see note 30 supra.

\$3. See cases cited notes $12,23,62$ stpra.

84. The civil law jurisdictions adhering to the Geneva Code have ensured ready transferability by creating a system in which a forger can convey good title. The good faith purchaser of an instrument with a forged endorsement obtains an enforcable title against all parties liable on the instrument. Genevs Cone Arts. 7, 16, 40,69. See United States v. Guaranty Trust Co., 293 U.S. 340 (1934) (forgery in Yugoslavia on check issued in the United States passed valid title to subsequent holder under Yugoslav law). The suggestion that this continental solution of allowing a forgery to pass good title restricts issuance of checks is made by Chalmers in LEAGUE OF NATIO:IS, Urimicition: of Laws Recating to Bills of Exchange and Prumissuse Notes 103 (1923); Kessler. supra note 75, at 895 . There is no question that checls are much less uscd on the continent than in the United States, but the causal relationship has never been established. Ib:d.

85. See note 75 supra.

86. George W. Adlam, Manager, Insurance Department of the Todd Company reports, "All of these bonds [Banker's Blanket Bond] are written on what we term an experience rating. That is, at the end of each premium year, the experiente of the bank is analyzed, 
But in so far as the risk bearer can distribute the costs among check users, the expense will in fact be shared ratably by many who benefit from the insurance.

In terms of loss allocation, choice of the best risk bearer would shift loss to the drawee bank. ${ }^{87}$ The bank, in charging rates for commercial accounts, can pass on the cost of insurance to those drawing checks in proportion to the number of checks they use. ${ }^{88}$ While subsequent takers may share in the protection afforded without sharing in the cost, (except, of course, as they themselves draw checks), drawers and drawees gain not only the direct protection from the possibility of loss but also benefit indirectly from the assurance afforded to transferees, since people will be more willing to take checks from drawers if the risk of loss is diminished.

Other parties are not able to gather and distribute the risk as effectively as the drawee bank. If drawers or all transferees sought to protect themselves independently, the multiplicity of policies would increase the total administrative costs of the insurance. ${ }^{80}$ For, in addition to the drawee, only a

and if they have had a very bad experience, and the insurance company has been forced to pay considerable losses, the premium is upped. If their experience has been good, the premium goes down. I haven't available the exact figures, because it is practically tailormade for each individual bank." Communication from George W. Adlam to YALE LAW JouRNAL, dated Mar. 27, 1952, on file in Yale Law Library.

87. Banks insure against forgery losses by taking out the Banker's Blanket Bond. The history of its development is reported in Boardman, Proper Construction of the SoCalled "Bankers" Amendment" to Section 9(3) of the Negotiable Instrument Act, 17 Iss. Coun. J. 166 (1950). Forgery losses covered by the Banker's Blanket Bond include: any loss through forgery or alteration of checks including checks made payable to a fictitious payee and endorsed in the name of the fictitious payee, or checks procured in a face to face transaction with the drawer or his agent by anyone impersonating another and drawn payable to the one impersonated and endorsed by any one else than the one impersonated. Mechanically reproduced signatures are treated the same as handwritten signatures. American Surety Company of Nem York, Banker's Blanket Bond, Standád Form No. 24 (rev. to June, 1951). Extent of insurance indicated note 90 infra.

88. Banks assess charges for checking accounts. New Haven banks charge a maintenance charge of 50 cents per month plus 8 cents for each deposit, 2 cents for checks deposited for collection on local banks, 3 cents for checks deposited on out-of-town banks, and 4 cents for each check drawn on the account. Additional charges are made for special services such as certifying check- 25 cents, stop-payment-50 cents, return depositor's check $-\$ 1.00$, check deposited and later returned unpaid-25 cents. Provisions for increasing rates are embodied in the depositor's contract approved by the American Bankers Association: "New service and maintenance charges and changes in existing charges shall become effective upon the posting of notice in the office of this bank for a period of ten days and the publication thereof in any local newspaper before the end of such period, or upon giving the depositor not less than ten days' notice in writing mailed to his last known address." Thus added costs of insurance could be passed on through these charges to the uscrs of checking accounts. See Kessler, supra note 75, at 896.

89. The cost of an insurance policy is the function of three factors-risk of loss, rate of return on insurer's investments, and administration expenses. Comment, Cost and Coverage of Industrial Life Insturance, 61 YALE L.J. 46, 50 n.26 (1952). Since the risk and rate of return are not variables, increased administration costs will lead to higher insurance rates. See $i d$. at 55 . 
collecting bank is in a position to cover so many instruments by one insurance policy. ${ }^{90}$ But even the collecting bank is not in as favorable a position as the drawee bank to pass on the cost of the protection equitably. While the collecting bank could include the expense in the charges made to transferees for

90. A study of 619 banks maintaining insurance against forgery loss on negotiable paper disclosed:

\section{Group 1:} $\$ 5,000,000$ to $\$ 7,500,000$

Group 2:

$\$ 7,500,000$ to $\$ 10,000,000$

Group 3: $\$ 10,000,000$ to $\$ 15,000,000$

Group 4: $\$ 15,000,000$ to $\$ 20,000,000$

Group 5: $\$ 20,000,000$ to $\$ 30,000,000$

Group 6: $\$ 30,000,000$ to $\$ 50,000,000$

Group 7: $\$ 50,000,000$ to $\$ 75,000,000$

Group 8:

$\$ 75,000,000$ to $\$ 100,000,000$

Group 9: $\$ 100,000,000$ to $\$ 150,000,000$

21

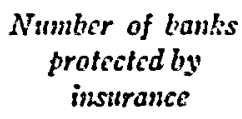

155

119

104

59

65

48

37

$$
\begin{gathered}
\text { Acerage number of } \\
\text { active checting arconsts } \\
\text { per bas? }
\end{gathered}
$$

$$
2,305
$$

2,949

3,521

4,574

5,015

6,671

8,120

22

10,775

Group 10: $\$ 150,000,000$ to $\$ 250,000,000$

Group 11 : $\$ 250,000,000$ to $\$ 500,000,000$

Group 12: $\$ 500,000,000$ up

936,194

Source: Mendenhall, Bankers Blanket Bonds Protcting Banlss Whose Deposits Exceed $\$ 5,000,000$ in Towner Rating Bureau (1943). 
handling checks for deposit, ${ }^{91}$ it is not able to shift the cost to drawers in proportion to the number of instruments they create.

Placing loss on negligent parties. Placing the loss on negligent parties is justified by considerations of equity and by the desire to enforce sound business practices. Courts have strongly responded to the appeal that where neither of two parties had actual knowledge of a forgery, "fairness" dictates that the one who carelessly contributed to the possibility of loss should sustain the loss. ${ }^{02}$ In addition, emphasis has been placed on inducing adherence to sound business practices by placing loss on those who fail to exercise a reasonable standard of care. ${ }^{93}$ It is true that judicial standards developed in forgery cases only partially induce careful conduct. Other factors such as a desire to avoid the inconvenience and loss from taking checks drawn on insufficient funds may equally prompt parties to exercise care, for example, in requiring identification from check transferors. And entirely aside from forgery negligence doctrines, parties may simply desire to conform to existing conceptions of proper business methods. Nevertheless, there is ample evidence that standards of conduct developed in forgery cases do substantially affect behavior in the business world.

Two distinct types of negligence doctrines are available to adjust loss according to negligence. On the one hand, doctrines may be based on reasonable conduct and embody sufficient flexibility to allow the decisions to turn on the

91. Banks do make a charge for collecting checks deposited in checking accounts. See note 88 supra. However, no similar charges are generally made for checks deposited for collection in savings accounts.

92. See Royal Indemnity Co. v. Federal Reserve Bank, 38 F. Supp. 621 (S.D. Ohio 1939), aff'd, 119 F.2d 778 (6th Cir. 1941) (where 3d person's fraud results in loss, party who first reposed confidence must bear loss) ; Keck v. Browne, $314 \mathrm{Ky} .151,234$ S.W.2d 183 (1950) (place loss on negligent drawer in interest of fairness); see note 76 supra.

93. See, e.g., Defiance Lumber Co. v. Bank of Cal., 180 Wash. 533, 41 P.2d 135 (1935) (use of payroll procedures capable of being padded); Couture v. Ocean Park Bank, 205 Cal. 338, $270 \mathrm{Pac}$. 943 (1928) (ambiguous instrument construed against drawer); Goodyear Tire \& Rubber Co. v. First Nat. Bank of Denver, 95 Colo. 34, 32 P.2d 268 (1934) (not taking audit to discover reason for losses); Bartlett v. First Nat. Bank, 247 III. 490, 93 N.E. 337 (1910) (permitting agent to endorse checks in customers' names made drawer liable) ; Erickson Co. v. Iowa Nat. Bank, 211 Iowa 495, 230 N.W. 342 (1930) (inadequate supervision of employees); Herbel v. Peoples State Bank of Ellinwood, 170 Kan. 620, 228 P.2d 929 (1951) (place loss on negligent drawee bank to enforce good banking practice despite depositor's subsequent negligence); Bank of Williamson $v_{\text {. McDowell }}$ County Bank, 66 W. Va. 545, 66 S.E. 761 (1909) (drawee bank did not have a signature of its depositor on file to compare against checks).

Publications of the Secret Service directed to small businessmen who cash checks emphasize that the person who cashes the check is the ultimate loser if endorsement is forged. They outline the proper precautions to follow. U.S. SECRET SERvicE, KNow Your MONEY 29-31 (1951). One commentator suggests that the lesson of the rule applied in the case of the forged endorsement is that one should never take a check from a stranger. This is considered sound business practice. Kessler, Forged Endorsements, 47 YALE L.J. 863, 888 (1938). See also Britron, Brlls axi Notes \& 143 (1943). 
facts of the particular case. These doctrines may require complicated hw: suits and entail uncertainty in attempting to forecast the outcome of trials. However, uncertainty and complexity will be mitigated as case law develops concepts of what constitutes prudent conduct. The flexible doctrines allow allocating loss to negligent parties in every case and secure freedom for the law to adjust to changing business conditions and practices through the years. Alternatively, the complexity and uncertainty of lawsuits can be reduced at the sacrifice of precise justice if automatic doctrines are chosen which are based on an approximation of the party who is usually negligent. Since these doctrines are applied without regard to the particular facts of the case, the scope of the courts' inquiry can be narrowed, and certainty is promoted." This increased predictability promotes out-of-court settlements-an important advantage in the commercial world. One difficulty experienced with the automatic standard is that "hard" cases frequently produce exceptions to the general rule. Then the uncertainty of whether a case will be classified as within the general rule or the exception is introduced. Or if exceptions are not created, then loss is placed on parties who are not in fact negligent. The extent to which this takes place rests on the accuracy of generalizing as to when negligence occurs and contributes to loss in various types of situations.

Uniformity. Uniformity in the application of the doctrines which promote transferability, place the loss on the best risk bearer, and place loss on negligent parties, is essential if these doctrines are to perform their functions. Doctrines applied differently in similar circumstances, of course, indicate deviations from achieving desired objectives in at least one of the situations. But more directly, uniformity provides predictability. ${ }^{95}$ Consequently, it enables parties to adjust their behavior to establish standards by indicating who should insure or what conduct is considered careless. And additionally, uniformity is necessary to produce the equality of treatment of parties in similar circumstances that fairness requires.

Attainment of uniformity may entail establishing a consistent preference of one objective over another. Promoting transferability and placing the loss on the best risk bearer do not produce conflicting results. ${ }^{30}$ But where parties are negligent, placing the loss on the negligent party may conflict with results consistent with other objectives. In deciding whether a negligent drawer or a non-negligent drawee bank is to bear loss, for example, placing loss on the

94. As Justice Brandeis has pointed out, in cummercial law "it is more important that the applicable rule of law be settled than that it he settled right:" Sre Burnet $y$. Coronado Oil \& Gas Co., 285 U.S. 393, 406 (1932) (dissent). Suggesting the desirability of automatic standards are Comment, 18 U. of CHI. L. Rer. 281, 286 (1951); Nivte, 50 COL. L. Rev. S02, S04 (1950).

95. This is particularly true because out-of-jurisdiction law may be applieable by conflict of law dactrines. See United States v. Guaranty Trust Co., 293 U.S. 340 (1934); Swift \& Co. v. Bankers Trust Co., 280 N.Y. 135, 19 X.E.2d 992 (1939).

96. This is so because both policies can be served by placing the lass un drawee banls. 
negligent drawer does not result in the best risk bearer's sustaining liability ${ }^{07}$ Or in deciding whether a negligent taker from the forger or a non-negligent true owner should carry the loss, selection of the negligent party would conflict with the result dictated by desire to promote transferability.

\section{Failure of Law to Realize Objectives}

Allocation According to Type of Forgery. Differentiation in ultimate liability based on the type of forgery frequently frustrates appropriate objectives for loss allocation. Perhaps the clearest method of illustration is by analysis of typically recurrent fact situations.

Assume, for example, that a forger enters a store, selects mechandise, presents bogus identification, and pays with an invalid instrument. The merchant endorses the check, deposits it at his bank, and the instrument is sent through the banking system for collection. After payment by the drawee bank, the forgery is discovered. Following the general mechanical rules: if the drawer's signature was forged, the drawee will sustain the loss under the forged check rule $;^{98}$ but if the forger falsified an endorsement ${ }^{90}$ or altered the payee's name and endorsed the substituted name, ${ }^{100}$ loss will fall on the merchant.

Loss allocation geared to the type of forgery does not serve the goal of placing loss on negligent parties. The rules are frequently defended as placing loss on parties who are probably negligent in different forgery situations. But there is no negligence basis for treating the same party differently as the type of forgery differs. ${ }^{101}$ The merchant, for example, is usually no more negligent in accepting a check with a forged endorsement or artful alteration than in accepting a forged check. In both cases he identifies the last signature as being that of the person who presents the check to him, and he can not know whether the presenter has previously forged either an endorsement or a

97. See discussion in Note, Liability of Drazce Paying on Forged Indorsement, 20 ConN. B.J. 215, 218 (1952).

98. See Railway Express Agency v. Bank of Philadelphia, 168 Miss. 279, 150 So، 525 (1933) ; National Bank of Rolla v. First Nat. Bank of Salem, 141 Mo. App. 719, 125 S.W. 513 (1910) ; First Nat. Bank of Cottage Grove v. Bank of Cottage Grove, 59 Ore. 388, 117 Pac. 293 (1911) (more care in limiting to facts). See also cases cited notes 17, 47 supra.

99. The drawee bank can recover from the collecting bank who in turn recovers from the merchant. See Hartford-Connecticut Trust Co. v. Riverside Trust Co., 123 Conn. 616, 197 Atl. 766 (1938) ; Merchants' Nat. Bank v. Federal State Bank, 206 Mich. 8, 172 N.W. 390 (1919) ; Citizens Bank of Hattiesburg v. Miller, 194 Miss. 557, 11 So.2d 457 (1943); cf. National Bank of Commerce v. First Nat. Bank of Cowcta, 51 Okla. 787, 152 Pac. 596 (1915). See cases cited notes 5, 9, 21, 22 supra.

100. As previously pointed out in notes 32,35 supra, there is a split in cases; most allow the drawee to recover from the collecting bank.

101. Conpare, e.g., Kenneth Investment Co. v. National Bank of Republic of St. Louis, 96 Mo. App. 125, 70 S.W. 173 (1902) (drawee not protected), with Leather Manufacturers' Bank v. Morgan, 117 U.S. 96 (1885), and Myers v. Southwestern Nat. Bank, 193 Pa. 1, 44 Atl. 280 (1899) (drawee wins). 
drawer's signature. ${ }^{102}$ And where the last signature is the forgery, the same type of documents induce the merchant to believe that the forger is either a purported drawer or endorser. Similarly, the drawee bank is usually not negligent in failing to discover either a forged endorsement or a forged drawer's signature. Courts have recognized that a drawee is not negligent if it fails to examine endorsements for their validity, ${ }^{103}$ even though it may have a signature of an endorsee in its possession with which to compare the endorsement. ${ }^{104}$ This recognition is grounded in the belief that a standard of care requiring the drawee to examine the numerous signatures on each checli is both unrealistic and unreasonable, and that successful forgery exists despite the practice of most banks in conducting some examination of the endorsements. ${ }^{105}$ Since the modern bank processes thousands of checks daily, ${ }^{100}$ it is virtually as unrealistic to consider a drawee bank negligent for failure to discover a forged drawer's signature. ${ }^{107}$

102. Compare Cowan v. Thompson, 25 Tcmn. App. 130, 152 S.W.21 lo3t (1941) (previous forged signature was of drawer), atith cases imvolving pretiuus furged endorsement signatures: c.g. National Bank of Detruit v. Fidelity \& Degrosit Co. of MId. 291 Mich. 36, 288 X.W. 325 (1939); Prugh, Cumbsst \& Land v. Linwusd State Banli, - Mo. - 241 S.W.2d $\$ 3$ (1951): United States Guaranty Co. v. Hamilton Nist. Bank, 189 Tenn. 143, 223 S.W.2d 519 (1449).

103. The law is singularly ambivalent in its requircment that the dravee ateertain the genuineness of the endorsements of prior parties. In a suit against a collecting banl: or prior party the drawee is not responsible for lnowledge of the genuineness of endorsements. Citizens of Hattiesburg r. Miller, 194 Mtiss. 557, 11 Sv.21 457 (1943); National Bank of Commerce of N.Y. r. National Mechanics' Banking Ass'n of N.Y., 55 N.Y. 211 (1873); cases cited note 104 infra. However the drawee owes the payee the duty to determine the genuineness of the endorsements. Citizens \& Southern Nat. Banl: v. Davis, 54 Ga App. 836, 18S S.E. 589 (1936) (certified check); Chamberlain MLetal Co. v. Bank of Pleasanton, 98 Kan. 611,160 Pac. 1138 (1916). And it must ascertain the validity of endorsements for the drawer's benefit. Robertson Banking Co. v. Brasfield, 202 Ala. 167, 79 So. 651 (1918); Wormhoudt Lumber Co. v. Union Banli \& Trust Co., 231 Iowa, 928, 2 N.W.2d 267 (1942); Hays v. Lowndes Savings Lianls \& Trust Co., 118 W. Va. 360,190 S.E. 543 (1937).

104. See the facts in Board of Education v. National Union Bank of Dover, 121 N.J.L. 177, 1 A.2d $3 \& 3$ (Ct. Err. \& App. 1938) (forged endorsements included that of the maker of check purportedly made out by the maker to maker's urder); Corn E. change Bank v. Nassau Bank, 91 N.Y. 74 (1883) (drawee v. cüllecting bank; no evidence allowed that practice of drawee is to check endorsements of payee).

105. For bank practice in examining endorsentents see Arserici:: Bumisers Association, Bane Tellers Do's and Don'ts 33, 34 (1952) ; Inving Trest Co., Safrguaris Against Forgeries 17, 18 (1944). See Apfenmx B infru.

106. A drawee may handle as many as 700,000 checks a day. Leary, Defcrred Postisg \& Delayed Returas-the Current Check Colletion Froblem, 62 H.ARr. L. Rev. 909 (1949). The tremendous increase in use of checks in recent years is suggested by the doubling of debits to accounts in Philadelphia from $\$ 16,000,000,000$ annually to $\$ 32,000,000,000$ aninually, in the 10-year period 1937-47. Reported in Weiner v. Pennsylvania Co., 160 Pa. Super. 320, 51 A.2d 385 (1947).

107. The original justification for the forged check rule was the drawce's negligence. Price v. Neal, 3 Burr. 1354, 97 Eng. Rep. $\$ 71$ (K.B. 1762). This requirement that the drawee 
Rules based on the type of forgery operate automatically without regard to the conduct of parties in particular cases. Thus a merchant who exercises reasonable care in identifying the party who presents the check to him will sustain the loss if a forged endorsement is successful, ${ }^{108}$ while the merchant who takes no steps to identify the transferee may be protected if the drawer's signature is forged. ${ }^{109}$ And similarly, the drawee who engaged in the unfeasible meticulous examination of each check would still bear loss when the forged drawer's signature is sufficiently clever to defy detection, ${ }^{110}$ while the drawee who failed to attempt to compare a forged endorsement with a sample signature in its files escapes liability. ${ }^{111}$ Because of the difficulty in generalizing as to which party is usually negligent, the automatic rules may serve to place the loss on a non- negligent party in many-if not a majority-of cases. But even if a generalization could be made, there seems no basis for different rules reaching opposite results according to the type of forgery.

Determination of liability according to the type of forgery may defeat other objectives for loss allocation. The forged instrument rule does promote trans-

examine and discover forgeries of the drawer's signature is firmly embodied in the present forged check rule. Frankini v. Bank of America Nat. Trust \& Savings Ass'n, 31 Cal. App.2d 666, 88 P.2d 790 (1939) ; National Bank of Rolla v. First Nat. Bank, 141 Mo. App. 719, 125 S.W. 513 (1910); Bank of Williamson v. MIcDowell County Bank, 66 W. Va. 545, 66 S.E. 761 (1909). Under modern commercial demands large banks find it virtually impossible to authenticate every check. George W. Adlam reports, "The bank has on file an authentic signature of their depositor, and if in doubt they can check with this file, and on very large items undoubtedly they do. On the vast flood of small items, particularly payroll checks, it is quite unlikely that the banks take any special precaution. Only a small part of the checks that they honor are paid directly at the tellers' windows. Thic majority of them come through clearings, that is checks paid by other banks or by stores and deposited at the bank. This of course affords a better opportunity for the bookkcepers in reconciling the accounts to check the signature file. ... [I]n certain of the large city banks like in New York and Chicago, they rarely check the signatures on items under $\$ 100$ or $\$ 200$." Communication from George W. Adlam to Yale LAw Journal, supra note 86. Banking practice is described in Note, 14 U. of CHI. L. Rev. 705, 707-8 (1947). For criticism of forged check presumption of negligence of drawee bank, see Colonial Trust Co. v. National Bank, 50 Pa. Super. 510 (1912).

108. See National Bank of Detroit v. Fidelity \& Deposit Co. of Md., 291 Mich. 36, 288 N.W. 325 (1939).

109. See Germania Bank v. Boutell, 60 Minn. 189, 62 N.W. 327 (1895); Fidelity \& Casualty Co. of N.Y. v. Planenscheck, 200 Wis. 304, 227 N.W. 387 (1929).

110. See Hilton, The Detection of Forgery, $30 \mathrm{~J}$. CRns. L. \& Cruninolocr 568, 571 (1939). "The examiner who states that he can arrive at the true nature of every disputed signature despite limiting conditions which surround some problems is not a scientist." Hilton, Science and the Scientific Examination of Signatures, 24 TuLANe L. Rev, 204, 209 (1949). See Inbau, Lay Witness Idcntification of Handwriting, 34 ILL. L. REv. 433, 438-9 (1939). Cases in which careful examination failed to discover the forgery include Worthen Bank \& Trust Co. v. Kelly-Nelson Construction Co., 219 Ark. S82, 245 S.W.2d 405 (1952); Hardy v. Chesapeake Bank, 51 Md. 563 (1879) ; Denbigh v. First Nat. Bank, 102 Wash. 546, 174 Pac. 475 (1918).

111. See cases cited note 104 supra. 
ferability by preserving the finality of payment by the drawee. And it also aids in risk distribution by placing loss on banks who may easily sustain and distribute it. Although the rules for forged endorsements and altered checks protect the drawer and thus will not impair his use of checks, they thwart transferability by increasing the risk of accepting checks as payment and, at the same time, place the loss on the merchant who is often ill-suited to bear or distribute it.112 Finally, allocation according to type of forgery clearly abnegates uniform treatment of parties who act similarly. 113

Consider now a second typical fact situation where an employee misappropriates company funds by manipulating and forging checks. He may (1) steal genuine checks from the outgoing mail of the company; (2) supply the names of fictitious payees to the person drawing the checks, and then steal these checks; (3)issue forged or unauthorized checks; or (4) write checks to fictitious payees and use them as his own. The forger then falsifies an endorsement, perhaps adds his own true name as an endorsement and obtains cash or merchandise from a bank or local merchant. The ${ }_{0}$ check is sent through the banking system for collection and the forgery is subsequently discovered. If the forger has adopted the first alternative, the forged endorsement rule places loss on the bank or merchant who talies the check from the forger. ${ }^{114}$ In the second case, some jurisdictions place loss on the employer, ${ }^{115}$ while others choose the party who talies from the

112. The forger's intended victim is usually the small merclannt. Communication from U. E. Baughman, Chief, U.S. Secret Service, to Y.1LE LAw Jounsin, Feb. 28, 1952, on file in Yale Law Library. Many storekeepers are ansious to make salcs and will talie a check when necessary to make the sale. The highly competitive position and the fair trade laws make it difficult for merchants to recoup their forgery losses hy inereased prices.

113. For unequal treatment of the merchant-taker, compore forgcd cheds cases cited note 109 supra in which the taker escapes loss, with Citizens Bank of Hattiesburg v. Mliller, 194 Miss. 557, 11 So.2d 457 (1943) ; J. C. Hackett Co. v. Simmonds, \& Oh' App. 267 , 87 N.E.2d 739 (1949), and case cited note 108 sipra. Lack of uniform troatment of tits drawee bank can be seen by comparing the forged endorsement cases citcd note 104 supro, in which the bank escapes liability, with cases cited note 110 supra.

114. Sprague v. West Hudson County Trust Co., 92 N.J. Eq. (39, 114 Atl. 34t (1921); National Surety Co. v. President and Directors of J Lauhattan Co., 252 N.Y. 247, 169 N.E. 372 (1929); Guardian Savings \& Loan Ass'n v. Liberty State Banl:, 60 S.W.2d 823 (Tex. Civ. App. 1933), aff'd, 127 Tex. 311, it S.W.2d 133 (1936); cases cited notes $20-22$ supra. However, the drawer may sustain part of the total loss if he is negligent in failing to discover the forgeries after losses have cume to his attention. Detroit Piston Ring Co. v. Wayne County \& Home Savings Bank, 253 Mich. 163, 233 N.W. 185 (1930); Scott v. First Nat. Bank in St. Louis, 343 Mio. 77, 119 S.W 2d 929 (1938). There has also been a growth in the duty imposed on the drawer to supervise his employees adequately. Goodyear Tire \& Rubber Co. v. First Niat. Banls of Denver, 95 Colo. 34, 32 P.2d 268 (1934); Defiance Lumber Co. v. Bank of Calif., 180 Wash. 533, 41 P.2d 135 (1935). But of. City of St. Paul v. Merchants' Nat. Banli, 151 Minn. 485, 187 N.W. 516 (1922).

115. See Citizens Loan \& Security Co. v. Trust Co. of Georgia, 79 Ga. App. 184, 53 S.E.2d 179 (1949), 3 VAND. L. Rev. 109 (1949); Suuthall v. Columbia Niat. Banl; 244 
forger. ${ }^{116}$ In the third situation, where the forger uses forged or unauthorized checks, loss usually falls on the drawee bank.117 Only in the fourth situation is the employer certain to sustain the loss. ${ }^{118}$

Again, allocation according to type of forgery frequently fails to place loss on negligent parties. If the employer's conduct in misplacing his trust in a dishonest employee is deemed negligent, then the law fails in not making the employer liable in all four situations, for the misplaced trust is equally operative in each. ${ }^{119}$ This failure is particularly unjustified becatuse there is no variance in the actions of the drawee bank or parties who take from the forger which justifies different treatment of them on negligence grounds. But cven if the "misplaced trust" rationale were consistently adhered to, results would still fail to place loss on negligent parties in so far as employers exercised assiduous care in placing trust and forgeries nevertheless occurred. ${ }^{120}$ On the other hand, if negligence consists of the failure of the employer to discover continued misappropriation of funds rather than in his misplacing trust, ${ }^{121}$ the law again inappropriately allocates loss. Under this rationale, the employer should not be liable for the first instruments in any series of forgeries, for in none of the four situations can the employer discover the loss caused by the

S.W.2d 577 (Mo. App. 1951) ; American Surety Co. v. Cortland Savings \& Banking Co., 143 Ohio St. 353, 55 N.E.2d 583 (1944).

116. The cases are most frequently litigated as between drawer and drawce, but when the drawee loses he can fall back down the chain of endorsements. The drawec lost in the following cases: American Sash \& Door v. Commercial Trust Co., 332 Mo. 98, 56 S.W.2d 1034 (1932); Board of Education v. National Union Bank of Dover, 121 N.J.L. 177, 1 A.2d 383 (Ct. of Err. \& App. 1938) ; Shipman v. The Bank of the State of N.Y., 126 N.Y. 318, 27 N.E. 371 (1891); Commonwealth v. Globe Indemuity Co., 323 Pat 261, 185 Atl. 796 (1936) ; Liberty Mutual Ins. Co. v. First Nat. Bank in Dallas, - Tex. -, 245 S.W.2d 237 (1951). See note 53 supra.

117. See Worthen Bank \& Trust Co. v. Kelly-Nelson Const. Co., 219 Ark. 882, 245 S.W.2d 405 (1952); Cairo Banking Co. v. West, 187 Ga. 666, 2 S.E.2d 91 (1039); Couvillon v. Whitney Nat. Bank of New Orleans, 218 La. 1096, 51 So.2d 798 (1051); Martin v. First Nat. Bank in St. Louis, 358 Mo. 1199, 219 S.W.2d 312 (1949); Newco Land Co. v. Martin, 358 Mo. 99, 213 S.W.2d 504 (1948); Maryland Casualty Co. v. Central Trust Co., 297 N.Y. 294, 79 N.E.2d 253 (1948); cases cited note 128 infra.

118. See Ellis Weaving Mills v. Citizens \& Southern Nat. Bank of Spartanburg, 91 F. Supp. 943 (W.D.S.C.), aff'd, 184 F.2d 43 (4th Cir. 1950). See cases cited 52 supra and 168 infra.

119. Compare cases cited in notes 115 and 118 , with cases in which employer escaped liability despite reliance on forger-employee: Los Angeles Investment Co. v. Home Savings Bank, 180 Cal. 601, 182 Pac. 293 (1919); Jordan Marsh Co. v. National Shawmut Bank, 201 Mass. 397, 87 N.E. 740 (1909) ; Fitzgibbons Boiler Co. v. National City Bank, 287 N.Y. 326, 39 N.E.2d 897 (1942). See cases cited note 116 supra.

120. See Defiance Lumber Co. v. Bank of Cal., 180 Wash. 533, 41 P.2d 135 (1935), especially dissenting opinion. The rule is criticized in Comment, Depositors' Dtty to Examine Bank Statements for Forged or Altered Checks, 6 ARk. L. REv. 199, 204 (1952).

121. See First Nat. Bank of Birmingham v. Allen, 100 Ala. 476, 14 So. 335 (1893); Osborn v. Corn Exchange Nat. Bank, 218 I1l. App. 28 (1920); Israel v. State Nat. Bank of Aew Orleans, 124 La. 885, 50 So. 783 (1909). 
first forgeries until after the loss has occurred.120 As to additional losses, there is some justification in negligent conduct for holding the employer liable, since he may be considered to have a duty to discover existence of forged checks by comparing his returned checks with his books. ${ }^{123}$ But then he should be liable in all four situations. ${ }^{124}$ However, even in situations where there is some justification for allocating loss to the employer, mechanical doetrine may not in fact place loss on negligent parties for it does not relate to the actual conduct of the employer in each case. IThere the dishonest employee keeps the company books. for example, the employer may not discover the forgery even by exercising considerable care; nevertheless he will he held liable. ${ }^{105}$

Allocation according to the type of forgery, as applied to misappropriations of company funds, may also fail to serve other objectives. Differences in treatment of parties who behave similarly in analogous situations defeat attainment of uniformity. ${ }^{128}$ In addition, it is symptomatic of inconsistent fulfillment of other objectives. Transferability is promoted by current doctrine which allocates loss to the employer in the fictitious payee situations, ${ }^{107}$ and to the drawee in the forged check cases. ${ }^{128}$ But where genuine checls are stolen, ${ }^{129}$ or in some fictitious payee cases, ${ }^{130}$ placing loss on the

122. Compare Scott v. First Nat. Bank in St. Louis, 343 M5o. 77, 119 S.W.2d 929 (1938) ; Detroit Piston Ring Co. v. Wayne County \& Home Savings Bank, 252 Mich 163,233 N.W. 185 (1930) (cases in which drawer loses only amount aiter time he should have discovered fraudulent scheme), rith fictitious payce cases in which drawer loses all, even the first checks, cited notes 115,118 supro. And see the appliention of the fictitious payee rule to make the drawer lose on the first cheel but win on subsequent checks. Callaway v. Hamilton Nat. Bank of Washington, 195 F.2d 556 (D.C. Cir. 1952).

123. See notes 41-43a supra.

124. See forged endorsement cases where drawer could have discovered forgery by examining checks, but did not, and was still permitted to recover. First Nat. Banl: of Atlanta v. American Surety Co., 71 Ga. App. 112, 30 S.E.2d 402 (1944); Board of Education v. National Union Bank of Dover, 121 N.J.L. 177, 1 A.2d 383 (Ct. of Err. \& App. 1938); Liberty Mutual Ins. Co. v. First Nat. Bank in Dallas, - Tex. -, 245 S.W.2d 237 (1951). Contra: Royal Indemnity Co. v. Federal Reserve Bank, 38 F. Supp. 621 (S.D. Ohio 1939), aff'd, 119 F.2d 778 (6ith Cir. 1941).

125. Whitney Trust \& Savings Bank v. Jurgens-Fuwler Cu., $1 \& 0 \mathrm{La}, 455,150$ So. 400 (1934); Myers v. Southwestern Nat. Bank, 193 Pa. 1, 4 Atl. 280 (1899); Jirst Nat. Bank of Richmond v. Richmond Electric Co., 106 V/2. 347, 56 S.E. 152 (1967). But cf. Clark v. National Shoe \& Leather Bank of N.Y., 164 N.Y. 498, 58 N.E. $65 y$ (1900) (depositor only charged with knowledge that a dishonest agent obtained by examination).

126. Compare cases cited notes 114-118 supra.

127. See cases cited notes $115,11 S$ sur ra.

128. See Greensboro Ice \& Fuel Co. v. Security Nat. Bank, 210 N.C. 24, 1\$, S.E. 362 (1936) ; R. H. Kimball Inc. v. Rhode Island Hospital Nat. Banl, 72 RI. 144, 48 A.2d 420 (1947) ; Denbigh v. First Nat. Bank, 102 Wash. 546, 174 Pac. 475 (1918); and cases cited note 117 surra.

129. See cases cited note 114 supra.

130. See cases cited note 116 supra. 
merchant or bank who take from the forger directly thwarts transferability On the other hand, placing loss on the drawee bank promotes sensible risk distribution. ${ }^{131}$ And even placing loss on the employer partially aids pursuit of the same goal because of a company's ability to bond its employees. ${ }^{132}$ But again liability for the taker from the forger frustrates this objective. ${ }^{103}$ In

131. See cases cited note 117 supra, and discussion in notes 87-90 supra.

132. For suggestions of this policy see Comment, Fictitious Payee and the U.C.C., 18 U. OF CEI. L. REv. 281 (1951); Note, Liability of Bank for Frauls of Depositor's Employee, 14 U. of CHI. L. Rev. 705 (1947). The fallacy in this approach is the added cost of multiple policies and duplicating insurance against the same risk since the depositor's forgery bond also indemnifies the bank. See note 89 stpra. If the drawee bank insured against the loss and passed on the cost of the protection in proportion to the number of checks issued, the large user of checks pays commensurately for his protection. The Depositors' Forgery Bond insures against forgery or alteration of any check made by or drawn upon the insured or made by one acting or purporting to act as agent of the insured, regardless of whether the endorsement is a forgery within the law of the place controlling the construction thereof. The bond's coverage includes any check drawn in the name of the insured, payable to a fictitious payee and endorsed in the name of such fictitious payee; any check procured in a face-to-face transaction with the insured by anyone impersonating another and drawn payable to the one impersonated; and any payroll check drawn by the insured payable to bearer as well as to a named payee and endorsed by anyone other than the named payee without authority from the payee. Mechanically reproduced facsimile signatures are treated the same as handwritten signatures. The underwriter further indemnifies any bank in which the insured carries a checking or savings account against losses sustained through any of the described types of forgery or alteration. American Surety Company of New York, Depositors Forgery Bond (rev. to Feb. 1, 1948).

Rates charged for bonds are:

$\begin{array}{ccr}\text { Amount of Bond } & 1 \text { year } & 3 \text { years } \\ \$ 1,000 & \$ 7.50 & \$ 9.39 \\ 5,000 & 18.75 & 46.88 \\ 10,000 & 37.50 & 93.75 \\ 25,000^{*} & 75.00^{*} & 187.50^{*} \\ 50,000^{*} & 131.25^{*} & 328.13^{*} \\ 100,000^{*} & 237.50^{*} & 593.75^{*}\end{array}$

* Premiums subject to discount for good experience.

American Surety Company, Depositors Forgery Bond-Coverage and Rates (rey. April 1, 1948).

One possible way of handling embezzlement schemes when the depositor is insurce is to hold that collection from the insurance company is an election of remedies and the insurance company then has no action against the drawee. United States Fidelity \& Guaranty Co. v. First Nat. Bank in Dallas, 172 F.2d 258 (5th Cir. 1949) ; United States Fidelity \& Guaranty Co. v. Fidelity Nat. Bank \& Trust Co., 232 Mo. App. 412, 109 S.W.2d 47 (1937). However the majority view is contra. Tarrant American Savings Bank v. Smokeless Fuel Co, 233 Ala. 507, 172 So. 603 (1937) ; First Nat. Bank of Atlanta v. American Surety Co., 71 Ga. App. 112, 30 S.E.2d 402 (1944); Grubnau v. Centennial Nat. Bank, 279 Pa. 501, 124 Atl. 142 (1924); Liberty Mutual Ins. Co. v. First Nat. Bank, - Tex، -, 245 S.W.2d 237 (1951).

133. See note 112 supra. 
short, allocation according to type of forgery leaves attainment of desired goals at the mercy of the forger's conduct.

Allocation Miodified by Negligence Doctrines. In recent years courts have placed increasing emphasis upon holding liable parties whose negligence contributed to forgery losses. As a result, negligence doctrines have been introduced to modify allocation according to the type of forgery. 134 While in many situations these doctrines serve more effectively than rules based on type of forgery to place loss on negligent parties, ${ }^{135}$ they are nevertheless defective in several respects.

Some negligence doctrines imposing loss on the drawer have hardened into absolute rules of liability presenting a twofold inadequacy in allocating loss to negligent parties. This is true, for example, of the "impostor"130 and fictitious payee rules, ${ }^{137}$ and of statutes limiting the drawer's right to recovery if he fails to notify the bank of a forgery within the statutory time period.s. Since loss is imposed on the drawer without regard to his conduct in any particular case, he will be liable even though he has exercised reasonable care. ${ }^{139}$ And even where other parties are negligent and the drawer is not, he may nevertheless sustain loss..$^{140}$

Existing negligence doctrines are also inadequate in allocating loss to negligent parties because courts refuse to invoke them in many situations. The drawee bank that pays a forged check, for example, is liable under the forged check rule. ${ }^{141}$ When a collecting bank has been negligent in handling the

134. This can be seen in the depositor's duty to his bank in the case of forged instruments. Compare Weisser's Administrators v. Denison, 10 N.Y. 68 (1854) (depositor owes no duty to bank), with Critten v. Chemical Nat. Bank, 171 N.Y. 210, 63 N.E. 969 (1902) (duty to exercise reasonable care to verify vouchers by record of checks issued). In regard to development of drawer's duty to report furged endorsements see Britton, Bilus and Notes 672 (1943).

135. See, e.g., cases cited notes $45,57,58,64,65$ supra.

136. See notes $48-50$ supra.

137. See notes 51-4 supra.

138. See notes 39,40 supra.

139. E.g. Santa Maria v. Industrial City Bank \& Banking Co., 326 Mass. 440, 95 N.E.2d 176 (1951) (impostor rule puts loss on prudent merchant); Equitable Life Ins. Soc. v. National Bank of Commerce, 181 S.W. 1176 (A10. App. 19l6) (fictitious payee rule imputes knowledge of dishonest employee to employer): Stump v. Banls of N.Y., 212 App. Div. 608, 209 N.Y. Supp. 396 (1st Dep't 1925) (depositor who examined cheels and compared them with stubs and balance, liable). See cases cited note 125 stpro and 140 infra.

140. E.g. Childs v. Empire Trust Co. 54 F.2d 981 (2d Cir. ), cort. den.. 206 U.S. 354 (1932) (fictitious payee rule places loss on innucent creditors when banls talkes checls from trustee under questionable circumstances).

141. Deposit Bank of Georgetown v. Fayette Nat. Bank, $90 \mathrm{Ky} .10$ (1590); Commercial \& Farmers Nat. Bank v. First Nat. Bank of Baltimore, 30 Ird. 11 (1869); Eank of St. Albans v. Farmers \& Jiechanics Bank, $10 \mathrm{Vt} .141$ (1838); and see cases cited notes 17,98 supra. 
check, some courts permit the drawee to shift its loss to the negligent party.142 But in many jurisdictions the collecting bank's negligence does not affect the drawee's liability. ${ }^{143}$ In different fact situations many states also disregard the negligent conduct of the drawer in adjusting loss. ${ }^{144}$ Finally, a negligent party may escape liability because litigants are not permitted to raise the issue of the negligence of one who is not before the court, ${ }^{145}$ while at the same time the losing litigant may have no cause of action against the negligent party ${ }^{140}$

Current use of negligence doctrines also fails to secure uniformity and so provides neither a guide for conduct nor equal treatment of parties who act similarly. Courts disagree in determining when negligence doctrines apply and in their effects on loss allocation. ${ }^{147}$ For example, a drawer's failure to discover and report a forgery may not make him liable at all, ${ }^{148}$ or it may make him liable only for the loss due to his failure, ${ }^{140}$ or it may create liability for the total loss. ${ }^{150}$ At the same time, there is variance in the concept

142. Security Commercial \& Savings Bank of San Diego v. Southern Trust \& Commerce Bank, 74 Cal. App. 734, 241 Pac. 945 (1925); National Park Bank v. Ninth Nat. Bank, 46. N.Y. 77 (1871); Johnson v. Commercial Bank, 27 W. Va. 343 (1885) ; cf. State Bank of Chicago v. First Nat. Bank of Omaha, 87 Neb. 351, 127 N.W. 244 (1910) ; and see cases cited notes 45,46 stipra.

143. Howard v. Mississippi Bank, 28 La. Ann. 727 (1876); Commercial \& Farmers' Bank of Baltimore v. First Nat. Bank of Baltimore, 30 Md. 11 (1868); Railway Express Agency v. Bank of Philadelphia, 168 Miss. 279, 150 So. 525 (1933); State Bank v. Cumberland Savings \& Trust Co., 168 N.C. 605, 85 S.E. 5 (1915); Cherokce Nat. Bank v. Union Trust Co., 33 Okla. 342, 125 Pac. 464 (1912) ; Bank of St. Albans v. Farmers' Bank, $10 \mathrm{Vt} .141$ (1838); Bank of Williamson v. McDowell County Bank, $66 \mathrm{~W}$. Va. 545, 66 S.E. 761 (1909).

144. The rationale is that the negligence is not proximate. See Jordan Marsh Co. v. National Shawmut Bank, 201 Mass. 397, 87 N.E. 740 (1909); and cases cited note 59 supra.

145. See cases cited notes 47,67 supra.

146. See note 68 supra.

147. In addition to the examples cited in the text see varying application of the impostor rule at note 48 supra, the fictitious payee rule at note 53 supra, and see also note 38 supra.

148. R. H. Kimball Inc. v. Rhode Işland Hospital Nat. Bank, 72 R.I. 144, 48 A.2d 420 (1946). See also National Bank of Commerce v. Tacoma Mill Co., 182 Fed. 1 (9th Cir. 1910).

149. See First Nat. Bank of Birmingham v. Allen, 100 Ala. 476, 14 So. 335 (1893); Bank of Black Rock v. B. Johnson \& Son Tie Co., 148 Ark. 11, 229 S.W. 1 (1921); Janin v. London \& San Francisco Bank, 92 Cal. 14, 27 Pac. 1100 (1891); Israel v. State Nat. Bank of New Orleans, 124 La. 885, 50 So. 783 (1909); Deer Island Fish \& Oyster Co. v. First Nat. Bank of Biloxi, 166 Miss. 162, 146 So. 116 (1933); Critten v. Chemical Nat. Bank, 171 N.Y. 219, 63 N.E. 969 (1902) ; Johnson v. Nat. Bank of Beaver Falls, 367 Pa. 459, 81 A.2d 95 (1951); Atlas Metal Works v. Republic Nat. Bank, 176 S.W.2d 350 (Tex. Civ. App. 1944).

150. Union Trust Co. v. Soble, 192 Md. 427,64 A.2d 744 (1948); Mlorgan v. United States Mortgage \& Trust Co., 208 N.Y. 218, 101 N.E. 871 (1913); Murry v. Real Estate Ins. Co., $39 \mathrm{~Pa}$. Super. 438 (1909). 
of the required causal relation between negligence and the forgery loss. ${ }^{151}$ One of many examples is the case of negligent mailing by the drawer. He may or may not sustain loss because courts differ in deciding whether the intervening criminal act of the forger breaks the causal relationship. 182 Standards of care, such as required measures to identify transferees, also differ widely from state to state. ${ }^{153}$ And in the case of standards for discovering forgeries, decisions vary even within a single jurisdiction. ${ }^{15 t}$ Because of the widespread movement of negotiable instruments, conflicting opinions are particularly unsettling, for the extraterritorial effect of alternate views further hampers uniformity within the confines of a jurisdiction. ${ }^{15 \pi}$

The introduction of negligence doctrines frequently thwarts attainment of other objectives in loss allocation. Transferability is hampered where loss is placed on a collecting bank negligent in handling forged chechs, ${ }^{156}$ or where takers from forgers are held liable for failure to exercise sufficient care in identifying the forger. ${ }^{157}$ Moreover, most modifications based on negligence

151. E.g.. causal relationship of: (1) negligent sunervision of cmpluyees, campare notes 58 and 59 supra, and see note 63 supra: (2) negligent drawing of checl leading t.. an alteration making drawer liable, Glasswell Develogment Cn. v. Citizens' Nat. Lant:, 191 Cal. 375. 216 Pac. 1012 (1923); Gutfrcund v. Enst River Nat. Bank, 251 X.Y. 5\%, 167 N.E. 171 (1929); not making drawer liahle, Citizens Banls of Murchead v. Niclicll, 277 Ky. 424, 126 S.W.2d 820 (1939) : First Nat. Bank v. Keldhum, 6S Otsla. 104, 172 Pac. S1 (1918); Glasscock v. First Nat. Bank, 114 Tex. 207, 2u6 S.W. 820 (1924); (3) negligent leaving of blank signed checks accessible which were eashed with forged endorsement bars recovery by drawer, Weiner v. Pennsylvania Co., $160 \mathrm{~Pa}$. Super. 320, 51 A.2d 385 (1947). Confra: Martin v. First Nat. Bank in St. Louic, $3 \times 5$ Mo. 11 19,210 S.W.2d 312 (1949). See notes 64,65 supra.

152. See note 57 supra.

153. See note 46 supra. As to differences in standards whore a sulervicing cmployse issues forged checks, comparc Myers v. Southwestern Nat. Bank, $193 \mathrm{~Pa}$. 1, H4 .1tl. $2 \mathrm{s0}$ (1899) (employer loses), aith Kenneth Investment Co. v. National Ranl of Republic, 96 Mo. App. 125, 70 S.W. 173 (1902) (employer wins); Denbiglt v. First Nat. Pants, $102 \mathrm{~W}_{3} \mathrm{~h}$.

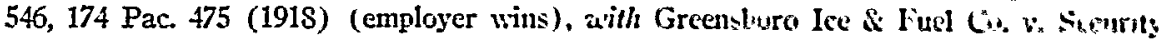
Nat. Bank, 210 N.C. 244, 186 S.E. 362 (1936) (employer rce wers part of loss).

154. On length of time in which depositor must give notice to bank, compare Johnum v. First Nat. Bank of Beaver Falls, 367 Pa. 459, 81 .1.2d 95 (1951) (rceovery where no authoritative notice until three months after forgery), aith Lesley v. Ewing, 249 Pa. 135, 93 Atl. 875 (1915) (estopped after two months); Connors v. Old Forge Discount \& Deposit Bank, $245 \mathrm{~Pa}$. 97, 91 Atl. 210 (1914) (estopped after six wedks); Knights of Joseph Building \& Loan Ass'n v. Guaranty Trust \& Safe Deposit Co., 69 P3. Super. 89 (1918) (estopped after five weeks). On the duty of the depositor to esamine returned checks, compare Takenaka v. Bankers' Trust Co., 132 Mise. 322, 239 N.Y. Supp. 459 (Sup. Ct. 192S) (examination of returned vouchers with check book sufficient even though forgery scheme not discovered), with Stumpp v. Bank of N.Y., 312 App. Div. 608, 209 N.Y. Supp. 396 (1st Dept. 1925) (comparison of checks with stubs not sufficient).

155. See, c.g., Swift \& Co. v. Bankers Trust Co., 200 N.Y. 135, 19 N.E 992 (1939) (Illinois amendment of the NIL applied in New York court).

156. See notes 45,142 supra.

157. See, e.g., Citizens" Bank of Fayette v. J. Blach \& Suns, 22S Ala. 240, 153 So. 404 (1934); J. C. Hackett Co. v. Simmonds, 84 Ohio App. 467,87 N.E.2d 739 (1949); 
shift loss to parties other than the drawee bank ${ }^{158}$ and therefore frustrate the objective of placing the burden on the best risk bearer. ${ }^{150}$ Consequently, these decisions can only be justified if placing loss on negligent parties is deemed paramount to promotion of transferability and selection of the best risk bearer. However, courts apparently have not considered establishing a consistent priority of objectives. As a result there is an inexplicit or even unconsciots choice of one goal at the sacrifice of another, and, additionally a concomitant lack of uniformity.

Allocation Modified by Availability of Defenses. Modifications introduced in loss allocation because of the peculiar availability of defenses defeats all sensible objectives. Gearing loss allocation to negligence is blatantly thwarted when one party, by waiving a defense, can immunize a negligent person from attack of others who must then bear the loss. ${ }^{160}$ And a like frustration of the negligence objective occurs by the law's refusal to consider the negligence issue an appropriate plea for particular parties, even when the negligent person is before the court. ${ }^{161}$ Moreover, since the results of the availability of defenses are largely unintended, their use may frustrate other objectives as well. Transferability may be aided when loss is precluded from falling on one who takes from a forger or on the collecting bank, ${ }^{162}$ but just as frequently the opposite result occurs. ${ }^{163}$ Moreover, since the defenses usually operate to shift loss away from the drawee bank, ${ }^{164}$ attaining the goal of risk distribution rests

Massachusetts Bonding \& Ins. Co. v. Pittsburg Pipe \& Supply Co., 135 S.W.2d 818 (Tex. Civ. App. 1940).

158. See note 15 supra. But most states do not permit the drawee to take advantage of the negligence of other parties if it was negligent itself. See American Hominy Co. v. Millikin Nat. Bank, 273 Fed. 550 (S.D. Ill. 1920) ; Union Tool Co. v. Farmers' \& Merchants' Nat. Bank, 192 Cal. 40, 218 Pac. 424 (1923); Herbel v. People's State Bank of Ellinwood, 170 Kan. 620, 228 P.2d 929 (1951) ; Kasnowitz v. Manufacturers' Trust Co., 171 Misc. 545, 13 N.Y.S.2d 211 (Sup. Ct. 1939) ; R. H. Kimball, Inc. v. Rhode Island Hospital Nat. Bank 72 R.I. 144, 48 A.2d 420 (1946); McCormick v. Rapid City Nat. Bank, 67 S.D. 586, 297 N.W. 39 (1941); Wussow v. Badger State Bank of Milwaukee, 204 Wis. 467, 234 N.W. 720 (1931). See note 44 supra.

159. See notes 87-90 supra.

160. E.g., when the drawee bank waives its defense against a drawer who negligently delayed in notifying the bank of an invalid check, a non-negligent collecting bank must repay the drawee and in turn fall back on the taker from the forger. The taker bears the loss without regard to his negligence. See cases cited note 67 supra. Also the taker bears ultimate liability if the collecting bank should refund payment on a forged check to a negligent drawee bank. See note 70 supra.

161. E.g., where a negligent taker is involved in transactions which produce a sult between collecting and drawee banks on a forged check, the inability of the drawee to assert the negligence of the taker will bar his recovery against the collecting bank, although if the collecting bank lost it could have in turn recovered from the negligent taker. Sce First National Bank of Portland v. United States Nat. Bank of Portland, 100 Ore. 264, 197 Pac. 547 (1921), and notes 47, 70 supra.

162. See discussion note 161 supra.

163. See discussion note 160 supra.

164. See note 15 supra. 
entirely on the peculiar variance in their availability. At the same time uniformity of treatment of different parties who act similarly, or the same party. who acts analogously in different cases, is clearly stymied. ${ }^{160}$ In short, the self interest of parties in waiving defenses or choosing defendants determines the attainment of desired objectives.

\section{Existing Profosals for Change}

Dissatisfaction with current law has prompted suggestions for change. ${ }^{16 s}$ The Fictitious Payee Act and the Payment of Forged or Raised Checl Act, already enacted in many states, offer changes directed at specific areas in existing law. On the other hand, the Uniform Commercial Code embodies changes in the methods of allocating forgery losses as part of an overall recodification of the current Negotiable Instruments Law.

\section{Proposed Amendments to the Negotiable Instrumcnts Lan'}

Fictitious Payee Act. This Act, in some fictitious payce situations, makes the drawer liable where current law usually places loss on the party taling from the forger. ${ }^{167}$ Prior to the Act, an employer-drawer was liable when his dishonest employee drew extra checks to fictitious payees and appropriated them to his own use; ${ }^{168}$ but when the dishonest employee was one who pre-

165. Compare, c.g., the position of the drawer in Manufacturers' lank of Cohoes v. Prudential Ins. Co. of America, 102 Misc. 339, 168 N.Y. Supp. 913 (Sup. Ct. 1918) (drawer who did not give timely notice of forgery is protected), arith Shattucls $v$. Guardian Trust Co. of New York, 204 N.Y. 200, 97 N.E. 517 (1912).

166. Despite the fact that the shortcomings of the present law reduund to the detriment of the entire business community, proposed changes have come primarily from lanking organizations. The American Bankers Association, for example, has an active committce on state legislation. This is understandable because of the great interest the banks have in the problem of forgery losses. While individual business concerns or private parties will seldom, if ever, be confronted with a forgery loss, banks must be cuntineally alurted against the possibility. The absence of demand for change from other segments of the commercial world, then, is probably due to the insignificance of the problem to any one member rather than to satisfaction with the status quv.

167. The Fictitious Payee Act amends NIL $\S 9(3)$ to provide that an instrument is made payable to bearer "when it is payable to the order of a fictitious or nunexistent or living person not intended to have any interest in it, and sucin fact was lnown to the person making it so payable, or knoan to his cmployee or other aycnt sho susplies the name of such payee." (Emphasis supplied to indicate anendment.) The Aet has been adopted in Alabama, Arizona, California, Geurgia, Idaho, Illinuis, Louisiana, Massachusetts, Missouri, Montana, New Mexico, North Carolina, Oregon, West Virgina, Wisconsin and Wyoming. For interpretation, see Citizens Loan \& Security Co. v. Trust Co. of Georgia, 79 Ga. App. 184, 53 S.E.2d 179 (1949) ; Houghton-Mliftlin Co. v. Continental Illinois Nat. Bank \& Trust Co., 293 Ill. App. 423 (1938) ; Swift \& Co. v. Bankers Trust Co., 280 N.Y. 135, 19 N.E. 2d 992 (1939).

168. Childs v. Empire Trust Co., 54 F2d 981 (2d Cir.), cert. dent, 22u U.S. 554 (1932); Bartlett v. First Nat. Bank of Chicago, 247 Ill. 490,93 N.E. 337 (1910) ; Bourne v. Maryland Casualty Co., 185 S.C. 1, 192 S.E. 605 (1937). See cases cited note $\$ 2$ suspro. 
pared accounts and "padded" them with fictitious payees while an honest employee drew the checks on the basis of the accounts, the taker from the forger ultimately sustained loss. ${ }^{100}$ The Fictitious Payee $\Lambda$ ct places loss on the employer-drawer in this latter situation as well. ${ }^{170}$

The proposed reform achieves more desirable results than existing law, but is nevertheless imperfect. Justification for the Act may be found in promotion of transferability through decreasing the possibility that the taker from the forger will assume risks in taking checks. Furthermore, as between the taker and the drawer, the latter is in a better position to insure against loss by bonding his employees and absorbing or passing on the insurance as part of his total business expense. ${ }^{171}$ But placing loss on the drawee rather than the drawer would have promoted transferability just as well, and, at the same time, would have obtained even better risk distribution. ${ }^{172}$ No justification for the Act, however, can be found in the objective of allocating loss to negligent parties. Employers who are the victims of embezzlement schemes are not necessarily negligent in failing to detect or prevent the crime; and loss may just as readily be facilitated by a negligent taker from the forger. ${ }^{173}$ Thus at fixed standard of liability predicated on probabilities of negligence is inappropriate here because of the inaccuracy of generalization as to where negligence contributing to loss most frequently occurs. And since the Act precludes the operation of exceptions which will allocate loss to parties proven negligent in particular cases, it will in fact defeat the goal of gearing loss to negligence.

Universal adoption of the Act naturally promotes uniformity of doctrine. And the Act further promotes uniformity of treatment for parties who act similarly inasmuch as it abolishes a distinction in loss allocation grounded upon the particular employee who was dishonest. ${ }^{174}$ However, in the context of forgery cases generally, the Act suffers from its narrow scope and consequently cannot bring about complete equality of treatment for parties behaving similarly. For example, employers, in cases of fictitious payee checks sustain loss under the Act while employers victimized by forged checks are protected. ${ }^{170}$ Ideally, the fictitious payee situation should be treated at least as part of the entire problem of misappropriation of company funds through activities of dishonest employees.

The Payment of Forged or Raised Check Act. The Forged or Raised Check Act makes drawers liable for failure to discover and report to the drawee bank

169. See cases cited notes 53, 116 supra.

170. Southall v. Columbia Nat. Bank, 244 S.W.2d 577 (Mo. App. 1951). See cases cited notes 53, 115, 167 supra.

171. See discussion note 132 supra.

172. See notes $87-90$ supra.

173. See the court's attitude in J. C. Hackett Co. v. Simmonds, 84 Ohio App. 467, 87 N.E.2d 739 (1949) (denying application of impostor rule which would place loss on drawer, and placing loss on taker from the forger).

174. Compare the cases cited in notes 53, 116 supra in which drawer wins, with cases cited in notes 52, 115 supra in which drawer loses.

175. See cases cited in notes 117,128 supra. 
within a required period of time, raised (i.c., where the amount is altered) or forged checks. ${ }^{176}$ Thus a drawee bank which has debited the drawer's account for a forged check may now be protected. ${ }^{177}$ And the talker from the forger who received money on a raised check no longer sustains loss for the amount of the alteration. ${ }^{178}$

This Act is hardly an improvement over existing law. In its application to the raised check, the Act does improve transferability and risk distribution by shifting loss from the taker to the drawer. ${ }^{179}$ In the more frequent forged check cases, however, transferability is already well secured by existing law which places loss on the drawee bank who pays on the check. ${ }^{189}$ Here the Act actually thwarts the most efficient risk distribution by substituting the drawer as risk bearer. ${ }^{181}$ Supporters of the new legislation justify placing loss on the drawer for his negligence in not discovering and reporting the fraudulent check. But the Act will not serve the goal of allocating loss on a negligence basis in fairly frequent situations. Under the Act the drawer will be held liable, for example, where he has, without negligence, entrusted a dishonest employee with the verification of checks, and the employee fails to report the invalid check in order to cover his earlier act of creating it. ${ }^{182}$. Ind in situations such as this, loss will rest on the non-negligent draver irrespective of the negligence of other parties associated with the instrument. ${ }^{1 \varsigma 3}$

176. The Act (with differing time limits) has hecn passed in 37 states. The exception, are Arkansas, Colorado, Delaware, Indiana, Kentucly, Maryland, Mississippi, New Hampshire, South Carolina, Tennessee, and Vermunt.

177. See cases cited note 40 supra.

178. The taker would not bear the loss in those jurisdictions which did not permit the drawer to sue the taker directly. Ste California Mill Supply Co. v. Banls of America, 3t Cal.2d 334, 223 P.2d $\$ 49$ (1950) : First Nat. lank of Blooningdale v. North Jersey Trust Co., 18 N.J. Misc. 449, 14 A.2d 765 (Sup Ct. 1940) ; Lavanier v. Cosmorolitan Banls \& Trust Co., 36 Ohio App. 285, 173 N.E. 216 (1929). Contra: Washington Mechanies Savings Banl: v. District Title Ins. Co., 65 F.2d $\$ 27$ (D.C. (ir. 1933); Gustin-Bacon Mlfg. Co. v. First Nat. Bank of Englewood, 306 Ill. 179, 137 N.E. 793 (1922) ; Life Ins. Co. of Virginia v. Edisto Nat. Bank of Orangeburg, 166 S.C. 505,165 S.E. 173 (1932). See discussion in Corker, Risk of Loss from Forged Indorsiment, 4 ST.13. L. Rev. 24 (1951). Even where thi drawer can sue the taker, however, the taker may bit protected if it can raise as a defense the delay of the drawer in discovering the forgery or alteration. Sce cases cited under "but cf." signal in note 67 supra, and cases pruhibiting rccovery in nute 71 sufra.

179. In some jurisdictions the taker did not sustain the loss under prior law because the drawee could not recover money paid out on an altered instrument. See nute 32 suspre. In these jurisdictions transierability and risk distribution were better served by placing the loss on the drawee bank, and the Act's shifting of the luss to the drawer is undesirable.

180. See discussion and cases cited notes 16,17 supra.

181. See discussion note 132 sutra.

182. Cases in which statute cuts off all or part of recuvery include Greenstoro Ice \& Fuel Co. v. Security Nat. Bank, 210 N.C. 2H, 186 S.E. 362 (1936) (even if no negligence in employing embezzler who forges checks) and those cited note 40 sufra.

183. The statute might reverse the result of a case such as Denbigh v. First Nat. Bank, 102 Wash. 546, $174 \mathrm{Pac}$. 45 (1918) (drawer not negligent in not discovering forgery made by employee who had been hired only on good recommendations). 


\section{The Uniform Commercial Code $\mathbf{1 8 4}^{\mathbf{8}}$}

The Uniform Commercial Code promulgated in part as a successor to the Negotiable Instruments Law proposes changes in the allocation of losses resulting from forgeries. ${ }^{185}$ Initially, the Code evidences an intent to retain a structure of allocation according to types of forgery, although changes are introduced that modify some existing rules relating to types of forgery. However, the Code contains a host of new negligence concepts which substantially vary the potential loss bearer. Additionally, the Code modifies its basic allocation structure by continuing and adding to the peculiar availability of defenses. These changes, coupled with possibilities for widely varying interpretations due to drafting ambiguities in the Code, ${ }^{186}$ radically alter both current law and a structure of allocating related to type of forgery.

Allocation According to Type of Forgery. The Code, in its comments, explicitly states an intent to retain the forged check rule which places loss on a drawee who has paid or accepted a forged check ${ }^{187}$ when the payment is to a party who has followed reasonable business conduct in obtaining the check ${ }^{188}$

184. For complete Cross Reference Table to Discussion of Cone Sections sec Appendix C, page 477 infra.

185. The Uniform Commercial Code represents an attempt to "simplify and modernize and develop greater precision and certainty in the rules of law governing commercial transactions [and] to preserve flexibility ... and ... continued expansion of commercial practices and mechanisms through custom, usage and agreement of the partics." U.C.C. $\S 1-102(2)$.

186. The Code contains a plea for liberal construction "to promote its underlying purpose and policies." U.C.C. § 1-102(1). However the policies themselves are general enough to allow great latitude of opinion. See note 185 supra. Detailed rules for interpretation include: "(a) Definitions and formal requirements ... are not subject to variation by agreement; (b) Except as otherwise provided by this Act the rights and duties of a third party may not be adversely varied by an agreement to which he is not a party or by which he is not otherwise bound; (c) The general obligations prescribed by this Act such as good faith ... and reasonable care may not be disclaimed by agreement but the parties may by agreement determine the standards by which the performance of such obligations is to be measured if such standards are not manifestly unreasonable; ... (f) The Comments of the National Conference of Commissioners on Uniform State Laws and the American Law Institute may be consulted in the construction and application of this Act but if text and comment conflict, text controls; (g) Prior drafts of text and comments may not be used to ascertain legislative intent." U.C.C. § 1-102(3). Sce Franklin, On the Legal Methods of the U.C.C., 16 LAw \& ConteMr. Prob. 330, 333-5 (1951).

187. "Except for recovery of bank payments as provided in the Article on Bank Deposits and Collections [Article 4] and except for liability for breach of warranty on presentment under the preceding section, payment or acceptance of any instrument is final in favor of a holder in due course." U.C.C. $\$ 3-418$. The actions on breach of warranty include recovery on an altered check or check with forged endorsement. U.C.C. § 3-417. The Comments specify, "This section follows the rule of Price v. Neal . . . under which a drawee who accepts or pays an instrument on which the signature of the drawer is forged is bound on his acceptance and cannot recover back his payment."

188. The protection only extends to a holder in due course. lbid. To be a holder in due course under the U.C.C. a party must not only take the instrument for value, in good 
or who has taken a check previously obtained by some party who was businesslike. ${ }^{189}$ However, the forged check rule is subordinated to other sections in the Code which may operate to abridge or abolish the rule. ${ }^{100}$ In the situations where subordination may produce a result that eliminates the drawee's liability, it will do so by permitting the drawee to recover either from the drawer or from prior parties who handled the checl. Where recovery is against prior parties, these will in turn fall back against those who negotiated the check, and consequently the taker from the forger will ultimately sustain loss. Where recovery is against the drawer, he will sustain ultimate loss only in those jurisdictions where he cannot sue other parties and thus shift the ultimate loss to the taker from the forger.

The extent to which subordination will operate to shift loss from the drawee to the taker rests largely on the way in which courts will construe the Colle. However, at least one change seems clear. Common law generally treated a check which contained both a forged drawer's signature and forged endorsement as a forged check and consequently held the drawee liable. ${ }^{101} \mathrm{By}$ subordinating the forged check rule to the sections on forged endorsements, the Code suggests that such a double forgery will be treated as a forged endorsement. ${ }^{192}$ Consequently, the drawee will be permitted to recover against prior parties and loss will shift to the taker from the forger. ${ }^{103}$ In another set of situations, one commentator suggests that subordination of the forged checl: rule to the warranties sections of the Code may permit the drawee to recover against prior parties on a warranty of "good title to the instrument,"102 al-

faith, and without notice that it is overdue, or has been dishonored, or is subject to defenses, but further must have observed "the reasonable commercial standards of any business in which the holder may be engaged." U.C.C. \$ 3-302(1).

189. "Transfer of an instrument vests in the transferee such rights as the transferor has therein, except that a transferee who has himseli been a party to any fraud or illegality affecting the instrument or who as a prior holder had notice of a defense or claim against it cannot improve his position by taking from a later holder in due course." U.C.C. $\$ 3-201(1)$. Thus a future taker comes under the "shelter" of a prior holder in due course.

190. The forged check rule in $\$ 3-418$ is subordinated to the breach of warranties section (\$ 3-417) and the Article on Bank Deposits and Collections (Article 4). See note 187 sipra.

191. See United States v. Chase Nat Banl, 252 U.S. 495 (1920); Franlini v. Banl: of America Nat. Trust \& Saving Ass'n, 31 Cal. Ap1. 2d 6to, \&\$ P.24 790 (1938); Cairo Bank Co. v. West, 187 Ga. 666, 2 S.E.2d 91 (1939); Herbel v. People's State Banls of Ellinwood, $170 \mathrm{Kan} .620,22 \mathrm{~S}$ P.2d 929 (1951) ; State Bank v. Cumberland Savings \& Trust Co., 168 N.C. 605, 85 S.E. 5 (1915). Contra: McCall v. Corning, 3 La. Ann. 409 (1843); Farmers Nat. Bank v. Farmers \& Traders Bank, 159 Ky. 141, 160 S.W. 980 (1914).

192. Since there is in addition to the forged signature of the maker a forged endorsement, a prior party has breached the varranty "that he has good title to the instrument." $\S \S 3-417$ (1) (a), 4-207(1) (a).

193. This result is not inevitable. Courts may regard the subordination device in the U.C.C. as an inadequate legislative expression of intent to change the common law. See note 227 infra.

194. Beutel, Comparison of the Proposed Commercial Code, 30 NE. L. Rev. 531, 554-5 (1951). 
though this interpretation seems unjustified. ${ }^{10 \pi}$ It may also be argued that the drawee can recover from prior parties by subrogation to the drawer's rights against the holder of a check. ${ }^{106}$ This theory would contend that the purported drawer had a right to recover from a holder who received money on a forged check, ${ }^{107}$ and that the drawee must be subrogated to this right to prevent his loss from payment of the check. However, this interpretation also seems unlikely. ${ }^{108}$ Finally, since the forged check rule is subordinated to sections authorizing and effectuating informal agreements between banks, ${ }^{100}$ abnegation of the rule could result from agreements between banks always to refund payment received for forged checks. ${ }^{200}$ The collecting bank, having patid

195. The comments to the section suggest that this interpretation was not intended by the drafters. U.C.C. $\$ 3-418$, Comment 1 ; see note 187 supra. Furthermore a warranty denied to the drawee, but given to transferees and subsequent holders in good faith, is that "all signatures are genuine." U.C.C. $\$ \$ 3-417$ (2) (a), 4-207(2) (a). The omission of this warranty for the protection of the drawee supports the conclusion that the intention of the Code was not to give the drawee the right to recover for a forged check on the warranties accompanying presentment for payment. Finally, existing law would refute an interpretation based on the premise that parties cannot have good title to a forged check. Bank of England v. Vagliano Bros., [1891] A.C. 107; Trust Co. of America v. Hamilton Bank, 127 App. Div. 515, 112 N.Y. Supp. 84 (1st Dep't 1908). 'The party las good title to the paper, only the paper is just not enforcible against the purported drawee or maker since he did not draw it. Edgington v. Security-First Nat. Bank of Los Angeles, 78 Cal. App.2d 849, 179 P.2d 640 (1947); Cowan v. Thompson, 25 Temn. App. 130, 152 S.W.2d 1036 (1941).

196. "If a payor bank has paid an item over the stop payment order of the drawer or maker or otherwise under circumstances giving a basis for objection by the dratucr or waker, to prevent unjust enrichment and only to the extent necessary to prevent loss to the batuk by reason of its payment of the item, the payor bank shall be subrogated to the rights (a) of any holder in due course on the item against the drawer or maker; and (b) of the payee or any other holder of the item against the drawer or maker whether on the item or under the transaction out of which the item arose; and (c) of the drawer or maker against the payee or any other holder of the item with respect to the transaction out of which the item arose." U.C.C. \$ 4-407 (emphasis added).

197. Such right exists in some jurisdictions. See cases cited notes 71,178 supra.

198. The intent of the section is to bar recovery by the drawee-see note 195 supra. And the section, by its wording, may be limited to stop payment orders and/or unjust enrichment.

199. The forged check rule is subordinated to Article 4 which includes the right of agreement. See note 187 supra.

200. "The effect of the provisions of this Article [4] way be varied by agrecment except that no agreement can disclaim a bank's responsibility or linit the measure of damages for its own lack of good faith or failure to exercise ordintry care." U.C.C. $\S 4-103(1)$.

"Notwithstanding the provisions of Section 1-102 (3) (b), Federal Reserve regulations and operating letters, clearing house rules, and the like, have the effect of agreements under subsection (1), whether or not specifically assented ta by all parties interested in items handled." U.C.C. § 4-103(2) (emphasis added). See § 1-102(3)(b), note 186 supra. Thus, they bind "en masse . . . virtually every adult person and business organization in the United States ... on the principle that collecting banks acting as agents have authority to make binding agreements with respect to items being handled." U.C.C. \$4-103, Comment 3. 
the drawee pursuant to agreement, would initiate the chain of suits against prior parties until the taker from the forger is reached." However, the efficacy of such agreements may be restricted. They may be defeated by a declaration of unconstitutionality, ${ }^{202}$ and by argument that banlss cannot adversely affect the rights and duties of third parties ${ }^{\text {sis }}$ or disclaim responsibility for failure to exercise ordinary care. ${ }^{2 n}$ Further, unless the agreements are made in Federal Reserve Regulations and operating letters or clearing house rules. ${ }^{205}$ the agreements may not be binding on depositors under the Code. ${ }^{208}$ Thus generally, the forged check rule probably remains intact.

The Code purportedly treats forged endorsements as does existing law.:07

201. Recovery would be based on the warranty that all signatures were genuine. U.C.C. $\$ \$ 3-417$ (2) (a), 4-207(2) (a). See note $20 \$$ infra.

202. See Gilmore, Uniform Commercial Cnde: A Reply. 61 YaLe L.J. 364, 375-6 (1952).

203. Under U.C.C. $\$ 1-102(3)$ (b) a party cannot be bound by an agreement to which he has not assented or in which he has no interest. See note 186 supra. Thus, it may be argued that even if the collecting bank were to agree to allow recovery by the drawee bank, the collecting bank could not fall back on the party who delivered the ched: for collection. But this objection would probably fail because third parties' rights an be affected if the act so provides. Ibid. And the act specifies that parties with an interest, i.e., the depositors for collection are bound even if they do not specifieally assent to the agreement. See U.C.C. $\$+103$, Comments 2,3 ; and note 200 sapra.

204. U.C.C. $\$ 4-103(1)$; and text at note 200 supra. As this contention would probably require a showing in each separate case that the bank failed in its duty on the specifically questioned check, the burden of proof would be exceedingly difficult to sustain. Furthermore, "ordinary care" is what banks usually use, and if all banks operate under the agreement, this argument would probably fail. The Code provides: "Action or non-action approved by this Article or pursuant to Federal Reserve regulations or operating letters constitutes the exercise of ordinary care and, in the absence of special instructions, action or non-action consistent with clearing house rules and the like or wihh a gercrol banking usage not disapproced by this Article, prima facie constitutes the exercise of ordinary care." U.C.C. $\$$ 4-103(3) (emphasis supplied).

205. If the agreement is made in Federal Reserve regulations and operating letters or clearing house rules, any party depositing a check for collection would be bound by the agreement. U.C.C. $\$ 4-103(2)$, note 200 supra.

206. The contention would first require a holding that an agreement among banls pursuant to U.C.C. $\$ 4-103$ (1), would not by itself bind the parties sending the check through the collection system. See note 203 supra. Then the court would have to find that the agreement was not like a Federal Reserve regulation, operating letter, or clearing house rule. See U.C.C. $\$ 4-103(2)$, note 200 supra. The conments indicate that an agreement among "a number of banks or even all the banks in an area simply because they are banks would not itself by virtue of the phrase 'and the like," meet the purposes and objectives of ..." agreements with ability to bind every participant in the banling process without regard to the limitations on agreements in the Cade. See note 200 sispro. Another argument against the effect of the agreements, even if made through the Federal Reserve System, is that the instrument and all actions on it have been discharged under U.C.C. $\$ 3-601$ (3) when read in conjunction with U.C.C. $\$ 3-418$.

207. The Code "retains the generally accepted rule that the party who accepts or pays does not 'admit' the genuineness of indorsements, and may recover from the person presenting the instrument when they turn out to be forged." U.C.C. $\$ 3-417$, Comment 3 . 
By providing that every transferee warrants that "signatures are genuine" and the presenter for payment warrants that "he has good title to the instrument," the Code permits every party including the drawee to fall back on prior parties when a forged endorsement occurs. ${ }^{208}$ Thus the taker from the forger is left only with his right against the forger. However, the Code does provide possibilities for modification of the forged endorsement rule. Parties have a right to stipulate out these warranties established by the Code, and consequently a taker from the forger who so stipulates in transferring the check may avoid liability. ${ }^{209}$ But this possibility of stipulation out of warranties is not available to a person who presents a check to a bank for collection or payment. 210

The U.C.C. substantially follows the existing law of altered instruments..$^{211}$ Since the presenter for payment and all transferees warrant that "the instri-

208. U.C.C. \& 3-417: "Warranties on Presentment and Transfer.

"(1) Unless otherwise agreed any person who obtains payment or acceptance and any prior transferor warrants to a party who pays or accepts in good faith

(a) that he has a good title to the instrument or is authorized to obtain payment or acceptance on behalf of one who has a good title; and ...

(c) that the instrument has not been materially altered, and that he has no knowledge that the signature of the maker or drawer is unauthorized, except that such warrantics arc not given by a holder in due course who has taken a draft drawn on and accepted by a bank: after such alteration or signature or by a holder in due course of a note. This exception applies even though a draft has been accepted 'payable as originally drawn' or in equivalent terms.

"(2) Unless otherwise agreed any party who transfers an instrument for consideration warrants to his transferee and if the transfer is by indorsement to any subsecutent holder who takes the instrument in good faith that

(a) all signatures are genuine or authorized; and

(b) the instrument has not been materially altered; and

(c) the transfer is rightful; and

(d) no defense of any party is good against him; and

(e) he has no knowledge of any insolvency proceeding instituted with respect to the maker or acceptor or the drawer of an unaccepted instrument."

209. Such stipulation is possible under U.C.C. $\S 3-417$, which specifies that warrantics apply "unless otherwise agreed."

210. The ability to aiter by agreement the warranties given to banks is omitted from the bank collection warranty section, U.C.C. $\$ 4-207$, which is otherwise comparable to U.C.C. \& $3-417$, the general warranty section. This statutory protection was particularly unnecessary since banks could have given themselves the same protection by refusing to agree to such restrictive warranties.

211. Existing law is discussed at page 424 supra. U.C.C. $\$ 3-407$ reads:

"Alteration.

"(1) Any alteration of an instrument is material which changes the contract of any party thereto in any respect.

"(2) As against any person other than a subsequent holder in due course

(a) alteration by the holder which is both fraudulent and material discharges any party whose contract is thereby changed unless that party assents or is precluded from asserting the defense;

(b) no other alteration discharges any party and the instrument may be enforced 
ment has not been materially altered," in the absence of negligence all parties can fall back until the taker from the forger bears the loss.212 This is consistent with one line of decisions in existing law, but rejects the rule of some jurisdictions placing loss on the drawee for the full amount of a checl, where the payee's name is altered and for the raised amount when the amount is changed. ${ }^{213}$ In the absence of negligence, as under existing law, the original tenor of the altered instrument may be charged to the drawer by the drawee bank $^{214}$ or enforced against the drawer by a former holder. ${ }^{215}$

To the extent that it preserves existing rules based on allocation by type of forgery, the Code is subject to the same objections as existing law for its failure to serve goals involving transferability, risk distribution, negligence, and uniform treatment of parties. ${ }^{210}$ Indeed, the comments to the Code, in straining to offer justification for its structure, present contradictory rationales. Admitting the fictional nature of the argument that the drawee can verify the signature of the drawer, the comments to the forged check rule affirm that the loss should be placed on the drawee to "end the transaction on an instrument when it is paid rather than reopen and upset a series of commercial transactions at a later date when the forgery is discovered." 117 At the same time, the comments on the section embodying the forged endorsement and altered instrument rules, which allow the drawee to recover, state the converse: "drawee is in a position to verify the drazier's signature by comparison with one in his hands, but has ordinarily no opportunity to verify an endorse-

according to its original tenor, or as to incomplete instruments according to the authority given.

"(3) A subsequent holder in due course may in all cases enforce the instrument according to its original tenor, and when an incomplete instrument has bsen completed, he may enforce it as completed."

Since a person only becomes a holder in due cuurse by following reasonable business conduct or taking from a person who was a holder in due course-see notes $188-9$ sufruonly these persons may enforce the instrument according to its original tenor.

212. U.C.C. $\$ \$ 3-417,4-207$. Sce note 208 sipra.

213. There is a split in existing cases with the majority allowing a drawee to recover funds paid on an altered instrument. See notes 32,35 surra. The U.C.C. resolves this conflict in favor of the majority view. \$ 3-417.

214. "A bank which in good faith makes payment to a holder may charge the indieated account of its customer according to (a) the original tenor of his altered item." U.C.C. $\S 4-401$.

215. U.C.C. $\S 3-407(3)$, note 211 supra.

216. Uniformity of doctrine between states would of course be obtained by general enactment of the U.C.C. However parties who act similarly in analogous situations are still treated differently. See discussion pages $4 \$ 0,443-4$ supra. On criticism relating to other objectives, see pages 440-7 supra.

217. U.C.C. $\$ 3-418$, Comment 1. 
ment."218 Nor can it be supposed that reopening the transactions on a check with a forged endorsement is any less unsettling than similar action on $a$ forged check;219 yet the draftsmen do not think that objective significant enough to consider in the forged endorsement and alteration comments. The contradiction, of course, suggests the inability of the codifiers to justify different rules for different types of forgery.

Where the Code may introduce modifications of the existing forged check rule its results are even less desirable than existing law. All four possible modifications to the forged check rule-recovery on double forgery checks, recovery under breach of warranty, subrogation, and agreements to refundshift loss away from the drawee bank without any basis in negligence, and in fact may permit even a negligent drawee to shift its loss to others. ${ }^{220}$ These restrictions on the drawee bank's liability for forged checks also defent the goal of promoting most effective risk distribution, and, by shifting the loss to prior transferees, impair transferability. The possibility of an agreement to refund made by banks is particularly objectionable as a means of attempting intelligent and equitable loss allocation since it permits banks in their own self-interest to determine the liability of others. ${ }^{221}$

The change in the forged endorsement rule-stipulation out of warrantics -fails to advance substantially existing law. Only transferability is furthered by this change which shifts the loss away from the taker from the forger. ${ }^{222}$ But since the change fails to shift the loss to the drawee bank, the best risk distribution is not obtained. Moreover, the change has no basis in negligence. Stipulation may permit a negligent party to shift the loss to another, but the other party may protect himself by refusing to agree to the restriction of the

218. U.C.C. § 3-417, Comment 3.

219. Under the forged endorsement rule the time in which an action may be brought is extensive. See, e.g., Teas v. Third Nat. Bank \& Trust Co., 125 N.J. Eq. 224, 4 A.2d 64 (Ct. Err. \& App. 1939) (payee's suit in conversion against collecting bank allowed after 7 years) ; Henderson v. Lincoln Rochester Trust Co., 303 N.Y. 27, 100 N.E.2d 117 (1951) (payee suing collecting bank under contract theory has up to 6 years).

220. The subrogation section has no requirement that the bank be free from negligence before it may take advantage of its provisions. In fact when a bank does pay over a stop order, it has usually been careless; yet the section clearly is meant to apply herc. U.C.C. $\S 4-407$, note 196 supra. There is no requirement of freedom from negligence in dis: covering forgeries or alterations before the bank may take advantage of the warrantics. U.C.C. $\S \$ 3-417,4-207$; see note 208 supra. Once having discovered the forgery, however, the bank must act in a reasonable time or is barred from recovering the extent of the loss caused by the delay in making claim. U.C.C. $\$ 4-207$ (4); see note 239 infra. Negligence requirements for agreements are discussed in note 204 sipra.

221. The "agreement" sections of the Code have been criticized by the Code's staunchest defenders. See, e.g., Gilmore, Uniform Commercial Code: A Reply, 61 YALE L.J. 364, 375 (1952).

222. See discussion pages 434-5 supra. Transferability may be undermincel if the warranties are interpreted to eliminate the defense of material change of position. See Note, Warrantics to a Payor or Acceptor under the U.C.C. \$ 3-417(1), 27 IND. L.J. 561,569 (1952). 
warranty. While it is true that ability to stipulate out of warranties does provide a flexible arrangement enabling parties to model their liability to the type of commercial transaction in which they are involved, in practice this may mean only that a party with superior bargaining power can secure a restriction of his liability. Here, as another indication of the favored treatment afforded banks by the forgery sections of the Code, the edge in bargaining power cannot be exercised by one who presents a check to a bank for collection or payment.223

The U.C.C. adopts the less desirable of the two existing views regarding altered instruments. By adopting the view that drawees can fall back on prior parties, the Code defeats most effective risk distribution and transferability: And while the Code may operate to place the loss on a taker who was in fact negligent, it also places the loss on non-negligent takers. In contrast, the rejected line of cases placing loss on the drawee insulates both negligent and non-negligent takers, but promotes transferability and most effective risl: distribution.

Allocation Modified by Negligence Concepts. The Uniform Commercial Code superimposes negligence concepts on its basic allocation structure. W"hile these concepts encompass many of the negligence doctrines prevalent in existing law, the Code also introduces several changes. Two of these changesi.e., rules relating to negligence of drawers and payees in contributing to forgery and negligence of a drawer in failing to report a forgery-modify allocation regardless of the type of forgery involved. Other changes made by the Code apply specifically to forged instruments or forged endorsements.

The Code provides that drawers and payees whose negligence "substantially contributes" to a material alteration or forgery cannot assert the alteration or forgery against a party who took an instrument for value, in good faith. and in observance of reasonable standards of his business. 201 This provision can be invoked, for example, to place the loss on a drawer who created an instrument which could be easily altered, who mismailed a check which then had a forged endorsement placed upon it, or who has notice that his name has been forged and fails to prevent subsequent forgeries by the same person. Additionally, the doctrine may place liability on a payee where his similar

223. Warranties given banks cannot be varied by agreement. U.C.C. $\$ 4-207$. Sce note 210 sipra.

224. "Any person who by his negligence substantially contributes to a material alteration of the instrument or to the making of an unauthorized signature is precluded from asserting the alteration or lack of authority against 3 holder in due course or against a drawee or other payor who pays the instrument in good faith and in accordance with the reasonable commercial standards of the drawee's or payor's business." U.C.C. $\$ 3-406$.

225. The existing case law on this subject is in conflict. See cases on carcless creation in notes 64 and 65 supra; cases on negligent mailing in note 152 supra; cases on insdequate supervision in notes 58 and 59 supra. 
conduct facilitates the forging of his endorsement.220 While the specific examples suggested may now provide grounds for liability in some jurisdictions, the Code introduces change in so far as it carries all of these existing negligence concepts to all jurisdictions. However, the full impact of the generalized negligence doctrine is partly contingent upon interpretations courts will give to such terms as "substantially contributes." Some courts may read into these terms already existing doctrine and its limitations and hence nutlify any new impact of the Code. ${ }^{227}$ Thus, for example, some courts may still find that the intervening criminal act of forgery precludes a determination that the negligence of a drawer who mismailed a check substantially contributed to a forged endorsement.228 However, few courts are likely to limit the Code in this manner. ${ }^{229}$ Courts may also limit the negligence doctrine by holding "shelter" provisions applicable. In some circumstances under these provisions a party who negligently takes a check is given the same protection as if he had exercised care, providing some prior party did exercise care. ${ }^{230}$ A collecting bank, for example, which takes an instrument proper business practice would have demanded it to refuse, may effectively resist recovery from a negligent drawer or payee if any party prior to the bank took the check for value and in good faith and exercised care in handling the instrument. ${ }^{231}$ In any event, the general negligence doctrine of the Code does carry with it a concept, analogous to contributory negligence, that is to some extent novel. Parties are prevented from shifting loss to a negligent drawer or payee if the parties have themselves obtained the check without exercising reasonable care. $^{232}$

226. This is in accord with the preferred view. See cases cited notes 62, 63 supra.

227. The practice of strictly construing statutes in derogation of the common law is familiar. See e.g., Colonial Trust Co. v. National Bank, 50 Pa. Super. 510 (1912).

228. See Fitzgibbons Boiler Co. v. Nat. City Bank, 287 N.Y. 326, 39 N.E.2d 897 (1942); Glasscock v. First Nat. Bank of San Angelo, 114 Tex. 207, 266 S.W. 393 (1924). Contra: Provident Savings Bank \& Trust Co. v. Western \& Southern Life Ins. Co., 41 Ohio App. 261, 179 N.E. 815 (1931). See cases cited notes 57 and 59 supra.

229. Such an interpretation is contrary to the comments: "[The section] rejects decisions which have held that the maker of a note owes no duty of care to holder because at the time the instrument is drawn there is no contract between them." U.C.C. $\$ 3-406$, Comment 2. It also contravenes the policy behind the section that a person who is careless in creating or delivering an instrument is creating a hazard to all parties who may come in contact with the check and so is justifiably responsible for any loss which occurs.

230. See note 189 supra.

231. This result is contrary to the comnents, one of which states: "Thus any bank which takes or pays an altered instrument which ordinary banking standards would require it to refuse cannot take advantage of the estoppel." U.C.C. $\$ 3-406$, Comment 6. But the result seems inevitable due to the clear intent of the text since, in case of conflict between text and comments, the text controls. See U.C.C. $\$ 1-102(3)(f)$, note 186 supra.

232. This is accomplished since only a holder in due course gets the protection, and a holder only becomes a holder in due course by exercise of proper business methods. U.C.C. § 3-302(1). See note 188 supra. 
The Code also embodies a negligence doctrine which imposes on the drawer. in all types of forgery cases, a duty to discover and notify the drawee bank, within specified time limits, of alterations and forgeries. ${ }^{233}$ Within these time limits a drawer may still be held liable if he fails to exercise "reasonable care to examine the statement and items" in order to discover forgery and promptly notify the bank after discovery. In most cases a drawer who fails to discover and notify within ninety days is precluded from having his account recredited for any forgeries or alterations repeated by the same person. In occasional cases where illness, absence from the country or other similar cause prevents the drawer from examining his statement, he has up to a year to discover and report. And in the case of a forged endorsement the draver has three years before he is precluded from asserting the forgery against the bank. To gain protection of these time limits the bank must exercise only good faith. However, all of the time limits may be modified by the Code's "informal agreements" section; banks may uniformly agree to impose on their depositors a period, within which notice must be given, ${ }^{231}$ that may run as short as ten days or two weeks. ${ }^{235}$

233. U.C.C. $\$ 4-406$ reads: "Customer's Duty to Discozer and Refort Unauthorized Signature or Alteration.

"(1) Where a bank sends to its customer a statement of account accompanied by iterns paid in good faith....

(a) the customer must excrcise reasonable care to examine the statement and items to discover his unauthorized signature or any alteration and must notify the banl: promptly after discovery thereof; he is liable to the bank for any loss suffered by it which results from his failure to do so; and

(b) except as provided in subsection (2) a customer who does not vithin ninety days discover and report his unauthorized signature or any material alterstion on the fase of any such item is precluded from asserting against the bank both such unauthorized signzture or alteration by the same person on items paid in good faith by the banls subzequent to the sending of the first item or notice to the customer of any such signature or alteration; and

(c) without regard to subsection (2) a customer who does not within one year discover and report his unauthorized signature or any alteration on the face or bacls of the item or within three years any unauthorized indorsement, is precluded from asserting against the bank such unauthorized signature or indorsement or such alteration.

“(2) Except as provided in subsection (1)(c) a customer who has not for good cause examined such statement and items may within thirty days after such cause cences to operate demand recredit or repayment for the amounts paid on items materially aitcred or bearing his unauthorized signature." (Emphasis supplied.)

234. On the ability of banks to bind depusitors by agreements see notes $200,203-6$ sifra.

235. Miany banks include in their depositor's contract or statement of account returned with cancelled checks a provision that the account will be considered settled if no notice is received within ten days or two weeks. The Code apparently intends to supersede current laws in which these agreements between banks and their depositors have with great frequency been given short shrift. See, c.g., Worthen Banls \& Trust Co. v. Kelly-Nelson Construction Co., - Ark. -, 245 S.W.2d 405 (1952) (agreement to rejort in 10 days on monthly statement of account not endorsed); Frankini v. Bank of Ameriea Nat. Trust \& Savings Ass'n, 31 Cal. App.2d 666, S\& P.2d 790 (1939) (signed agreement for 10 dzys 
While most jurisdictions today, through one device or another, impose similar duties on the drawer, 236 the Code establishes uniform time periods, presumably unifies the grounds for liability, and permits a modification of the time limits by its "informal agreement" authorization. Again, however, the full impact of the Code is not ascertainable without judicial interpretation, for common-law rules may reaclily be read into the Code provisions. In situtations where a drawer-employer has delegated the duty of examining checks to an employee who participates in the forgery, for example, will the employer's duty of "reasonable care" be discharged by initially prudent conduct in selecting the employee and delegating duty, ${ }^{237}$ or will the employer nevertheless be held liable ?238 If the delegation is held not to relieve the drawer, the Code is ambiguous in indicating whether his failure to discover and report bars him after ninety days, or whether the delegation of authority constitutes an excuse for not personally examining the statement which will thus allow the drawer a full year before he is precluded from having his account recredited.

The Code also adopts some negligence standards relating to the conduct of the drawee. As under existing law, a drawee bank which has learned of a forgery must promptly notify other parties. ${ }^{230}$ Failure so to notify will shift the loss occasioned by the delay to the drawee when it may have had grounds for recovery against others. ${ }^{240}$ However, the Code has not included the rules

notification not enforced because bank did not call it to depositor's attention and it is an unreasonable advantage achieved by imposition) ; First Nat. Bank of Atlanta v. American Surety Co., 71 Ga. App. 112, 30 S.E.2d 402 (1944) (10 day notification agreement on returned voucher not enforced even though depositor signed receipt with voucher); Denbigh v. First Nat. Bank, 102 Wash. 546, 174 Pac. 475 (1918) (agreement to limit time strictly construed because of existence of statute cutting off actions after 60 days). Contra: Brunswick Corp. v. Northwestern Nat. Bank \& Trust Co., 214 Mint1، 370, 8 N.W 2d 333 (1943) (10 day agreement enforced against employer in embezzlement scheme even though there was a state six month statute of limitations and the drawee bank was negligent); McCormick v. Rapid City Nat. Bank, 67 S.D. 586, 297 N.W. 39 (1941) (15 day agreement upheld where it was part of signed contract).

236. See notes 39-43a, 55, 56, 176 supra.

237. Merchants' Nat. Bank v. Nichols \& Shepard Co., 223 Ill. 41, 79 N.E. 38 (1906); Kenneth Investment Co. v. National Bank, 103 Mo. App. 613, 77 S.W. 1002 (1903). See cases cited note 148 supra.

238. See General Cigar Co. v. First Nat. Bank, 290 Fed. 143 (9th Cir. 1923); First Nat. Bank v. Richmond Electric Co., 106 Va. 347, 56 S.E. 152 (1907). See also cases cited notes $125,149,150$.

239. U.C.C. § 4-207(4) : "Unless a claim for breach of warranty under this section is made within a reasonable time after the person claiming learns of the breach, the person liable is discharged to the extent of any loss caused by the delay in making claim." For the scope of the breach of warranty involved see note 208 supro.

240. Cases under existing law reaching the same result include: Guaranty Bond State Bank of Athens v. Fraternal Bank \& Trust Co., 68 S.W.2d 305 (Tex. Civ. App. 1934) (recovery reduced by loss caused when delay enabled forger to withdraw funds from defendant collecting bank) ; cf. Pennsylvania Mutual Life Ins. Co. v. Real Estate-Land 'Title \& Trust Co., 116 Pa. Super. 81, 176 Atl. 747 (1935) (drawee not barred by 16 day deday where no harm sustained). 
that hold the drawee liable when it has been negligent in other ways, such as failing to discover a forged drawer's signature. $2 x$

In addition to negligence concepts applicable regardless of the type of forgery, the Code also introduces modifications of current negligence exception: to the forged check, forged endorsement and altered instrument rules.

In forged check cases the U.C.C. adopts the rule existing in many jurisdictions that drawee bank may recover money paid on a forged check and resist payment of an accepted forged check when dealing with a party who failed to meet commercial standards applicable to his business when he took the check. ${ }^{242}$ Then, since each party may fall back on his transferee, the loss is finally shifted to the taker from the forger..$^{243}$ This Code provision is narrower than one existing view which holds that recovery can always be obtained unless the prior party has changed his position in reliance on payment. ${ }^{24}$ And the provision additionally excludes operation of any other negligence theory* for recovery. However, it broadens the drawee's right to reimhursement in jurisdictions that recognized no negligence exception. ${ }^{245}$

In forged endorsement cases. the Code places loss on the drawer in the same situations as the Fictitious Payee . Ict discussed above, ${ }^{280}$ although its rationale differs from that of the Act..47 The Code also broadens the "impostor" exception to the forged endorsement rule, thus enlarging responsibility of the drawer to the benefit of the taker from the forger. The justification for holding the drawer liable for delivering to an impostor is changed from the previous rationale that the drawer "intended" to pay the impostor,"2s to the statement that regardless of drawer's intent, the endorsement of an

241. See note 220 supra. Compare existing law at notes 44,158 sisra.

242. U.C.C. $\$ 3-418$, note 193 supra. See notes $1 \$ \$$ and $1 \$ 9$ supra for requirement of good business practice.

243. U.C.C. $\$ 3-417(2)(a)$, note 208 suira.

244. Union Nat. Bank v. Farmers' \& Mechanics' Nat. Bank, 271 Pa. 107, 114 Atl. 505 (1921) ; National Loan \& Exchange Eank of Colunbia y. Lachovitz, 131 S.C. 430, 128 S.E. 10 (1925); Aetna Casualty \& Surety Co. v. Corpus Christi Nat. Banls, 186 S.W.2d S40 (Tex. Civ. App. 1944).

245. See cases cited note 143 supra.

246. See text at notes $167-75$ supra. U.C.C. \$ 3-405 reads: "Impostors; Signature in Name of Payee.

“(1) An indorsement by any person in the name of a named payee is effective if

(a) an impostor by the use of the mails ur otherwise has induced the maker or drawer to issue the instrument to him or his confederate in the name of the payee; or

(b) a person signing as or on behalf of a drawer intends the payee to have no interest in the instrument; or

(c) an agent or employee of the drawer has supplied him with the name of the payce intending the latter to have no such interest.

"(2) Nothing in this section shall affect the criminal or civil liability of the person so indorsing."

247. The Fictitious Payee Act makes the check payable to bearer-see note 167 sipra -while the U.C.C. makes the indorsement of the forger effective. See note 246 suspr.

248. See cases cited note 49 supra. 
impostor is effective. ${ }^{249}$ Doctrinally, this explains the Code's extension of the drawer's liability to the previously uncovered situations in which the imposture was made through the mail or where delivery was to a confederate of the party forging an endorsement. ${ }^{250}$

For altered checks, the U.C.C. introduces the rule that, aside from the drawee bank, ${ }^{251}$ only a party who has obtained an instrument in accordance with the reasonable standards of his business or who has obtained an instrument from one who has exercised similar care can enforce the original tenor of the check. ${ }^{262}$ Under existing law only good faith was necessary to enforce the original tenor against the drawer. ${ }^{253}$ To the extent that this will reduce the ability of prior parties to enforce checks, it shifts part of the loss from the drawer to the taker from the forger.

The negligence modifications adopted by the Code represent some improvement over existing law in attaining the goal of placing loss on negligent parties. In so far as the Code introduces new negligence concepts and extends existing rules, the likelihood that a negligent party will sustain loss is, of course, increased. Thus the doctrine of negligence contributing to loss, the duty to discover and report forgeries, and the requirement of reasonable business care in accepting instruments are all steps forward towards ensuring allocation based on negligence. ${ }^{254}$ However, the Code's negligence provisions are far from perfect, and in some instances they directly thwart allocation according to negligence.

Under the automatic termination of drawee bank's liability to the drawer, ${ }^{206}$ the Code places loss on innocent parties even where others are negligent. If courts read the Code to place loss on a drawer who "misplaces" trust, a drawer who exercised prudent business conduct in hiring a dishonest employee and delegating to him the supervision of the checking account may be unable

249. U.C.C. \& 3-405(1) (a), note 246 supra.

250. Existing law frequently did not invoke the impostor rule in these situations. Sce cases cited note 48 supra. However, the U.C.C. does preserve the exception that when an impostor represents himself to be another person's agent and the check is made out to the purported principal, the drawer is protected. U.C.C. \& 3-405, Comment 2. See cases cited note 48 supra.

251. U.C.C. $\$ 4-401$, note 214 supra.

252. The Code provides that only a holder in due course may enforce the original tenor. U.C.C. § 3-407. To become a holder in due course a party must exercise reasonable commercial care. See notes 188, 189 supra.

253. Under existing law a holder in due course could enforce the original tenor. NIL $\S 124$. However, to become a holder in due course a party only had to exercise good faith, not "commercial care." NIL § 52. See Howard Nat. Bank v. Wilson, $96 \mathrm{Vt}$. 438, 120 Atl. 889 (1923).

254. Respectively U.C.C. §§ 3-406, 4-207(4), 4-406(1) (a), 3-302(1) (b).

255. U.C.C. $\$ 4-406$, note 224 supra. 
to recover funds from the drawee.250 And a non-negligent drawer will also bear loss where extenuating circumstances make his failure to report "reasonable" even though the time limit has expired. Here, the Code is particularly objectionable, since even if the drawee has been negligent, the prudent drawer sustains the loss. ${ }^{257}$ Moreover, in a forged endorsement situation, the lnowledge of the forgery may rest exclusively with the payee or his agent. But though it is the payee, not the drawer, who fails to report the forgery, the drawer will be barred from recovering against the drawee. ${ }^{253}$

The exception to the forged check rule, permitting a drawee to shift loss to a negligent party, is too narrow to ensure always placing loss on negligent parties. A person who took from the forger may negotiate his check to another person who sends the check in for collection, or may present the ched: for collection at a bank which allows him to draw on it before the forgery is discovered. Here, the drawee cannot recover from the collecting bank or a careful party who took the check from a negligent taker; nor can it sue the negligent taker directly. ${ }^{253}$ Thus the intervention of innocent parties may operate to protect the taker. ${ }^{\text {an }}$ The Code might easily have remedied this weakness by providing that a party who did not exercise proper business care in taking the instrument warranted to the drawee that all signatures were genuine. This unquestionably would have allowed the drawee to bypass the intervening parties and sue the taker.

The impostor and fictitious payee rules further exemplify the Code's use of concepts which may place loss on prudent people where others are negligent in handling a check. Extension of the impostor rule to cover situations where imposture is by mail or delivery is to a confederate does eliminate a distinction in liability unrelated to conduct.201 Nevertheless, the rule still retains its absolute allocation of loss to the drawer regardless of his conduct and the conduct of others associated with the check. Consequently, the same objections apply as those regarding existing law: a drawer will bear loss not

256. See discussion in text at notes 237-8 stipra.

257. Under Article 4, while the depositor must use reasonable care to diccover the forgery the duty of the drawee bank is only to exercise good faith. See U.C.C. $\$ 4-406$, note 239 supra. Current law in many jurisdictions does not permit a negligent drawer to take advantage of the negligence of other parties. See cases cited notes 4,158 sigra.

258. Currently, in some jurisdictions the drawer will be protected from ultimate loss since the payee's action against him is barred. Then the forged cheels will have operated to discharge the drawer's obligation to the payee and the latter will sustain the burden. Mills v. Hurley Hardware \& Furniture Co, 129 Ark. 350, 196 S.W. 121 (1917) ; MrFadden v. Follrath, 114 Minn. 85, 130 N.W. 542 (1911). See discussion in Corker, Risle of Less From Forged Indorsements, 4 STAN. L. Rev. 24, 32-42 (1951).

259. See notes 47, 70 supra; and U.C.C. $\$ \$ 3-417,4-207$.

260. The innocent parties become holders in due course who are protected under U.C.C. \$ 3-418. A collecting bank becones a holder in due course when it estends credit on an item given for collection on the first in first out rule. U.C.C. $\$ \$ 4-209,4-208(3)$.

261. U.C.C. $\$ 3-405$, note 246 supra. However, the Cude does mut abolish all distinstions in liability in impostor situations. See note 250 sufro. 
only where he is not negligent, ${ }^{262}$ but where others are negligent. ${ }^{203}$ The identical criticism applies to the Code's treatment of the fictitious payee rule. Again the difficulty can be easily remedied. Applying a portion of the Code's general negligence philosophy, one who fails to exercise reasonable commercial care should not be permitted to take advantage of a negligence rule to recover.

The negligence modification of the altered instrument rule allows a drawee, despite its negligence, to enforce the original tenor of an instrument against the drawer. ${ }^{264}$ This may create a double liability for the drawer since he may still be obligated to the payee on the underlying transaction for which the check was initially issued. In these situations, charging the original tenor to the drawer shifts the forgery loss to him. Since the drawee in taking and paying an instrument should exercise only the highest care, it seems palpably unreasonable to allow a drawee who may have negligently taken a check from the forger or paid an obviously altered instrument to recover from a prudent drawer. There appears to be no reason why the drawee is not required, as are other parties who attempt to enforce the original tenor of the instrument, to have exercised reasonable commercial care. ${ }^{265}$

Since, with the single exception of the rule requiring the drawee to give prompt notice of discovered forgeries, the Code's negligence modifications place loss on parties other than the drawee, most effective risk distribution is impeded. Generally, this result can be justified if the objective of allocating loss according to negligence is deemed paramount. However, as pointed out above, in many situations, the Code's "negligence" provisions in fact place loss on careful parties. Here, the priority of a negligence objective is patently inapplicable as justification for shifting loss away from the drawee. Thus, for example, preventing recovery from the drawee by a prudent clrawer due to the statute of limitations ${ }^{206}$ or permitting a negligent drawee to charge a drawer for the original tenor of an instrument, ${ }^{267}$ not only defeat negligence objectives, but frustrate effective risk distribution without cause. Moreover, where both the drawee and other parties are negligent, the Code frequently shifts loss to the others, as, for example, where both drawer and drawee are negligent in discovering a forged or altered check, ${ }^{208}$ or where a negligent

262. See cases cited note 139 supra.

263. See case cited note 140 supra, and discussion note 50 supra.

264. All the drawee must exercise is good faith. U.C.C. $\$ 4-401$, note 214 supra.

265. Courts may avoid this result since U.C.C. $\$ \$ 3-407$ and $4-401$ are contradictory. The former specifies that "As against any person other than a subsequent holder in due course (a) alteration . . . discharges any party whose contract is thereby changed," (Emphasis supplied.) Since the drawee is not a holder in due course, a court could resolve the conflict denying effect to $\$ 4-401$ unless the bank exercised reasonable business care or took from a holder in due course. Contrast U.C.C. \$ 3-406 in which the drawee bank must exercise due care before it may debit a negligent drawer's account on an alteration or forgery. See note 224 supra.

266. See U.C.C. \$ 4-406, note 233 supra; and discussion at notes $257-8$ supra.

267. U.C.C. § 4-401, note 214 supra; and discussion at note 264 supra.

268. U.C.C. \& 4-406, note 233 snipra. 
drawee may recover from a negligent prior party on a forged chech. ${ }^{260}$ Again. risk distribution is thwarted without justification.

Transferability is furthered by the Code's doctrines which place the loss on negligent drawers and payees, though to some extent reluctance initially to use checks may result. ${ }^{270}$ But even where transferability is theoretically stymied by making a negligent taker bear the loss due to his carelessness, ${ }^{271}$ for example, the U.C.C. is justified if allocation by negligence is considered a more important objective. And, in practice, since a taker will lnow that he will be protected by following the prudent practices of his business, placing the loss on negligent takers should not unduly restrict transferability.

By providing a single set of rules for all jurisdictions, the Code provides uniformity in an area in which different courts have established many conflicting doctrines. However, there is a real likelihood that varying interpretations of some sections of the Code will reintroduce diversity. For example, courts may introduce variations by their construction of the terms "negligence" and "substantially contributes" in the section placing loss on negligent drawers and payees. ${ }^{272}$ While the omission of a definition of "negligence" is understandable, objection can justifiably be made to the failure to include in the text of the Code some criteria for giving substance to the phrase "substantially contributes."273 Diverse interpretation may also arise in the application of the care which a drawer must take in discovering and reporting forged and altered instruments to his bank, and in application of the Code's time periods. ${ }^{274}$ Again, clarity of statement would have obviated this difficulty. Finally, there is the variation that may arise even within a single jurisdiction from construction of general terms such as "reasonable commercial standards"275 and "reasonable care."276 This, however, is the inevitable penalty for selecting flexible doctrines.

Because of a pronounced favoritism for banks, the Code's negligence sections completely fail to provide uniform treatment for parties behaving similarly. Not only are negligent banks given protection in situations where other parties

269. The Code clearly permits a drawee to recover from a prior party who did not exercise good faith or reasonable commercial care. $\$ 3-418$, note 187 suspr. The section and comments fail to limit the right of recovery to only careful drawees. It is possible, however, that courts will read the common law prohibition against negligent drawee's recovering into the U.C.C. See notes 44,158 supra.

270. U.C.C. $\$ 3-405$, note 246 supra; $\$ 3-406$, note 224 supra; $\$ 4-106(1)$, note 233 supra.

271. U.C.C. $\$ 3-302(1)$ (b), note 1SS supra, operating through $\$ \$ 3-406,3-407$.

272. U.C.C. \& $3-406$, note 224 sippra.

273. The comments fill the void to some extent by giving some examples including negligent drawing of an instrument and negligence in protecting a signature stamp. U.C.C. \$ 3-406, Comments 1,7 .

274. U.C.C. $\$ 4406$, note 233 sispra; and discussion in text at notes 237 at seq. suspra.

275. U.C.C. $\$ 3-302(1)(\mathrm{b})$, note $18 S$ stipra.

276. U.C.C. $\$ 4-406$ (1) (a), note 233 supra. 
would be held liable, ${ }^{277}$ but they are protected by the ability to impose agreements limiting a drawer's right to recover to ten days ${ }^{278}$ or by an absolute statute of limitations against actions by the drawer. ${ }^{270}$ The latter is justified by the Code as desirable to put at rest transactions arising from checks. ${ }^{280}$ But until the ordinary state statute of limitations applying to actions on negotiable instruments has run, the drawer and drawee are liable on an action by the payee ;281 and prior parties are liable not only to the payee, ${ }^{282}$ but also to the drawee ${ }^{280}$ and the drawer. ${ }^{284}$ If there should be a policy "in favor of the mechanical termination of the liability of the bank," it equally applies to the termination of liability of all parties to the check. The only justifiable treatment of this problem would be a shortened statute of limitations on all actions arising from the forgery whether the actions are based on the instrument or on the underlying transactions. ${ }^{285}$

Allocation Modified by Availability of Defense. The Code continues existing practice of permitting the peculiar availability of defenses to modify loss allocation. Clearly, the Code permits the drawee bank to waive the drawer's lack of timely notice of forgery and then to proceed against prior parties who cannot assert the negligence against the drawee. ${ }^{280}$ Similarly, the ability of a collecting bank to waive the defense of payment by the drawee on a forged

277. U.C.C. \$ 4-401(2) (a), note 214 supra; and discussion in text at notes 264-5 supra.

278. U.C.C. § 4-103; see notes 234-5 supra.

279. U.C.C. \$ 4-406, note 233 supra.

280. The Comment to U.C.C. § $4-406$ says about the statute limiting recovery on forged and aitered checks: "It is based ... upon the obvious desirability of terminating bank transactions after a relatively short period. ..." On the cut off statute for forged endorsements the Comment remarks: "The three year absolute time limit on the discovery of forged endorsements should be ample, because in the great preponderance of cases the customer will learn of the forged endorsements within this time and if in any exceptional case he does not, the balance in favor of a mechanical termination of the liability of the bank outweighs what few residuary risks the customer may still have." U.C.C. \& 4-406, Comments 6,8 .

281. On the ability of the payee to sue the drawer see cases cited notes, 10, 23 supra. The right of the payee to sue the drawee in conversion under the U.C.C. is settled, U.C.C. § 3-419(1) (c), although under common law there was diversity of viewpoint. See note 24 supra.

282. The payee has recovered against the collecting bank in actions in conversion up to 7 years. See note 195 supra. Under the U.C.C. the payee's right against a collecting bank who acts with good faith and reasonable commercial care is limited to the amount of any proceeds remaining in its hands. U.C.C. \& 3-419(3).

283. The drawee may sue even though it has waived the statutory period voluntarily. See note 67 sipra.

284. Beyond the statutory period the drawer may have an action against prior parties. See notes 71,72 supra.

285. A drawer might have to refund money to a payee without his usual right of recovery against the bank. This contingency is admitted by the draftsmen. U.C.C. \& 4-406, Comment 8, note 280 supra.

286. U.C.C. \$ $4-406$, note 233 supra. 
instrument and then recover from prior parties who are unable to shift loss still exists. ${ }^{287}$ And as previously pointed out, this waiver may even be hardened into firm practice under the Code by agreements between banks always to refund payment on forged instruments. An additional possibility of waiver may occur when a negligent drawer, whose negligence substantially contributed to the loss, persuades his bank to recredit his account and to fall back on prior parties.28s The Code also continues the practice of preventing negligence pleas by certain parties even when the negligent person is before the court. Of course, in so far as the Code does retain the existing law's peculiar availability of defenses, the criticism of existing law is equally apropos for the Code.

Additionally, the U.C.C. has introduced a peculiar change in the ability of the payee to sue other parties. While it affirms the right of the payee to sue the drawee bank in conversion for paying on a forged endorsement, ${ }^{293}$ it gives a collecting bank who exercises reasonable care a defense against the payee for the amount of any proceeds not remaining in the bank's hands.93 Since the collecting bank is not given this defense against the drawee, if the payee succeeds in collecting from the drawee, the drawee will be able to recover the full amount of the instrument from the collecting bank.. ${ }^{201}$ Thus, this change seems only to create needless circuity of action.

While the Code has been subject to severe criticism for failure to secure desirable objectives, actually many of the Code's major defects stem from Article 4: the sections on the bank collection process. True, the Code does retain a basic structure of allocation geared to the type of forgery, and the peculiar availability of defenses. In this, it possesses many of the defects of existing law. The imposition of Article 4, however, makes the Code even less desirable than existing law. The variation introduced by the agreements

287. See text at notes 200-6 supra.

28S. The text of the Code supports this possibility since only the "nerson who by his negligence substantiaily contributes to a material alteration ... or to the maling of an unauthorized signature is precluded from asserting the alteration or lacl: of authority. . . U.C.C. \& 3-406. Courts have interpreted somewhat similar statutes prescribing a statutory time limit within which the drawer must give his bank notice of forgery to allow the drawee to waive and fall back on prior parties. See cases cited note 67 supra. However such an interpretation would defeat the underlying policy of the section which is that the drawer owes a duty of care to all parties who may have come in contact with the instrument. See note 221 supra. Thus, the bank should not be permitted to waive a defense designed to protect others.

289. U.C.C. $\$ 3-419$ (1) (c). The drawee's liability is limited to the face amount of the instrument. U.C.C. $\$ 3-419(2)$.

290. U.C.C. $\$ 3-419(3)$; see note $2 \$ 2$ surra.

291. Recovery is under the warranty given by the collecting bank to the drawee bant: that it has good title to the item. U.C.C. $\$+207$ (1) (a). 
section is the worst offender. And the Article also includes the sections that permit a drawee to recover when it only exercises good faith in situations where others must be free from negligence in order to bring suit. Thus the elimination of Article 4 would unquestionably make the Code a more acceptable substitute for existing law-especially in light of the Code's improved negligence sections. However, while the Code without Article 4 might offer some improvement over existing law, it nevertheless remains a wholly inadequate vehicle for allocating forgery losses.

\section{Suggested Proposals for Reform}

One of the most effective ways of striking at the problem of losses from check forgeries is to reduce the possibility of successful forgery. To accomplish this purpose, it is proposed that a new form of drawing checks-"restrictive drawing"-be utilized. A check restrictively drawn would be an instrt1ment drawn to the payee for deposit only at his bank. Such a check, whether stolen from the mails or taken by an impostor, would be of no value to the forger unless he had an account in the name of the payee at the payee's bank. Not only would it be unlikely that the forger would possess such an account, but should he attempt to open one, the coincidence of two parties with identical names at the same bank would certainly subject the forger to close scrutiny and enhance the likelihood of his being discovered. It is true that in a "fictitious payee" situation the forger may open an account in the name of the fictitious payee. This possibility of circumventing the protection of the restrictively drawn check can be minimized by requiring banks to exercise some care in opening strangers' accounts. In any event, restrictive drawing, while a wide departure from existing practice, is not revolutionary in negotiable instruments law. Similar checks are negotiable instruments in England today. ${ }^{202}$ And analogies to restrictive drawings are found in the currently acceptable restrictive endorsement.

Restrictive drawing of course thwarts transferability of the check. Payees would be unable to use restrictively drawn checks as transfer devices to obtain money at places other than the specified bank. However, a large number of checks do circulate simply as payment devices between businesses, and for these checks, restrictive drawing would provide increased protection without impairing the check's function. At the same time, the transferability of the check in other situations can be readily preserved by leaving to the payee the option of whether or not he desires checks to be restrictively dratwn. From a practical standpoint, the entire scheme can be facilitated if on invoices or requests for government checks, for example, the payee desiring restrictive drawings would indicate the name of the bank in which he holds a checking or savings account. However, granting the payee the option to refuse the

292. Chatarers, Bifls of Exchange $\$ 82$ (9th ed. 1927); see, c.g., Underwood Lttl v. Bank of Liverpool, [1924] 1 K.B. 775; National Bank v. Silke, [1891] 1 Q.B. 435 (C.A). 
restrictive drawing does not imply that he should sustain all losses subsequently occurring from forgery of ordinary checks; this would be penalizing parties who wish to take advantage of the highly useful characteristic of checks making them transfer devices for payment. Rather, the payee's liability should be determined by considering all the objectives governing allocation of forgery losses.

Although restrictive drawing can operate to eliminate some possible furgeries, it nevertheless leaves many possibilities for forgery untouched. Restrictive drawings cannot prevent forged drawer's signatures, for example, nor alterations on checks made by the payee himself. And of course, retaining the check as a useful transfer device by preserving the payee's option to elect payment by ordinary check, continues the existing hazards of forgery: Thus, even with restrictive drawings, forgeries will undoubtedly occur. 10 allocate losses from these forgeries, additional proposals for reform are offered.

Proposals for reform of existing law of forgery are offered not with an eje to doctrinal nicety, but rather with a view of obtaining sensible and equitable objectives in allocating loss. Early decisions establishing the forged check and forged endorsement rules compartmentalized subsequent allocation into doctrines based on type of forgery. But the assumptions underlying the dichotomy have seldom been questioned. Clearly, allocating according to type of forgery and the peculiar availability of defenses developed within these rules should be cast aside, since they serve only to frustrate intelligent allocation. At the same time, the continental law, which allows a forger to pass good title, does not offer an acceptable solution. By placing risk on the drawer and payee, it has perhaps precluded development of a widely used check system and the application of negligence doctrines. Nor would exclusive adherence to the forged check or forged endorsement rule be satisfactory. The forged endorsement rule, by placing loss on takers, defeats transferability and efficient risls distribution and may also frustrate allocation according to negligence. The forged check rule does promote tranisferability and better risk distrilution, liut it is probably most removed from gearing loss to negligence.

Initially, since objectives may conflict in particular cases, a priority of objectives must be established. The following proposals embody a preference for placing the loss on a negligent party over the goals of most efficient risl distribution and promotion of transferability where a conflict exists. This preference is based on a belief that potential liability for breach of commercial standards will help encourage better business practices, and that fairness dictates that a person whose conduct contributed to a loss should sustain that loss. 283

The goal of placing loss on negligent parties can be secured by establishing a warranty, given by all parties who deal with a check, that they have exercised reasonable care according to the standards of the business or activity in which they are engaged in their dealings with the check. This warranty would run

293. See notes 92,93 supra. 
to all other parties who come in contact with the check. Breach of the warranty would subject a party to liability for any loss arising from a forgery; and no party who has breached the warranty would be able successfully to sue another. ${ }^{294}$ As a result of this suggestion, whenever negligence contributes to loss, that loss will ultimately fall on the negligent party.

In the event that no party has been negligent in dealing with the check or that the drawee and another party have both been negligent, loss allocation should be geared to the promotion of transferability and most efficient risk distribution. Since transferability can be equally served by holding either drawer or drawee liable, and since the most desirable risk distribution is accomplished by placing loss on the drawee, loss which occurs in the absence of any negligence or in the combined negligence of drawee and others should be allocated to the drawee. As a result, in these situations, loss becomes one of the costs of utilizing checks and is paid for ratably by those who draw checks. ${ }^{295}$

Uniform treatment of parties is also secured by these suggested changes. Abolition of the rules relating to the type of forgery insures that parties who act with similar regard to business standards will be subject to the same potentiality of loss. And parenthetically, this provides a boost for transferability, since parties who take checks will know that they are able to free themselves from loss by following standard rules. Uniform restlts in different jurisdictions rest on universal adoption of the proposals and the subsecutuent consistency of courts in construing reasonable standards of care.

The proposed reforms are an attempt to achieve a balance between the desire to simplify litigation through the use of automatic doctrines and the desire to maintain a certain degree of flexibility. In the absence of negligence, certainty as to liability prevails, and thus enables predictability and out of court settlements. Additionally, certainty may be promoted by a short statute of limitations placing an end to potential liability on a check and all transactions underlying it. However, in contrast to current law and the U.C.C., the statute should end liability for all parties, for the certainty is equally desirable for all who deal with checks. The use of negligence doctrines does preclude complete predictability and complicates litigation until limitations have run. But at the same time, it permits flexibility of standards concomitant with changing business practices. Moreover, while trials would of course require a showing of lack of due care, standards providing some degree of certainty may shortly crystallize either through judicial interpretation or statutory enactment. In the event that the latter option is preferred, suggestions for standards geared to existing business practices are set forth in the appendix.

294. Others have suggested that a comparative negligence approach including loss splitting provisions be studied as a solution. See Notes, 27 IND. L.J. 561 (1952), 14 U. of ChI. L. Rev. 705, 709 (1947) ; cf. Gregory, Legislative Loss Distrubutrion iN NegliGENCE ACTIONS 154 (1936).

295. See text at notes $87-90$ supra. 


\section{APPENDIX A}

\section{STATUTE FOR CHECKS WITH UNAUTHORIZED SIGNATURES AND MATERIAL ALTERATIONS}

\section{Section 1. Warkanties on Dealing with Checks}

(1) Any owner of a checking account, drawer, payee, collecting bank, and any other party who transfers a check warrants to all prudent parties who have been injured by his conduct that he has been prudent in dealing with the check.

(2) The drawee of the check warrants to all other parties that he has been prudent in dealing with the check.

\section{Section 2. Limitation on Actrons}

An unauthorized signature or material alteration cannot be asserted in any action on a check or an underlying obligation for which a check has been issued against any party who has not been notified of the unauthorized signature or material alteration within eighteen months after the drawee has paid the check.

\section{Section 3. Definitions}

In this Statute:

(1) "prudent" conduct includes good faith and either the exercise of reasonable commercial standards of the business in which the party may be engaged, or if the party is not in any business, freedom from negligence;

(2) "have been injured" refers to an injury which was partially or completely caused in fact by conduct;

(3) "unauthorized signature" means a signature made without actual, implied, or apparent authority and includes a forgery;

(4) "material alteration" is an alteration of the instrument which changes the contract of any party to the check in any respect;

(5) "dealings with the check" include all actions which have to do with the issuance, delivery, receipt, transfer, and payment of checks including the hiring and supervision of any employees engaged in these transactions.

\section{APPENDIX B}

Standards OF Conduct*

The drawer of a check must:

(1) Draw the checks in ink or with a check writing machine.

(2) Correctly execute future instruments after notification by the bank

*The standards are in accord with many of those suggested by banlis. See Arserscair Bankers Assoctation, Bank Tellers Do's and Don't's (1952); Intuig Trust Conpany, Safeguards Agatnst Forgeries (1944). The standards are also derived from case law, although some case law criticized in the text has been disregarded. 
that instruments which he has drawn might be easily altered because too much space is left on the line on which the amount is written.

(3) Mail checks to the correct address of the payee or his authorized agent.

(4) Ascertain the correct identity of the payee to whom the check is drawn and delivered.

(5) After having twice been instructed by the bank: (a) balance his account on the receipt of his statement; and (b) exercise reasonable care to discover and report to the bank any forged instrument or instrument whose sum has been altered.

(6) The drawer may delegate any of these duties to his employees and is not to be considered negligent or barred from recovery if he: (a) establishes regular procedures which meet the approval of his bank for the drawing, distribution, and accounting of returned checks, and (b) discovers the existence of the dishonest employee after unexplainable increases of cost have come to his attention.

The drawee of a check must:

(1) Examine the authenticity of the signature of the drawer of the check, with a second examination required for all checks of $\$ 1,000$ and over.

(2) Examine the check for any irregularities in the chain of endorsement, or for any alterations.

(3) Notify the drawer of any checks which have been drawn in a careless manner which would facilitate fraudulent alterations.

(4) Explain to the drawer his obligation to balance his account and examine returned checks. This explanation should be given at the time the account is opened and repeated when the first statement is given to the drawer.

(5) Identify a party who presents a check for collection at least by examining documents which contain the name, description, and signature of the presenter and by comparing the signature of an endorsement made in the presence of the drawee with that on the documents.

The recipient of the funds from the drawee or taker from a prior holder must:

(1) Identify the party from whom he receives the check, at least by examining documents which contain his name, description, and signature, and by comparing the signature with an endorsement made in the recipient's presence. The recipient must indicate on the check a reference to documents examined.

(2) Be free from knowledge of the invalid character of the check at the time the instrument is further negotiated or is presented for payment.

The payee or true owner must:

(1) Not place a blank endorsement on the check until he is ready to transfer it.

(2) If checks are received or deposited by employees, establish regular practices which meet the approval of his bank for handling the checks. 


\section{APPENDIX C}

\section{CROSS REFERENCE TABLE TO CODE SECTIONS}

Code Section

1-102. Purposes: Rules of Construction

3-201. Transfer: Right to Endorsement

3-302. Holder in Due Course

3-405. Impostors; Signature in Name of Payee

3-405. Negligence Contributing to Alteration or Unauthorized Signature
Discussed in Text at Notes

$185^{*}, 186^{*}, 203,231$

$189 \%, 230,252,253$

$188 * 211,232,252$,

$254,271, \quad 275$

$246 \%, 247,248,249$,

250, 261, 262, 263, 270

$224 \div, 229,231,254$,

255. 264, 269, 270,

$271,272,273,288$

\begin{tabular}{|c|c|c|}
\hline 3-407. Alteration & $211 *, 215$ & $265,271,277$ \\
\hline $\begin{array}{l}\text { 3-417. Warranties on Presentment or } \\
\text { Transfer }\end{array}$ & $\begin{array}{ll}187, & 190, \\
201, & 207, \\
210, & 212, \\
220, & 222,\end{array}$ & $\begin{array}{l}192, \quad 195, \\
208,209, \\
213.218, \\
241,243, \quad 259\end{array}$ \\
\hline $\begin{array}{l}\text { 3-418. Finality of Payment or Accept- } \\
\text { ance }\end{array}$ & $\begin{array}{l}187 \%, 190 \\
217,242,\end{array}$ & $\begin{array}{l}198,201, \\
260\end{array}$ \\
\hline 3-419. Conversion of Instrument & 281,282 , & 289 \\
\hline 4103. Variation by Agreement & $\begin{array}{l}200 \div, 203, \\
205,221,\end{array}$ & $\begin{array}{l}204 * 205 \\
234,235,278\end{array}$ \\
\hline $\begin{array}{l}\text { 4207. Warranties of Customer and Col- } \\
\text { lecting Bank on Transfer or Presen- } \\
\text { tation of Items }\end{array}$ & $\begin{array}{l}192, \quad 195 \\
212, \\
254,259\end{array}$ & $\begin{array}{l}208,210 \\
223, \\
2391\end{array}$ \\
\hline
\end{tabular}

4-208. When Bank Extending Credit for 260

Item has Security Interest

4209. When Bank Gives Value for Pur- 260

poses of Holder in Due Course

* Marks notes with substantial quotations from the U.C.C. 
Code Section

4-401. When Bank May Charge Customer's Account

4-406. Customer's Duty to Discover and Report Unauthorized Signature or Alteration
Discussed in Text at Notes

214*, 251, 252, 264, $265,267,277$

233*, 254, 255, 256,

$257,258,266,268$,

$270,274,276,279$,

$280,285, \quad 286$

4-407. Payor Bank's Right to Subroga- 196*, 220, tion on Improper Payment

*Marks notes with substantial quotations from the U.C.C. 